\title{
A REMUNERAÇÃO DO PARTICULAR NA EXECUÇÃO DE ATIVIDADES PÚBLICAS
}

TESE DE DOUTORADO

Orientadora: Professora Titular Dra. ODETE MEDAUAR

FACULDADE DE DIREITO DA UNIVERSIDADE DE SÃO PAULO

$$
\text { SÃO PAULO }
$$

2014 


\section{A REMUNERAÇÃO DO PARTICULAR}

\section{NA EXECUÇÃO DE ATIVIDADES PÚBLICAS}

Tese de Doutorado apresentada à Faculdade de Direito da Universidade de São Paulo, como parte dos requisitos para obtenção do título de Doutor em Direito do Estado. 


\section{A REMUNERAÇÃO DO PARTICULAR NA EXECUÇÃO DE ATIVIDADES PÚBLICAS}

Tese de Doutorado apresentada à Faculdade de Direito da Universidade de São Paulo, como parte dos requisitos para obtenção do título de Doutor em Direito do Estado.

Aprovada em de de 201

BANCA EXAMINADORA

Profa. ODETE MEDAUAR

$\operatorname{Prof}(\mathrm{a})$.

$\operatorname{Prof}(\mathrm{a})$.
$\operatorname{Prof}(a)$.

Prof(a). 
À minha esposa, Cristina Alvarez Martinez Gerona Miguel, com meu amor e gratidão. 


\section{AGRADECIMENTOS}

O sonho de estudar nas "Arcadas" não teria se tornado realidade sem a ajuda de ODETE MEDAUAR. Professora por vocação. Mestre a quem devo minha eterna gratidão pelas oportunidades, pelas lições e pelo companheirismo.

A caminhada não teria sido tão prazerosa não fossem as aulas de dois grandes professores: Floriano de Azevedo Marques Neto e Fernando Dias Menezes de Almeida. Foram as considerações destes dois notáveis juristas que tornaram mais inteligível a presente tese.

Aos meus pais, que me incentivam e apoiam desde sempre, fica a lembrança de uma infância bem vivida, uma adolescência bem curtida e uma vida adulta bem definida.

À minha irmã, minha certeza de que "missão dada é missão cumprida".

À toda brilhante equipe de profissionais da Advocacia Luiz Felipe, meu escritório de advocacia, pela competência e pela compreensão pelos momentos de ausência e mau humor.

Aos meus amigos de mestrado e doutorado pelas discussões acadêmicas, boa parte delas refletidas em pensamentos exarados no presente trabalho.

A todos aqueles que, direta ou indiretamente, colaboraram para a conclusão de mais esta fase de minha vida acadêmica. 
"Só o bem neste mundo é durável, e o bem, politicamente, é todo justiça e liberdade, formas soberanas da autoridade e do direito, da inteligência e do progresso."

Rui Barbosa 


\section{RESUMO}

Busca o presente trabalho apresentar ao leitor as diversas formas pelas quais poderá o particular, executor de atividade pública, se remunerar. Com o desenvolvimento do direito administrativo novos modelos contratuais permitiram a adoção de modais remuneratórios diversos, aptos a viabilizar delegações antes inconcebíveis, quando idealizadas sob a ótica do regime tarifário.

O estudo se inicia com a delimitação da noção de remuneração, a definição de quem são os particulares e do que é atividade pública. Após a identificação de quais destas atividades são passíveis de delegação à execução privada, a problemática da remuneração é tratada perante 3 (três) grandes blocos de atuação estatal.

No primeiro bloco são analisadas as especificidades remuneratórias do particular prestador de serviço público. A tarifa (forma tradicional) é colocada em confronto com outras fontes de receitas (alternativas, complementares, acessórias, contraprestações públicas, subsídios). No segundo grande bloco a exploração direta de atividade econômica pelo Estado, tendo como partícipe o particular, é alvo de avaliação. O terceiro bloco se destina à análise da execução de atos de polícia pelo agente privado.

Por fim, novas formas de remuneração são aventadas, demonstrando que são inúmeras as possibilidades para estruturação de delegações de funções estatais. A proposta é, ao final, identificar a existência de um regime jurídico de remuneração do particular que executa atividade pública.

PALAVRAS-CHAVE: 1) remuneração; 2) atividades públicas; 3) regime jurídico remuneratório. 


\begin{abstract}
The present work aims at introducing its reader to the many diverse ways in which the private, executor of public sector activities, may be compensated. With the development of the administrative law new contractual practices have allowed the adoption of various compensating models. They are capable of making feasible delegations that have once been considered inconceivable when idealized by the tax regime concept.
\end{abstract}

The study begins with a delimitation of how to perceive compensation, the definition of who the private is and what public sector activities mean. After identifying which of these activities are susceptible to the delegation of the private sector, the problematic of compensation is discussed before three major blocks of the state.

The first block analyzes the compensatory specifications of the private civil servant. The traditional tax is confronted with other sources of income (alternative, complementary, accessory, public consideration, subsidies). In the second major block the exploration of State economic activity, in which the private sector is a participant, is subject to evaluation.

At last, new compensatory ways are exposed, demonstrating the innumerous possibilities of structuring the delegations of state functions. The proposal is to finally identify the existence of a judicial compensatory regime of the private sector that enforces the public sector activities.

KEYWORDS: $\quad$ 1) compensation; 2) public sector activities; 3) judicial compensatory regime. 


\section{RIASSUNTO}

Cerca il presente lavoro di esporre al lettore le diverse forme per cui potrà il privato, esecutore di attività pubblica, remunerarsi. Con lo sviluppo del diritto amministrativo nuovi modelli contrattuali hanno permesso l'adozione di modali remunerativi diversi, atti a consentire delegazioni prima inconcepibili, quando ideate sotto l'ottica del regime tariffario.

Lo studio si inizia con la delimitazione della nozione di remunerazione, la definizione di chi sono i privati e di cos'è l'attività pubblica. Dopo l'identificazione di qualli di queste attività sono passibili di delegazione all'esecuzione privata, la problematica della remunerazione è trattata da tre grandi blocchi di attuazione statale.

Nel primo blocco sono analizzate le specificità remunerative del privato prestatore di servizio pubblico. La tariffa (forma tradizionale) é messa a confronto con altre fonti di risorse (alternative, complementari, acessorie, controprestazioni pubbliche, sussidi). Nel secondo grande blocco l'esplorazione diretta di attività economica dallo Stato, avendo come partecipe il privato, è bersaglio di valutazione. Il terzo blocco si destina all'analisi dell'esecuzione di atti di politica dall'agente privato.

Infine, nuove forme di remunerazione sono avventate, dimostrando che sono innumeri le possibilità per la strutturazione di delegazioni di funzioni statali. La proposta è, alla fine, identificare l'esistenza di um regime giuridico di remunerazione del privato che esegue attività pubblica.

PAROLE-CHIAVE: $\quad$ 1) remunerazione; 2) attività pubbliche; 3) regime giuridico remunerativo. 


\section{S U M Á R I O}

\section{I-PRÓLOGO}

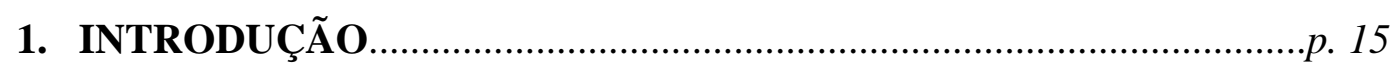

1.1. ABRANGÊNCIA DA NOÇÃO DE REMUNERAÇÃO.................p. 18

1.2. QUEM É O PARTICULAR....................................................... $p .20$

1.3. O QUE É ATIVIDADE PÚBLICA.............................................p. 23

2. ATIVIDAdes PÚBlicas DELEGÁVEIS À EXECUÇão POR

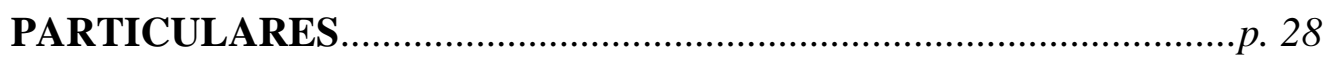

3. A EXPLORAÇÃO ECONÔMICA DE ATIVIDADES TOMADAS COMO

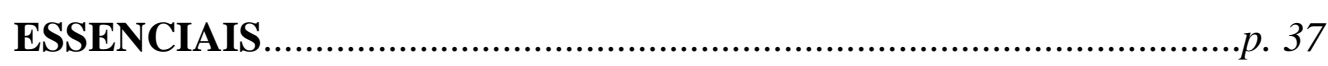

3.1. CONFLITO NATURAL DE INTERESSES ………….................... 37

3.2. OBJETIVO DO DELEGATÁRIO DE ATIVIDADE PÚBLICA - LÓGICA ECONÔMICA p. 39

\section{$\underline{\text { II - BLOCO A - serviço público }}$}

4. ATIVIDADE: SERVIÇO PÚBLICO_................................................... 41

4.1. REGIME REMUNERATÓRIO DO PRESTADOR DE SERVIÇO PÚBLICO p. 43

4.2. SISTEMA USUAL............................................................... p. 45

4.3. A QUESTÃO DA EQUAÇÃO ECONÔMICO-FINANCEIRA DA

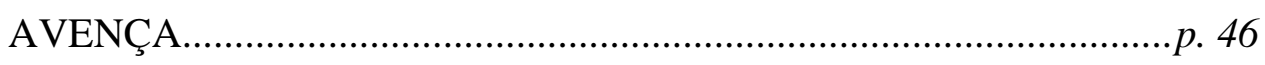

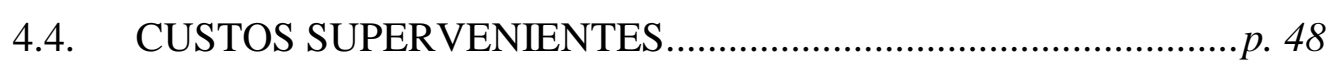

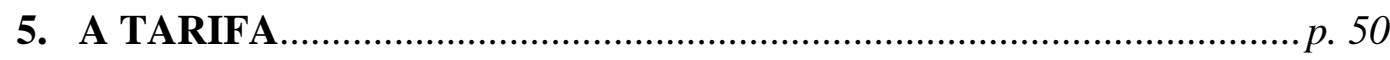




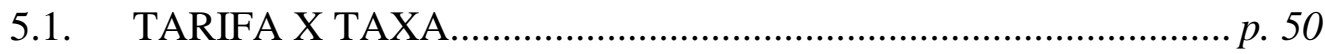

5.2. NATUREZA JURÍDICA........................................................

5.3. TARIFA E LUCRO_............................................................ p. 59

5.4. SISTEMA DE FIXAÇÃO DAS TARIFAS.................................p. 62

5.4.1. Princípio da modicidade tarifária...................................... p. 65

5.4.2. A complexa questão da universalidade do serviço...............p. 67

5.5. REVISÃO E REAJUSTE.......................................................... p. 68

6. RECEITAS SECUNDÁRIAS.......................................................... $p .73$

6.1. QUAIS SÃO (ALTERNATIVAS X COMPLEMENTARES X ACESSÓRIAS X PROJETOS ASSOCIADOS) .................................p. 74

6.2. LEGITIMIDADE DO DELEGATÁRIO EM RECEBÊ-LAS........p. 77

6.3. O IMPACTO SOCIAL ............................................................. $p .80$

6.4. POSSIBILIDADE DE REMUNERAÇÃO DO PARTICULAR EXCLUSIVAMENTE POR ESTE MEIO.........................................p. 81

6.5. FLEXIBILIDADE E REEQUILÍBRIO CONTRATUAL..............p. 83

7. O CASO DAS PARCERIAS PÚBLICO-PRIVADAS........................p. 86

7.1. REGIME MISTO E INVERTIDO DE REMUNERAÇÃO ..........p. 88

7.1.1. A contraprestação pública................................................... 89

7.2. REMUNERAÇÃO EXCLUSIVAMENTE PÚBLICA...................p. 91

7.2.1. Natureza jurídica e suas consequências..............................p. 95

7.3. POSSIBILIDADE DE RECEBIMENTO DE RECURSOS ANTES DA DISPONIBILIZAÇÃO DO SERVIÇO........................................... p. 97

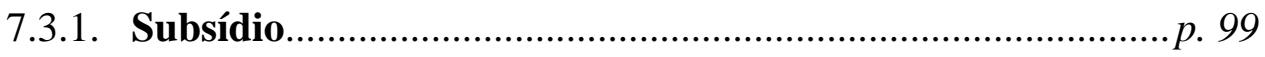

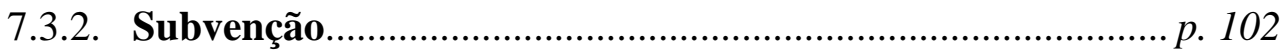

8. OUTROS MODELOS CONTRATUAIS........................................p. 104

8.1. CONTRATOS DO TERCEIRO SETOR.......................................p. 105

8.1.1. Contrato de gestão.................................................................. p. 109 
8.1.2. Termo de parceria......................................................... 111

8.2. CONVÊNIO PÚBLICO...........................................................p. 113

8.2.1. Contrato de repasse.......................................................... p. 119

8.3. CONTRATO DE ARRENDAMENTO.......................................p. 120

8.4. CONTRATO DE FRANQUIA...................................................p. 122

8.5. CONCESSÃO DE RADIODIFUSÃO........................................p. 124

8.6. CONCESSÃO URBANÍSTICA.................................................p. 126

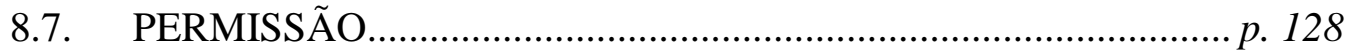

8.8. AUTORIZAÇÃO CONTRATUAL............................................p. 130

9. SISTEMA “S” - SERVIÇOS SOCIAIS AUTÔNOMOS.................... p. 133

10. A CONTRATAÇÃO DE PRESTADOR DE SERVIÇO ..................... 136 10.1. O FENÔMENO DA TERCEIRIZAÇÃO.....................................p. 137

11. PARTICULARES EM COLABORAÇÃO COM O PODER PÚBLICO..................................................................................... 141

11.1. NOTÁRIOS E REGISTRADORES............................................. p. 142

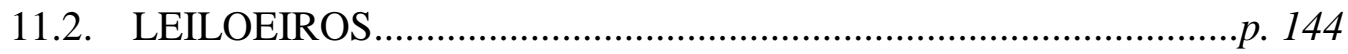

11.3. TRADUTORES E INTÉRPRETES PÚBLICOS ......................... p. 145

\section{III - BLOCO B - exploracão de atividade econômica}

12. ATIVIDADE: EXPLORAÇÃO DIRETA DE ATIVIDADE ECONÔMICA

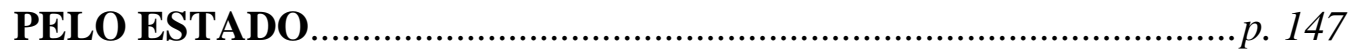

12.1. CAPITALISMO COMO BASE DO MODELO ECONÔMICO.... p. 148

12.2. REQUISITOS PARA ATUAÇÃO DO PARTICULAR NESTE MISTER. .p. 150 
12.3. PARTICULAR COMO AGENTE DE EXECUÇÃO DA ATIVIDADE PÚBLICA p. 153

12.4. A NECESSÁRIA BUSCA PELO LUCRO p. 154

\section{$\underline{\text { IV - BLOCO C - execução de atos de polícia }}$}

13. ATIVIDADE: EXECUÇÃO DE ELEMENTOS DO PODER DE POLÍCIA p. 157

13.1. O PODER DE POLÍCIA COMO COMPETÊNCIA.......................p. 157

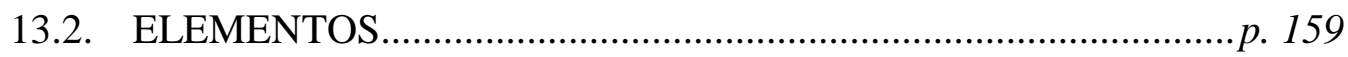

13.3. EXECUÇÃO POR PARTICULAR................................................ 160

13.4. FORMAS DE REMUNERAÇÃO.................................................. 162

\section{$\underline{\text { V-EPÍLOGO }}$}

14. NOVAS FORMAS DE REMUNERAÇÃO........................................ 168

14.1. RECURSOS ADVINDOS DAS GARANTIAS NAS PARCERIAS

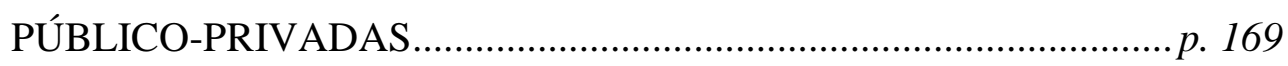

14.2. A EXPECTATIVA DE RECEITA FUTURA.................................. 170

14.3. GESTÃO DE CAPITAL.............................................................. 172

14.4. POTENCIAL ECONÔMICO GERADO PELA CONSTRUÇÃO DA INFRAESTRUTURA................................................................... 173

14.5. COMPARTILHAMENTO DE INFRAESTRUTURA.....................p. 175

14.6. EXPOSIÇÃO DA MARCA........................................................ 178

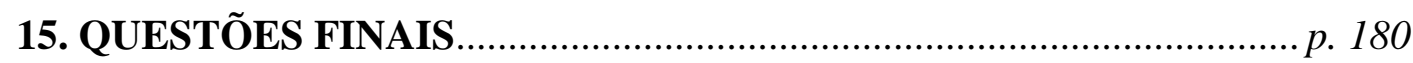

15.1. GANHOS DECORRENTES DE ALTERAÇÕES FACTUAIS NO CURSO DO CONTRATO.................................................................... p. 180

15.2. PROCEDIMENTO DE MANIFESTAÇÃO DE INTERESSE.......p. 182 

15.2.1. Possibilidade de desenhos financeiros ainda não

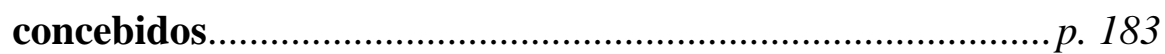

15.3. A REMUNERAÇÃO DAS GRATUIDADES............................. p. 184

16. EM BUSCA DE UM REGIME JURÍDICO REMUNERATÓRIO......p. 187 16.1. TRAÇOS COMUNS A TODA E QUALQUER EXECUÇÃO DE ATIVIDADE PÚBLICA POR PARTICULAR ................................... $p .188$

16.2. ASPECTOS IMPRESCINDÍVEIS AO SISTEMA
REMUNERATÓRIO.................................................................. 190

16.3. REGRA GERAL DE REMUNERAÇÃO......................................p. 193

16.4. A IDENTIDADE DE UM SISTEMA........................................ p. 196

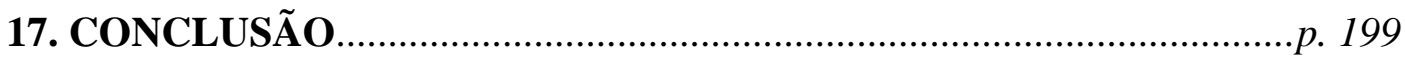

18. BIBLIOGRAFIA ....................................................................... p. 204 


\section{INTRODUÇÃO}

1.1. Abrangência da noção de remuneração; 1.2 . Quem é o particular; 1.3. O que é atividade pública.

O mundo contemporâneo depara-se com um fenômeno que vem ganhando força dia após dia. A globalização, tomada em seu mais amplo sentido, tem acarretado mudanças em todo o planeta. As economias deixaram de ser independentes, formando hoje um complexo e sensível conjunto de elementos interligados de produção, distribuição e consumo de bens e serviços. A cultura das nações se aproxima com a polarização dos idiomas. Os sistemas econômicos se identificam, num momento em que os poucos países ainda ditos socialistas se arrastam à beira do colapso de seus Estados. O capital impõe um ritmo frenético de evolução social, impulsionada pelos avanços tecnológicos que "tornam o mundo cada vez menor".

Neste cenário de intensa globalização é exponencial o crescimento da complexidade das atividades particulares. Tais atividades, hoje realizadas em grande parte 
do planeta num regime de livre concorrência, acabam por impor aos Estados a necessidade de regulação, sob pena de permitir a grandes grupos privados a exploração e possível domínio de setores, produtos e serviços de extrema importância à vida em sociedade.

Surge, portanto, a necessidade dos Estados se adequarem rapidamente a variados contextos. Novas demandas socioeconômicas reclamam outras formas de atuação do Poder Público. Antes adstritos apenas à prestação dos denominados "serviços públicos clássicos", hoje afloram atividades diversas que impõem a revisão de conceitos tradicionais, amoldando a atuação administrativa aos desafios do novo milênio.

O Estado atual é deveras mais complexo do que o de décadas e séculos passados. Sua atuação encontra-se em franca expansão, englobando vários flancos antes alheios à sua competência. Neste sentido são as lições de Alexandre Santos de Aragão ${ }^{1}$ :

No início do século XX, o Estado deixou de ser monoclasse para ser pluriclasse em razão do advento do voto universal (não mais censitário como no Estado liberal). Com isso, para atender a todas as demandas dos legitimados a votar e, portanto, titulares de poder político, foram bastante aumentadas as funções exercidas pelo Estado, passando a intervir mais intensamente na vida social e econômica (tinha de dar conta dos interesses de todas as classes que podiam votar, não mais circunscritas apenas à burguesia).

O contexto acima descrito delineia uma nova forma de pressão social: a busca por maior respeito e proteção das liberdades individuais, da igualdade entre os indivíduos e do bem comum. Os Estados, que antes centralizavam as diversas atividades públicas (ocasionando o inchaço da máquina administrativa e, consequentemente, tornando ineficiente sua execução), foram obrigados, num processo iniciado no final da década de 70 do século passado, a lançarem-se num amplo programa de privatização.

No Brasil, hoje um dos principais atores econômicos mundiais, o processo não foi diferente. Diminuiu-se significativamente a intervenção do Estado no domínio econômico, desmonopolizaram-se as atividades econômicas, venderam-se ações de

\footnotetext{
${ }^{1}$ ARAGÃO, Alexandre Santos de. Curso de direito administrativo. Rio de Janeiro: Forense, 2012, p. 7.
} 
empresas estatais ao setor privado (desestatização), ampliando a participação e colaboração do particular na gestão das coisas públicas.

Assim, as privatizações (elogiadas por uns, demonizadas por outros) significaram a tentativa de redefinir o Estado, substituindo seus antigos por novos objetivos através do fortalecimento das liberdades econômicas das pessoas. Nas lições de Odete Medauar'

\begin{abstract}
Vários fatores explicariam a privatização de empresas estatais e a transferência de serviços públicos à execução de particulares: financeiros, para conter o déficit público e reduzir despesas; jurídicos, ante o peso dos controles centrais; políticos - nos governos de inspiração neoliberal, para reforçar o setor privado, e nos de inspiração socialista, como revisão de dogmas políticos. De modo mais amplo, menciona-se a privatização como uma das respostas à crise do Welfare State.
\end{abstract}

Com as privatizações novos instrumentos jurídicos surgiram, dando ensejo à intensificação da delegação de atividades públicas à iniciativa privada: concessões (comuns), permissões, autorizações. Mais recentemente, frente à sensível carência de recursos públicos para implementação de infraestrutura capaz de suportar a continuidade do desenvolvimento da economia, uma nova forma de delegação de atividades públicas à exploração privada surgiu: as denominadas "Parcerias Público-Privadas", que vieram no intuito de alargar ainda mais o campo de atuação dos particulares em setores antes exclusivos do Estado. Com elas, diversas atividades (não necessariamente atreladas à noção de serviço público) têm sido transferidas à prestação pelos particulares.

O fato é que, ao entregar a execução de uma atividade qualquer a um particular, o Estado assume o ônus de pagá-lo por esta prestação; ou, visando sua remuneração, deve permitir a obtenção de uma (ou algumas) fonte de recursos, preferencialmente decorrente do próprio negócio, sob pena de, fugindo da lógica capitalista, tornar impossível sua vontade.

\footnotetext{
${ }^{2}$ MEDAUAR, Odete. O direito administrativo em evolução. 2. Ed. São Paulo: RT, 2003, p. 249.
} 
O objetivo deste estudo é, portanto, analisar as diversas formas pelas quais um particular, ao executar atividades públicas, poderá se remunerar. Provavelmente nem todas as possibilidades serão aventadas, pois frente às novas modalidades de atuação privada, novas formas de remuneração afloram.

Adiante serão traçadas as premissas que nortearão o presente trabalho. Serão estabelecidos os limites de abrangência de aspectos essenciais relacionados ao tema da tese: o que será considerado remuneração; quem é o particular; o que é atividade pública. Nosso intuito, ao final do estudo, é responder a pergunta: existe um regime jurídico próprio de remuneração dos particulares executores de atividades públicas?

\subsection{ABRANGÊNCIA DA NOÇÃO DE REMUNERAÇÃO}

Ao se falar em remuneração é natural que venha imediatamente à mente a ideia de dinheiro. Um prêmio, uma recompensa por um serviço ou um favor prestado. Normalmente se imagina uma gratificação em espécie, tão logo o serviço tenha sido realizado.

Contudo, nem sempre é assim. A pessoa que faz jus à remuneração pode se dar por satisfeita ao receber algum objeto em troca de seus serviços, em deixar de cumprir dada obrigação ou mesmo em usufruir de alguma vantagem oferecida pelo seu devedor. Muitas são as formas de se remunerar uma atividade. Por vezes a somatória de algumas delas pode dar azo à quitação de um débito.

No caso da execução de atividades públicas, as espécies remuneratórias aumentam exponencialmente. Não é factível listar todas as modalidades viáveis, pois, para cada situação, novas formas podem ser aventadas. É razoável partir do pressuposto de que 
todas as potencialidades econômicas da atividade podem ser exploradas como formas de remuneração. Este raciocínio decorre da intelecção do princípio da eficiência, como apontado por Rafael Wallbach Schwind ${ }^{3}$ :

\begin{abstract}
Conforme destaca Marçal Justen Filho, uma das mais significativas inovações na exploração de serviços públicos diz respeito justamente à apropriação de ganhos econômicos derivados de oportunidades acessórias ou secundárias. Trata-se aqui de derivação direta do postulado da eficiência, que propugna a exploração dos empreendimentos por todos os seus ângulos possíveis e economicamente relevantes, como forma de melhorar a qualidade do serviço e reduzir a necessidade de outras fontes de recursos.

(sem ênfase no original)
\end{abstract}

Vale também trazer à discussão a mudança de paradigma que as relações Poder Público/iniciativa privada têm sofrido nos últimos anos. Antes adstritos à ideia de oposição de interesses, hoje os pactos entre Administração e particulares se assemelham mais a parcerias entre partes, em prol de um objetivo comum. Por certo que em alguns aspectos (principalmente financeiros) aparenta existir um "conflito de interesses". Todavia, na maior parte de uma relação contratual os propósitos são os mesmos. Essa transformação, que nas concessões comuns, por exemplo, passou do modelo de transferência integral dos riscos da atividade concedida ao concessionário para o seu compartilhamento, tornou hoje viáveis novas formas de remuneração dos particulares na execução de atividades públicas.

Vide os subsídios estatais ${ }^{4}$, que se tornaram necessários para a concretização de algumas concessões cujas receitas possivelmente extraíveis da própria atividade não eram suficientes para cobrir os custos de sua operação. Neste sentido são as lições de Vitor Rhein Schirato ${ }^{5}$ :

A necessidade de subsídios tarifários não é distante. Muito ao contrário, é bastante corriqueira, sobretudo em um país com alto déficit de infraestrutura como o Brasil. Muitas vezes, a prestação de um determinado serviço público não é viável por si só em sua integralidade ou com relação a parcela dos usuários, sendo necessária a criação de mecanismos de subsídios

\footnotetext{
${ }^{3}$ SCHWIND, Rafael Wallbach. Remuneração do concessionário: concessões comuns e parcerias públicoprivadas. Belo Horizonte: Fórum, 2010, p. 32.

${ }^{4}$ O Capítulo 7, item 7.3.1., trata especificamente dos subsídios, suas espécies e particularidades.

${ }^{5}$ SCHIRATO, Vitor Rhein. Livre iniciativa nos serviços públicos. Belo Horizonte: Fórum, 2012, p. 263.
} 
públicos para possibilitar ou a própria prestação dos serviços, ou a sua fruição por parcela da população.

Por fim, com o advento da Lei Federal $n^{\circ}$. 11.079/2004, que instituiu as parcerias público-privadas, contraprestações pagas diretamente pelo Poder Concedente também passaram a ser formas viáveis de remuneração. Como adiante será demonstrado, não se confundem com os subsídios, compondo outra categoria remuneratória.

Portanto, no intuito de sintetizar a noção de remuneração, podemos afirmar se tratar dos benefícios de qualquer natureza extraíveis de toda e qualquer potencialidade econômica da atividade explorada, bem como subsídios e contraprestações, desde que tendentes à viabilidade de sua prestação.

\subsection{QUEM É O PARTICULAR}

Traçada a diretriz acerca do que adotaremos por remuneração, cumpre determinar, com clareza, quem será seu alvo. Em outras palavras, identificar quem faz jus a recebê-la, ou seja, quem executa atividades públicas, quando não o faz o próprio Estado (em seu sentido amplo).

A primeira definição a se adotar é a decorrente de exclusão: particular é todo aquele que não é Poder Público. Tal raciocínio remete à conclusão de que particular são todos os outros que não a Administração Pública. Desta forma, estar-se-á a afastar da definição não só a Administração Direta, mas também as entidades componentes da Administração indireta: autarquias, fundações públicas ${ }^{6}$, empresas públicas, sociedades de

\footnotetext{
${ }^{6}$ Nas lições de Odete Medauar, "no tocante às entidades componentes da Administração indireta, a redação de alguns dispositivos da Constituição de 1988 ensejou entendimento diverso do que dispõe a atual redação do Dec.-lei 200/67, em virtude de usarem a expressão "administração direta e indireta, incluídas as fundações instituídas e mantidas pelo Poder Público” (por exemplo, art. 71, inc. III). De acordo com essa corrente,
} 
economia mista e consórcios públicos, estes últimos desde que possuam personalidade jurídica de direito público e se constituam em associação pública ${ }^{7}$.

Mas, apesar de válida, tal distinção ainda mantém ampla a noção daquilo que adotaremos como particular executor de atividade pública. Um segundo critério leva em consideração não quem executa a atividade, mas sim qual atividade executa. Nesta linha, o importante é saber o que é atividade pública - qualquer pessoa que a efetue estará no espectro do presente estudo. No próximo item do presente capítulo iremos tratar deste critério.

Por fim, podemos tentar listar quem são os particulares executores de atividades públicas, correndo o risco de, frente a situações práticas específicas, pecar pelo esquecimento de uns e pela evocação equivocada de outros. É necessário dizer, outrossim, que ante a imprecisão de conceitos, melhor se revela indicar o elenco de particulares, para os fins desta tese. Assumimos os riscos de nossa pretensão. São eles:

i) Concessionários de serviços públicos e de obras públicas:

i.1) pessoas jurídicas de direito privado;

i.2) consórcio de pessoas jurídicas de direito privado;

i.3) sociedades de propósitos específicos.

assim mencionando a Constituição Federal estaria retirando as fundações públicas do âmbito da Administração indireta, para incluí-las numa "Administração fundacional". Parece, no entanto, melhor o entendimento que inscreve as fundações públicas no rol das entidades da Administração indireta. Isso porque o próprio Dec.-lei 200/67 assim prevê; e, por outro lado, todas as leis de reestruturação da Administração federal posteriores à Constituição de 1988 repartem-na em direta e indireta, não mencionando “Administração fundacional". Além do mais, outros dispositivos da Constituição Federal levam à convicção de que a Administração Pública se reparte somente em direta e indireta, nesta última se incluindo as fundações públicas.” (MEDAUAR, Odete. Direito administrativo moderno. 12. Ed. São Paulo: RT, 2008, pp. 67/68).

${ }^{7}$ Lei Federal no $11.107 / 2005$ :

Art. $6^{\circ} \mathrm{O}$ consórcio público adquirirá personalidade jurídica:

I - de direito público, no caso de constituir associação pública, mediante a vigência das leis de ratificação do protocolo de intenções;

(...)

$\S 1^{\circ} \mathrm{O}$ consórcio público com personalidade jurídica de direito público integra a administração indireta de todos os entes da Federação consorciados. 
ii) Permissionários de serviços públicos:

ii.1) pessoas físicas;

ii.2) pessoas jurídicas de direito privado.

iii) Autorizatários de serviços públicos.

iii.1) pessoas físicas;

iii.2) pessoas jurídicas de direito privado.

iv) Ordens e conselhos profissionais.

v) Fundações de apoio.

vi) $\quad$ Empresas semiestatais $^{89}$.

\footnotetext{
${ }^{8}$ Adotaremos como conceito de empresa semiestatal o apresentado por Carlos Ari Sundfeld, Rodrigo Pagani de Souza e Henrique Motta Pinto: "Entre as ações do movimento de reforma do estado que tomou impulso no Brasil a partir da metade dos anos 1990 destaca-se a cada vez mais frequente associação empresarial do poder público com particulares. Essa associação em geral ocorre pela participação estatal, minoritária mas relevante, em empresa cuja maioria do capital votante fica nas mãos de particulares. O controle é exercido em conjunto, mas com predominância do acionista privado. As empresas fruto dessa associação não são empresas estatais - pois o conceito de empresa estatal está vinculado à existência de maioria do estado no capital votante - de modo que elas não fazem parte da Administração Pública indireta. Mas essas empresas são parte muito relevante da estratégia de atuação do estado na economia. São empresas semiestatais." (SUNDFELD, Carlos Ari; SOUZA, Rodrigo Pagani de; PINTO, Henrique Motta. Empresas semiestatais. Revista de direito público da economia - RDPE. Belo Horizonte, ano 9, n. 36, out./dez. 2011).

9 Alexandre Santos de Aragão, ao analisar tal fenômeno, optou por denominar as empresas resultantes dessa participação acionária estatal de empresas público-privadas. Todavia, traz um elemento diferenciador do conceito apresentado na nota anterior: "Ademais, importante questão que os casos concretos podem trazer é se a participação minoritária que contemple acordo de acionistas ou golden shares, chega a transformar o Estado em controlador ou cocontrolador da sociedade, com o que seria defensável que ela teria se tornado uma empresa controlada pelo Estado, integrando-a ao regime da Administração Indireta, aplicando-se-lhes as normas de direito público cabíveis do art. 37, CF”. (ARAGÃO, Alexandre Santos de. Curso de direito administrativo. Rio de Janeiro: Forense, 2012, p. 137).
} 
vii) Serviços sociais autônomos.

viii) Entes do Terceiro Setor:

viii.1) organizações sociais;

vii.2) organizações da sociedade civil de interesse público.

ix) Particulares em colaboração com o Poder Público:

ix.1) notários e registradores;

ix.2) leiloeiros, tradutores e intérpretes públicos.

\subsection{O QUE É ATIVIDADE PÚBLICA}

Cabe ao Estado a realização de imensa gama de atividades. Apesar de heterogêneas, é possível agrupá-las por categorias, conforme pondera Celso Antônio Bandeira de Mello $^{10}$. Para o citado publicista a atividade administrativa pode ser dividida nas seguintes espécies: serviços públicos, intervenção do Estado no domínio econômico e social, limitações administrativas à liberdade e à propriedade, imposição das sanções previstas para as infrações administrativas, sacrifícios de direito e gestão dos bens públicos.

Dentre elas, ganha relevo os serviços públicos, pois nesta espécie concentrase grande parte das atividades que poderão ser delegadas à execução por particulares. Nas lições de Marçal Justen Filho ${ }^{11}$ :

${ }^{10}$ MELLO, Celso Antônio Bandeira de. Curso de direito administrativo. 21. Ed. São Paulo: Malheiros, 2006, p. 637.

${ }^{11}$ JUSTEN FILHO, Marçal. Curso de direito administrativo. 8. Ed. Belo Horizonte: Fórum, 2012, p. 687. 
Serviço público é uma atividade pública administrativa de satisfação concreta de necessidades individuais ou transindividuais, materiais ou imateriais, vinculadas diretamente a um direito fundamental, insuscetíveis de satisfação adequada mediante os mecanismos da livre iniciativa privada, destinada a pessoas indeterminadas, qualificada legislativamente e executada sob regime de direito público.

É intensa na doutrina a discussão acerca do conceito de serviço público. O acima transcrito permite diferenciar a atividade prestacional de outras exercidas pelo Estado, como a intervenção no domínio econômico e social, na qual a Administração opera em segmentos ordinariamente reservados à livre iniciativa, se atendidos alguns requisitos ${ }^{12}$, e atua como agente de mercado, sem gozar de nenhum privilégio que a diferencie das empresas privadas. A autossuficiência do mercado deixou de ser uma verdade tomada como absoluta, dando ao Estado condições de, verificadas falhas, intervir. Vale ressaltar também a possibilidade de interferência no domínio social por meio dos serviços públicos sociais, que suprem carências deste campo da livre iniciativa.

Uma terceira espécie de atuação estatal pode ser denominada de poder de polícia, embora também controverso o uso deste título pela doutrina (bem como a preservação de seu conteúdo) ${ }^{13}$. Importa, todavia, é saber o que se caracteriza como tal nesta espécie de atividade. Parece-nos mais adequado, desta forma, adotarmos o conceito dado pela própria lei - "Código Tributário Nacional, art. 78: considera-se poder de polícia atividade da administração pública que, limitando ou disciplinando direito, interesse ou

${ }^{12}$ Constituição Federal:

Art. 173. Ressalvados os casos previstos nesta Constituição, a exploração direta de atividade econômica pelo Estado só será permitida quando necessária aos imperativos da segurança nacional ou a relevante interesse coletivo, conforme definidos em lei.

13 Odete Medauar trata de apresentar a crítica e contestá-la: "No século XIX e primórdios do século XX, o poder de polícia era enfocado sob o único prisma de garantir a ordem, a tranquilidade e a salubridade públicas. Com a ampliação das funções do Estado, aumentou o campo do poder de polícia, para atuar também na ordem econômica e social, e não somente mediante restrições, mas, ainda, por imposições. Isso contribuiu para o surgimento de linha doutrinária adversa à preservação da noção de poder de polícia no direito administrativo. Uma corrente mais suave troca o título da matéria, surgindo os termos atividade administrativa de limitação, procedimentos ablatórios (Giannini), administração de vigilância; mais recentemente, atividade interventora, poder ordenador. (...) Parece que o ponto nuclear no entendimento de quem prega essa eliminação é a preocupação com um poder de polícia indeterminado, independente de fundamentação legal, baseado num suposto dever geral dos indivíduos de respeitar a ordem ou baseado num “domínio eminente" do Estado. Essa louvável preocupação perde consistência ante a realidade presente de mais solidez na concepção de Estado de direito, ante o princípio da legalidade regendo a Administração e ante a maior valoração dos direitos fundamentais." (MEDAUAR, Odete. Direito administrativo moderno. 12. Ed. São Paulo: RT, 2008, pp. 332/333). 
liberdade, regula a prática de ato ou abstenção de fato, em razão de interesse público concernente à segurança, à higiene, à ordem, aos costumes, à disciplina da produção e do mercado, ao exercício de atividades econômicas dependentes de concessão ou autorização do Poder Público, à tranquilidade pública ou ao respeito à propriedade e aos direitos individuais ou coletivos".

Decorre do poder de polícia o dever de imposição das sanções previstas para as infrações administrativas. Essa atividade reside na atuação da Administração no sentido de desmotivar o descumprimento das normas, intimidando os destinatários de suas determinações a não atentarem contra a ordem administrativa.

Os sacrifícios de direitos, por sua vez, são atuações estatais que visam a realização de interesses públicos em detrimento de direitos dos administrados. Tratando do tema Maria Sylvia Zanella Di Pietro ${ }^{14}$ assim consignou:

\begin{abstract}
Na monografia sobre Servidão Administrativa (1978:18-22), já nos havíamos colocado entre os que explicam as várias formas de intervenção do Estado na propriedade privada como manifestações do poder de polícia: "na realidade, tanto as chamadas limitações administrativas à propriedade (em sentido estrito), como a ocupação temporária, a requisição administrativa, a servidão administrativa e a desapropriação constituem formas de limitações do Estado sobre a propriedade privada, cada uma delas atingindo o exercício desse direito de maneira mais ou menos intensa, mas sempre com o objetivo de satisfazer o interesse público. Assim, em sentido amplo, as limitações administrativas abrangem todas essas modalidades; em sentido restrito, referem-se apenas àquelas impostas pelo poder de polícia do Estado, condicionando o exercício do direito de propriedade ao bem-estar social, sem implicar desdobramento dos poderes inerentes ao domínio.
\end{abstract}

Com razão a doutrinadora ora trazida à baila. Decorrem do poder de polícia os sacrifícios de direitos/limitações administrativas ${ }^{15}$ que dão ao Estado condições de comprimir direitos dos administrados. Todavia, manteremos, para fins de sistematização

\footnotetext{
${ }^{14}$ DI PIETRO, Maria Sylvia Zanella. Direito administrativo. 22. Ed. São Paulo: Atlas, 2009, p. 126.

15 Celso Antônio Bandeira de Mello aponta diferença entre sacrifícios de direitos e limitações administrativas: "Enquanto nas limitações administrativas a Administração nada mais faz que conter os administrados na intimidade da esfera de seus direitos, tal como delineados pela lei, nos sacrifícios de direito, os direitos já compostos e definidos pela lei são objeto de uma compressão ou de uma supressão por uma providência administrativa." (MELLO, Celso Antônio Bandeira de. Curso de direito administrativo. 21. Ed. São Paulo: Malheiros, 2006, p. 639).
} 
do presente estudo, como atividades estatais diversas, pois analisaremos a possibilidade de delegação de cada uma à execução por particulares.

Por fim, seguindo a sistematização proposta por Celso Antônio Bandeira de Mello para diferenciação das atividades administrativas, temos a gestão dos bens públicos, ou seja, a gerência de seu patrimônio, determinando suas destinações e aplicações aos fins que se pretendem alcançar.

Afora as atividades acima explicitadas, parece-nos assistir razão ao Professor Marçal Justen Filho ${ }^{16}$ que, ao tratar dos tipos de atividade administrativa, aponta também o fomento e a regulação econômico-social (talvez alguns consigam visualizar essas duas atividades como incursas dentre as já acima tratadas; para nós não estão compreendidas em nenhuma delas). Conforme leciona, fomento é uma atividade administrativa de intervenção no domínio econômico para incentivar condutas dos sujeitos privados mediante a outorga de benefícios diferenciados, inclusive mediante a aplicação de recursos financeiros, visando a promover o desenvolvimento econômico e social ${ }^{17}$. Tal atividade difere do serviço público - neste a Administração é a titular da atividade, executando-a diretamente ou delegando sua execução a particulares; naquele é apenas uma estimuladora de sua efetivação, cabendo à livre iniciativa sua consecução.

O fomento, enquanto atividade estatal, também não pode ser confundido com a atuação regulatória do Estado. Para Marçal Justen Filho, a regulação econômicosocial consiste na atividade estatal de intervenção indireta sobre a conduta dos sujeitos públicos e privados, de modo permanente e sistemático, para implementar as políticas de governo e a realização dos direitos fundamentais ${ }^{18}$. A diferença reside no seguinte aspecto: na regulação são dados, pelo Estado, parâmetros de liberdade de atuação privada; no fomento são dados incentivos para que os particulares, atuando dentro das balizas

\footnotetext{
${ }^{16}$ Op. Cit..

${ }^{17}$ Op. Cit., p. 677.

${ }^{18}$ Op. Cit., p. 637.
} 
traçadas pela regulação, desenvolvam atividades consideradas, naquele momento, de interesse do Estado.

Também não se deve confundir regulação com poder de polícia. Apesar de se ter regulação através do exercício do poder de polícia, não se restringe a isso. $\mathrm{Na}$ regulação, a atuação estatal visa ao atingimento de objetivos econômicos e sociais desejáveis. No poder de polícia, a finalidade está muito mais atrelada à observância do princípio da legalidade, na verificação da atuação dos particulares.

Indicadas as funções da Administração, ou seja, os âmbitos de sua competência, podemos partir do raciocínio de que toda e qualquer atividade administrativa (sejam elas quantas e quais forem) tem, em termos gerais, duas finalidades precípuas: a ordenação da sociedade e a manutenção de condições que propiciem a sua perpetuidade.

Acima está, portanto, o que será considerado "atividade pública". Adiante serão analisadas quais delas poderão ser delegadas à execução por particulares, dando ensejo à análise do modal remuneratório dos seus executores. 


\section{ATIVIDADES PÚBLICAS DELEGÁVEIS À EXECUÇÃO POR PARTICULARES}

Das atividades administrativas tratadas no capítulo anterior apenas algumas podem ser alvo de delegação/entrega à execução por particulares. Somente essas serão alvo de nossa análise, pois é a sua execução pela iniciativa privada que dará ensejo à remuneração, tema desta tese.

Uma premissa norteará a divisão que se pretende fazer entre atividades delegáveis e não delegáveis: são delegáveis todas e quaisquer atividades nas quais não seja necessário, para sua efetivação, o emprego ou avocação do poder de império do Estado. Neste sentido são as lições de Fernando Vernalha Guimarães ${ }^{19}$ :

${ }^{19}$ GUIMARÃES, Fernando Vernalha. As parcerias público-privadas e a transferência de atividades de suporte ao poder de polícia: em especial, a questão dos contratos de gestão privada de serviços em 
Referidas competências (exercício de certas funções públicas, como a manifestação do poder de polícia, da função jurisdicional, entre outras exclusivas do Estado) caracterizam-se, desde sempre, como funções típicas estatais indelegáveis à gestão privada, por traduzirem atividades que pressupõem o exercício do poder estatal destinado à realização de valores fundamentais. A orientação pressupõe o conteúdo do princípio da República, que impõe a reserva de poderes instrumentais à satisfação do interesse do povo nas mãos do Estado. Sua partilha não poderá ser admitida, ante o risco de frustração de objetivos constitucionais que deverão ser perseguidos pelo Estado. As competências instrumentais a esse fim são inalienáveis e intransferíveis. Essa concepção é admitida em inúmeros ordenamentos.

No Brasil é tradicional o reconhecimento acerca da indelegabilidade de determinadas funções estatais. As atividades essenciais de produção/aplicação do Direito, do monopólio da força e da imposição dos tributos são atingidas pela limitação, como refere a doutrina.

Vera Monteiro $^{20}$, em valoroso estudo sobre as concessões, foi feliz ao tecer o seguinte comentário:

\begin{abstract}
A proposta deste trabalho é que o gênero "concessão" não depende do conceito de serviço público e admite a delegação de atividade não-privativa do Estado. Toda atividade estatal de interesse público é potencialmente delegável (serviço público, serviço econômico, serviço social e serviço administrativo). Eventual indelegabilidade decorre de vedação expressa na Constituição ou norma local, ou com relação a eventual núcleo de autoridade existente para o exercício da atividade concedida. Neste último caso são os atos de autoridade que não poderão ser delegados a particulares.

(grifamos)
\end{abstract}

Mantendo a ordem de apresentação das atividades explicitadas no capítulo anterior, iniciaremos analisando os serviços públicos. Neste particular, parece não restar dúvidas acerca da possibilidade de sua delegação à execução privada:

Constituição Federal:

Art. 175. Incumbe ao Poder Público, na forma da lei, diretamente ou sob regime de concessão ou permissão, sempre através de licitação, a prestação de serviços públicos.

Percebe-se que a possibilidade de delegação da prestação de serviços públicos decorre do próprio texto constitucional, explicitada pela legislação ordinária, a saber:

estabelecimentos prisionais. In: SUNDFELD, Carlos Ari (Coord.). Parcerias público-privadas. São Paulo: Malheiros, 2005, pp. 386/387.

${ }^{20}$ MONTEIRO, Vera. Concessão. São Paulo: Malheiros, 2010, p. 157. 
Lei Federal no. 8.987/1995:

Art. $2^{\circ}$ Para os fins do disposto nesta Lei, considera-se:

(...)

II - Concessão de serviço público: a delegação de sua prestação, feita pelo poder concedente, mediante licitação, na modalidade de concorrência, à pessoa jurídica ou consórcio de empresas que demonstre capacidade para seu desempenho, por sua conta e risco e prazo determinado.

(sem ênfase no original)

Lei Federal $\mathrm{n}^{\circ}$. 11.079/2004:

Art. $2^{\circ}$ Parceria público-privada é o contrato administrativo de concessão, na modalidade patrocinada ou administrativa.

$\S 1^{\circ}$ Concessão patrocinada é a concessão de serviços públicos ou de obras públicas de que trata a Lei 8.987, de 13 de fevereiro de 1995, quando envolver, adicionalmente à tarifa cobrada dos usuários contraprestação pecuniária do parceiro público ao parceiro privado.

Odete Medauar $^{21}$, ao tratar da figura da concessão, leciona:

Para a compreensão do teor da Lei 8.987, de 13.2.95, a chamada "lei das concessões" e outros textos legais sobre a matéria, é relevante ter presente o conceito de concessão, seus antecedentes e evolução. Necessário se torna, ainda, compará-la às figuras da permissão e autorização de serviço.

Essas três figuras do direito administrativo dizem respeito à gestão ou execução dos serviços públicos, considerados, em essência, como aquelas atividades que atendem as necessidades fundamentais da população e que, por isso, são assumidas pelo poder público.

O poder público, a quem incumbe essas atividades (conforme prevê o art. 175 da $\mathrm{CF}$ ), poderá optar por transferir sua execução ao setor privado, atribuindo-a a pessoas físicas, pessoas jurídicas e a consórcios. Essa transferência classicamente vem se efetuando mediante as figuras da concessão, permissão e autorização de serviços.

\section{E Maria Sylvia Zanella Di Pietro ${ }^{22}$, lidando com as peculiaridades das} concessões, fez constar:

O poder concedente só transfere ao concessionário a execução do serviço, continuando titular do mesmo, o que permite dele dispor de acordo com o interesse público; essa titularidade é que lhe permite alterar as cláusulas regulamentares ou rescindir o contrato por motivo de interesse público.

${ }^{21}$ MEDAUAR, Odete. A figura da concessão. In: MEDAUAR, Odete (Coord.). Concessão de serviço público. São Paulo: RT, 1995, p. 11.

${ }^{22}$ Op. Cit., pp. 294/295. 
A delegação da execução de serviços públicos não é um fenômeno presente apenas no Brasil. Boa parte dos países do planeta lida com tal instituto. Tratando da matéria no direito italiano José Luis Palazzo, Domingo Juan Sesín e Víctor Armando Rolón Lembeye ${ }^{23}$ destacaram:

\begin{abstract}
El nuevo ordenamento legal, en su art. 22, estabelece las siguientes técnicas o formas de prestación de los servicios públicos locales: administración, concesión, ente especial, institución social y sociedade por acciones con capital mayoritario.

Las reformas más importantes se han producido en las três últimas técnicas o formas mencionadas (art. 23). La colaboración de los particulares en la prestación de los servicios públicos se realiza consecuentemente por médio de nuevos instrumentos, o bien figuras ya existentes pero con relevantes modificaciones.
\end{abstract}

Fácil notar, portanto, ser completamente legítima a delegação, a particulares, da execução de atividades tomadas como serviços públicos. Aliás, cumpre trazer à baila interpretação que nos parece ganhar maior coerência a cada dia: o constituinte, ao dar a opção à Administração Pública de prestar diretamente, ou não (conceder ou permitir), serviços públicos, acabou por forçar sua delegação. Expliquemos: a Administração deve se pautar por uma série de princípios $^{24}$, dentre eles o da eficiência. Considerando ser o particular, atualmente, visivelmente mais eficiente do que o Poder Público na execução de qualquer atividade prestacional (especialmente em razão de sua estrutura organizacional e sistemática funcional), podemos concluir: a delegação da prestação de serviços públicos deixou de ser uma opção do administrador, cuja missão é dar cumprimento aos preceitos constitucionais.

Tal raciocínio não neutraliza os poderes que o Concedente terá perante o concessionário/permissionário do serviço, inclusive o de retomar a sua execução quando

\footnotetext{
${ }^{23}$ PALAZZO, José Luis; SESÍN, Domingo Juan; LEMBEYE, Víctor Armando Rolón. La trasformación del estado - tendencias actuales - innovaciones en el derecho italiano y europeo. Buenos Aires: Ediciones Depalma, 1992, p. 166.

${ }^{24}$ Constituição Federal:

Art. 37. A administração pública direta e indireta de qualquer dos Poderes da União, dos Estados, do Distrito Federal e dos Municípios obedecerá aos princípios da legalidade, impessoalidade, moralidade, publicidade e eficiência e, também ao seguinte: 
considerar a prestação privada inadequada. Todavia, reforça a ideia de, hoje, ser o Estado muito mais um gestor do que um prestador de serviços públicos ${ }^{25}$.

A intervenção do Estado no domínio econômico e social, outra espécie de atividade administrativa, impõe uma lógica inversa à da delegação. Nessa modalidade de atuação estatal há uma exploração de atividade econômica antes titularizada pelo próprio "mercado", ou seja, aberta à livre iniciativa. Presentes os requisitos constitucionais (segurança nacional ou relevante interesse coletivo), e apenas quando a iniciativa privada se mostrar incapaz de, sozinha, suprir as necessidades públicas da atividade em jogo, pode o Estado vir a explorá-la ${ }^{26}$.

Nesse sentido, o Estado passará a ser concorrente dos particulares, com eles competindo em igualdade de condições. Existe, portanto, não a delegação, mas sim a assunção de atividades por parte da Administração.

A disputa de mercado em paridade com os agentes privados levou o Estado a dispor de artifícios que o permitissem ganhar eficiência. Assim, as empresas públicas e as sociedades de economia mista são os instrumentos dos quais o Poder Público lança mão quando busca atuar diretamente na esfera da livre iniciativa, dotando-as de personalidade de direito privado.

\footnotetext{
${ }^{25}$ Gustavo Henrique Justino de Oliveira, analisando a evolução do Direito Administrativo (destacando a passagem da era do "não contrato" ao que hoje podemos chamar de "Estado Contratual"), aponta não ser mais tarefa principal do Estado neste ainda início do século XXI a realização direta de "ações tendentes à satisfação das necessidades coletivas". Afirma que "o fim do Estado contemporâneo é o de constituir-se em canal e instrumento indispensáveis para a promoção do desenvolvimento dos indivíduos e da própria sociedade". (OLIVEIRA, Gustavo Henrique Justino de. Estado contratual, direito ao desenvolvimento e parceria público-privada. In: TALAMINI, Eduardo; JUSTEN, Mônica Spezia (Coords.). Parcerias públicoprivadas, um enfoque multidisciplinar. São Paulo: RT, 2005, p. 93).

${ }^{26}$ A atuação estatal no domínio econômico apenas nessas condições é o que compõe o denominado pela doutrina de princípio da subsidiariedade.
} 
Como bem observa Alexandre Santos de Aragão ${ }^{27}$, as empresas do Estado se caracterizam pelo hibridismo: "a adoção de um regime jurídico essencialmente privado, mas com inúmeras derrogações de direito público”. É na personalidade jurídica de direito privado que tais empresas encontram condições de enfrentar a ousadia, a criatividade e a eficiência dos particulares.

Como é sabido, empresas públicas são aquelas constituídas por capital exclusivamente público, enquanto que as sociedades de economia mista são constituídas por capital público e privado. Nesta esteira, poder-se-ia pensar, no caso das sociedades de economia mista, numa delegação de atividade por via transversa. Expliquemos: ao assumir atividade antes restrita ao setor privado, a Administração passa a intervir na livre iniciativa como um novo agente de mercado. Está, mesmo que subsidiariamente, exercendo atividade pública (intervenção do Estado no domínio econômico). Ao assim agir, o faz por ter detectado, de regra, uma insuficiência do setor privado - com ele concorrendo em igualdade de condições. Nessa atuação, a estatal se remunerará com a exploração da própria atividade comercial (vendendo produtos, prestando serviços).

Consideremos agora o particular acionista de sociedade de economia $\operatorname{mista}^{28}$. Ele investirá seu capital visando obter lucro (essa a lógica do sistema capitalista). Estará, portanto, indiretamente prestando atividade administrativa (intervindo no domínio econômico) e, por isso, estará obtendo remuneração (dividendos de sua participação acionária).

Diante deste raciocínio é possível concluir que, mesmo diante de atividade administrativa aparentemente exclusiva do Estado, é possível visualizar parcelas

\footnotetext{
${ }^{27}$ Op. Cit., p. 123.

${ }^{28}$ Decreto-Lei $\mathrm{n}^{\circ} .200$, de 25 de fevereiro de 1967:

Art. $5^{\circ}$ Para os fins desta lei, considera-se:

(...)

III - Sociedade de Economia Mista - a entidade dotada de personalidade jurídica de direito privado, criada por lei para a exploração de atividade econômica, sob a forma de sociedade anônima, cujas ações com direito a voto pertençam em sua maioria à União ou a entidade da Administração Indireta.
} 
delegáveis a particulares, não como executor direto, mas como investidor e partícipe da estatal interventora no domínio econômico.

Com relação ao poder de polícia, a discussão a respeito da possibilidade de sua delegação é permeada por diversos nuances. À primeira vista poder-se-ia dizer ser indelegável tal atividade administrativa, pois seu exercício aparentemente é reflexo do mais puro emprego do poder de império do Estado. Contudo, hoje não nos parece a maneira mais adequada de enfrentamento do tema.

Celso Antônio Bandeira de Mello $^{29}$ afirma ser corretíssimo o entendimento de que não se pode atribuir atos de polícia a particulares. Por envolverem o exercício de misteres tipicamente públicos, caso permitido fosse estar-se-ia a ofender o equilíbrio entre os mesmos, autorizando clara supremacia de uns sobre outros. Em verdade o autor admite a delegação do exercício de atos desta natureza em algumas situações (poderes reconhecidos aos capitães de navios). Contudo, conclui serem circunstâncias excepcionais.

O exercício do poder de polícia decorre da concatenação de uma infinidade de atos (e não na execução de um único). Nessa linha de raciocínio, é possível identificar alguns desses atos que são necessariamente dependentes da atuação do agente estatal para serem válidos; outros tantos, todavia, podem ser praticados por particulares.

Em estudo específico sobre os limites à delegação do poder de polícia tivemos a oportunidade de consignar ${ }^{30}$ :

Podemos dizer, portanto, que o exercício do poder de polícia se dá através da somatória destes elementos, assim entendidos: i) legislação: é a norma de polícia, regra que estabelece os limites do exercício dos direitos individuais - indicando, mesmo que implicitamente, qual ou quais direitos fundamentais individuais serão prejudicados em prol do interesse público maior

\footnotetext{
${ }^{29}$ Op. Cit., p. 797.

30 MIGUEL, Luiz Felipe Hadlich. Limites à delegação do poder de polícia. In: MEDAUAR, Odete; SCHIRATO, Vitor Rhein (Coords.). Belo Horizonte: Fórum, 2013. (No prelo)
} 
a ser resguardado pela atuação da Administração; ii) consentimento: é a permissão que o Poder Público dá ao exercício de direito que dependa da autorização do Estado; iii) fiscalização: constatação de cumprimento das regras e condições estabelecidas pelo consentimento; e $i v$ ) sanção: aplicação de penalidades aos que não obedeceram as regras e condições estabelecidas pelo consentimento. Nada mais é do que uma medida punitiva - a forçar o cumprimento do estabelecido.

(...)

Dos 4 (quatro) elementos que consideramos compor os atos de polícia, temos por indelegável apenas a legislação (podendo advir da própria constituição, da lei ou de regulamento), pois carece de legitimidade democrática, dando conformidade à atuação administrativa.

Boa parte dos atos que compõem o exercício do poder de polícia são delegáveis. Mesmo a imposição das sanções previstas para as infrações administrativas (parcela mais autoritária de sua construção), apesar de não ser comum, por vezes é delegável (vide Bloco C - "execução de atos de polícia", capítulo 13). Nesta esteira, executando o particular atividade administrativa, deverá ser remunerado.

Já os sacrifícios de direitos são atuações típicas da Administração. Não obstante decorrerem do poder de polícia, com ele não se confundem e, portanto, são indelegáveis, pois, para que efetivamente se caracterizem, dependem de atos de autoridade, inviabilizando sua execução privada.

A gestão dos bens públicos, por sua vez, merece uma maior explicitação. Os bens públicos são aqueles bens, imóveis e móveis, que em conjunto formam o domínio público. A gestão desse patrimônio cabe ao seu proprietário, sendo indelegável tal atribuição. Isso porque é inerente à qualidade de dono o poder de dispor de seus bens. Outrossim, delegar sua gestão, em última análise, seria o mesmo que entregar ao particular o poder de alterar a afetação desses bens (imóveis), algo dependente de lei ou de ato do Executivo.

Tem se difundido na Administração Pública, outrossim, a contratação do serviço de gerenciamento de frota. Nesse contrato o Poder Público entrega ao particular toda a gestão de parte de seus bens, ficando a cargo do agente privado o controle de uso, o abastecimento e a manutenção de seus veículos. Tal contrato, apesar de permitir a 
administração privada de parcela do patrimônio público, nada mais é do que um contrato de prestação de serviços. Quem decide se irá ou não usufruir do bem, como dele irá se utilizar e em que horário e local, são os servidores da Administração. Não há delegação de atividade pública, pois a atividade de gestão do patrimônio continua nas mãos do Estado (é o Estado quem compra e vende os veículos, determina quem poderá utilizá-los e qual sua finalidade). O particular apenas otimiza sua administração, sendo remunerado por isso.

Por fim, o fomento e a regulação econômico-social também não integram o grupo de atividades administrativas que, teoricamente, poderiam ser delegadas à execução por particulares. No fomento, a Administração oferece incentivos. Só se pode oferecer o que se detém. No caso, os incentivos oferecidos são detidos pelo Estado, cabendo somente a ele esse desiderato. Na regulação, por sua vez, há a intervenção estatal no sentido de direcionar a conduta dos sujeitos. Para tanto, imperiosa a existência de legitimidade na criação desses comandos balizadores, sob pena de quebra da lógica do Estado de Direito. O particular não a detém, nem poderia recebê-la por delegação de seu titular, pois a legitimidade democrática é indelegável e, portanto, indelegável a atividade regulatória ${ }^{31}$.

\footnotetext{
31 Talvez alguns considerem delegável a função de regulação, especialmente quando se deparam com determinações da bolsa de valores, do Operador Nacional do Sistema Elétrico - ONS, dentre outras associações que coercitivamente impõem suas regras. A nosso ver não passam de comandos operacionais, mais ligados à gestão da atividade tutelada pela entidade do que à sua regulação. Não se trata, portanto, de regulação pura, pois carecem de generalidade e abstração. Alexandre Santos de Aragão denomina tal fenômeno de "regulação pública não estatal ou autorregulação regulada", admitindo-a desde que sujeita a algum controle do Estado. (ARAGÃO, Alexandre Santos de. Curso de direito administrativo. Rio de Janeiro: Forense: 2012, pp. 204/205). Vale também trazer à lume os casos do Conselho Administrativo de Defesa Econômica - CADE e da Comissão de Valores Mobiliários - CVM. Em ambos, apesar de não objetivarem a regulação dos respectivos setores de atuação, a prática tem demonstrado que usualmente assim têm agido. Tais entidades, a nosso ver, têm natureza de agências e, portanto, podem exercer tal função.
} 
3. A

EXPLORAÇÃO

ECONÔMICA

DE

ATIVIDADES TOMADAS

\section{COMO ESSENCIAIS}

3.1. Conflito natural de interesses; 3.2 . Objetivo do delegatário de atividade pública - lógica econômica.

\subsection{CONFLITO NATURAL DE INTERESSES}

As relações entre Estado e iniciativa privada eram encaradas, tempos atrás, como pactos entre adversários. Cada parte buscava a obtenção de seus próprios interesses, não se importando com a satisfação do interesse comum envolvido na negociação. 
Nas delegações de atividades públicas à execução por particulares esse conflito era ainda mais nítido. O Poder Público buscava a exploração do agente privado, com vistas à obtenção do máximo de qualidade na atividade a ele concedida. Já o particular procurava prestar o serviço a seu cargo com o menor ônus, no limite do mínimo aceitável pela Administração, visando o maior lucro.

Esse conflito de interesses é natural em qualquer relação contratual e continua a existir. Contudo, com o passar do tempo e a evolução do relacionamento público/privado notou-se que a perfeita gestão desse conflito culmina num exponencial ganho ao interesse público, razão de existir da própria Administração. Nos contratos administrativos um fator externo à contratação (alheio aos interesses diretos das partes envolvidas) se sobressai como objetivo principal do pacto: o interesse público passa a nortear a relação entabulada. É ele que leva a Administração a conceder dada atividade, ao atribuir à eficiência da iniciativa privada a possibilidade de otimização de custos e oferecimento de serviços de melhor qualidade aos administrados.

Ademais, percebeu a Administração que achacar o particular acabaria por prejudicar a atividade a ele concedida. Notou o agente privado, de outra feita, que explorar no limite a atividade pública, perdendo de vista o equilíbrio do negócio como um todo, acabaria por fulminar a relação entabulada. Houve então uma modificação dos paradigmas, existindo hoje um cenário muito mais adequado ao estabelecimento de relações entre o público e o privado. O consenso tomou o lugar da "supremacia". A imperatividade deu lugar ao diálogo.

Em trabalho específico sobre as relações entre o público e o privado tivemos a oportunidade de observar ${ }^{32}$ :

\footnotetext{
${ }^{32}$ MIGUEL, Luiz Felipe Hadlich. As relações entre o público e o privado nas parcerias público-privadas. In: MEDAUAR, Odete; SCHIRATO, Vitor Rhein (Coords.). Belo Horizonte: Fórum, 2014. (Inédito)
} 
(...) a clara oposição de objetivos perseguidos por cada um dos atores perde força quando cotejado com o objetivo maior do relacionamento por eles entabulado. O Poder Público busca, no particular, maior eficiência na prestação de dada atividade; de outro lado, o particular se aproveita de potencial econômico deveras elevado existente nas atividades titularizadas pelo Poder Público. A junção dessa troca de propósitos leva a um resultado que agrada a todos os envolvidos na relação.

Em suma: como em qualquer relação, existem alguns aspectos conflitantes. Cada parte detém um interesse diverso. Existe, porém, um núcleo de interesses comuns, capazes de suplantar em importância as diversidades e manter equilibrado o relacionamento. Nos tratos entre público e privado a lógica é exatamente esta. Ambos procuram obter algo um do outro, contudo pautados pelo atingimento de um objetivo comum. Hoje mais importante do que a satisfação individual dos interesses envolvidos, estão os aspectos comuns que a ela dão sustentação.

\subsection{OBJETIVO DO DELEGATÁRIO DE ATIVIDADE PÚBLICA - LÓGICA ECONÔMICA}

Por óbvio que o particular, na maior parte das vezes, busca o lucro ao se lançar como agente executor de atividade administrativa. Esta expectativa, ademais, deve alcançar patamares superiores a de investimentos tradicionais (especialmente bancários), pois, caso contrário, os recursos privados buscariam outros destinos.

$\mathrm{Na}$ lógica das delegações de atividades deve-se ter em mente, portanto, que as fontes de remuneração disponíveis pelo agente privado devem propiciar ganhos capazes de suportar os custos de investimento na infraestrutura ou aquisição de bens necessários à perfeita consecução de seus objetivos, os custos operacionais e a parcela de lucratividade estabelecida pela proposta ensejadora de seu chamamento. 
Se pode afirmar, sem receio de cometer qualquer equívoco, que o anseio do agente privado no auferimento de lucro na exploração empresarial de atividades voltadas a necessidades essenciais é legítimo. Neste sentido são as lições de Rafael Wallbach Schwind $^{33}$ :

A verdade é que a remuneração adequada, que envolve os custos do serviço e o retorno do concessionário, é essencial para o êxito de qualquer concessão. Eventual remuneração insuficiente inviabilizaria a prestação do serviço e, por conseguinte, impediria a consecução dos objetivos buscados pela Administração.

Na mesma linha caminham as considerações de Celso Antônio Bandeira de Mello $^{34}$, ao analisar especificamente as parcerias público-privadas:

Os particulares querem o quê? O que é legítimo: ganhar dinheiro. Só e só. Ou alguém acha que os particulares, quando entram numa relação - vamos chamar de contrato, de parceria, de concessão, o nome que queiram -, o que eles querem? Ah! Vamos deixar esse povo feliz! Não! Eles querem ganhar o dinheiro deles, e é legítimo. O que o Estado quer? O que o Estado quer? O Estado quer - mesmo que ele não cumpra - que o cidadão fique maximamente satisfeito com a qualidade da prestação de serviço.

A expectativa de lucro é o que atrai o capital. Não haveria particulares (salvo algumas exceções, como adiante restará demonstrado) interessados em prestar serviços públicos, por exemplo, não fosse a possibilidade de exploração empresarial desse nicho comercial. A natureza da atividade, que a princípio coloca em diálogo interesses antagônicos, acaba por permitir sua convivência harmônica. O equilíbrio dessa balança encontra respaldo na remuneração adequada, como adiante veremos.

${ }^{33}$ Op. Cit., p. 39.

${ }^{34}$ MELLO, Celso Antônio Bandeira de. As parcerias público-privadas e a observância dos princípios constitucionais. Revista do Tribunal de Contas do Estado de Minas Gerais, Belo Horizonte, TCEMG, v. 56, n. 3, jul./set. 2005, p. 218. 


\section{ATIVIDADE: SERVIÇO PÚBLICO}

4.1. Regime remuneratório do prestador de serviço público; 4.2. Sistema usual; 4.3. A questão da equação econômico-financeira da avença; 4.4. Custos supervenientes.

Das atividades da Administração passíveis de execução por particulares os serviços públicos são os de maior relevância. É nos serviços públicos que o cidadão encontra condições de viver em sociedade; eis a razão de nesta seara residir grande parte das atuações administrativas.

O direito administrativo vem passando por uma grande transformação, intensificada nos últimos tempos pelo surgimento de contextos sociais dinâmicos, como exposto na introdução deste trabalho. Neste já longo caminho evolutivo o direito administrativo, em determinado momento, foi concebido a partir da ideia de serviço público. A denominada Escola do Serviço Público (também chamada de Escola de 
Bordeaux, como bem observa Odete Medauar ${ }^{35}$ ) tomava como base do direito administrativo o serviço público, sendo o Estado seu grande prestador.

Passou também por mudanças a concepção do que é serviço público. Naquela época apenas o Estado poderia prestá-los. Hoje, tomássemos tal conceito como verdadeiro e o presente trabalho não teria a menor condição de existir. Sem dúvida poderíamos adotar a expressão serviço público num sentido amplo, englobando toda e qualquer atuação da Administração ${ }^{36}$. Contudo, para o presente ensaio nos interessa sentido mais restrito, adequadamente exposto no conceito elaborado por Alexandre Santos de Aragão $^{37}$ :

Serviços públicos são as atividades de prestação de utilidades econômicas a indivíduos determinados, colocadas pela Constituição ou pela lei a cargo do Estado, com ou sem reserva de titularidade, e por ele desempenhadas diretamente ou por seus delegatários, gratuita ou remuneradamente, com vistas ao bem-estar da coletividade. ${ }^{38}$

Agregaríamos ao conceito acima apenas a noção de essencialidade que, apesar de não estar presente em todas as atividades atualmente rotuladas como serviços públicos, é perceptível em boa parte delas.

$\mathrm{Na}$ realidade, é o momento sociocultural de um povo que define se uma atividade prestacional será taxada de serviço público ou não. A partir de dado momento recebe, da constituição ou da lei, tal natureza, e passa a sofrer os influxos de todo um

\footnotetext{
${ }^{35}$ Op. Cit., p. 314.

${ }^{36}$ Odete Medauar apresenta didática explicação acerca da questão: “A expressão serviço público às vezes vem empregada em sentido muito amplo, para abranger toda e qualquer atividade realizada pela Administração pública, desde uma carimbada num requerimento até o transporte coletivo. Quando se fala "ingresso no serviço público", é atribuído sentido amplo ao termo. Se esta fosse a acepção adequada, todo o direito administrativo conteria um único capítulo, denominado "serviço público", pois todas as atividades da Administração aí se incluiriam. No sentido amplo da expressão "serviço público" são englobadas também as atividades do Poder Judiciário e do Poder Legislativo, quando se menciona o seguinte: O Judiciário presta serviço público relevante; o Legislativo realiza serviço público. Evidente que aí a expressão não se reveste de sentido técnico, nem tais atividades sujeitam-se aos preceitos norteadores da atividade tecnicamente caracterizada como serviço público". (MEDAUAR, Odete. Direito administrativo moderno. 12. Ed. São Paulo: RT, 2008, p. 313).

${ }^{37}$ Op. Cit., pp. $367 / 368$.

${ }^{38}$ Em sua valorosa obra o autor destrincha cada elemento de seu conceito.
} 
sistema de normas e princípios. A doutrina não é uníssona no concernente aos princípios diretores dessa atividade. Para nós o da continuidade ${ }^{39}$, da atualidade $^{40}$ e da paridade de tratamento $^{41}$ são os que efetivamente diferenciam a atividade tomada como serviço público de outra qualquer (mesmo que prestada pela própria Administração).

Tratando especificamente dos serviços públicos prestados por particular, este capítulo visa apresentar especificidades do regime remuneratório, partindo do sistema usual de remuneração, em busca da garantia constitucional de preservação da equação econômico-financeira da avença.

\subsection{REGIME REMUNERATÓRIO DO PRESTADOR DE SERVIÇO PÚBLICO}

O particular prestador de serviços públicos é, em regra, um agente em busca de oportunidades. Contudo, ao optar por executar atividade da Administração, deixa de atuar no campo de ampla liberdade, típica da livre iniciativa, subjugando-se às regras e princípios próprios do serviço público.

Todavia, não obstante atuar nos padrões e limites estabelecidos pelo Estado, não perde sua natureza de agente privado. No intuito de prestar, a contento, a atividade a

\footnotetext{
${ }^{39}$ Do princípio da continuidade extrai-se a obrigação de prestação ininterrupta da atividade por ele alcançada. Atinge os serviços prestados pela própria Administração, como também aqueles que foram delegados à prestação por particular. Neste sentido, vem à tona a discussão acerca do direito de greve dos servidores públicos. Por não existir lei específica (lembremos que a Constituição garante tal direito, nos termos da lei específica), parece-nos hoje pacífico o entendimento de que é aplicável a lei de greve da iniciativa privada (Lei $n^{\circ}$. 7.783/89). Assim, é garantido o direito de greve (tanto ao empregado de uma concessionária de serviço público, por exemplo, quanto ao servidor público), desde que mantido, num patamar minimamente razoável de funcionamento, o serviço prejudicado pela mesma.

${ }^{40} \mathrm{O}$ princípio da atualidade impõe o dever do prestador de serviço público de executá-lo utilizando-se das técnicas e equipamentos mais modernos disponíveis no mercado, adequando a atividade aos avanços tecnológicos, mantendo o serviço dentro de padrões de qualidade condizentes com a realidade do momento.

${ }^{41}$ Também conhecido como princípio da igualdade dos usuários perante o serviço público, visa garantir seu acesso indiscriminado. Cumpre ressaltar que não se está a vedar, com esse raciocínio, a diferenciação de grupos que terão acesso a determinadas "regalias". O que se deve tomar como diretriz, na aplicação concreta do princípio, é a vedação de distinções de usuários pertencentes à mesma categoria.
} 
ele delegada necessita que seus custos sejam suportados por alguma fonte de custeio. Adiante iremos analisar as diversas formas pelas quais este agente poderá ser remunerado. O importante agora é traçar algumas balizas delineadoras do que chamaremos de sistema remuneratório do prestador de serviço público.

Nesta linha, o primeiro aspecto por nós considerado essencial: não há atividade pública a ser prestada por particular sem que este detenha alguma forma de remuneração. Não poderá o Estado delegar um serviço sem a garantia, ao seu prestador, de uma fonte de custeio, sob pena de se colocar em risco a continuidade e a atualidade da atividade. Mesmo o particular assim querendo, não deve o Estado permitir a prestação de serviço público por quem não possua nenhum modal remuneratório. Com efeito, não se está a defender a inexistência de serviço público gratuito. A gratuidade (que adiante será analisada) é possível para o usuário do serviço. O particular, todavia, não poderá prestá-lo às suas expensas, sem a existência de, ao menos, potencial fonte remuneratória (ainda que oriunda de sua própria estrutura).

Decorre do raciocínio acima que a remuneração, além de necessária, deve suportar ao menos o custo da operação. Não significa que o seu prestador deverá sempre auferir lucro com a atividade. Entretanto, não poderá custeá-la, sem antes comprovar a solidez da fonte de seus recursos, sob pena de, mais uma vez, colocar em risco a continuidade e a atualidade. Neste sentido são as lições de Adilson Abreu Dallari ${ }^{42}$ :

\footnotetext{
Além disso, é importante considerar que a proposta, para ser séria, deve ser perfeitamente exeqüível, pois ninguém pode pretender manter uma proposta cujo cumprimento seja impossível, nem deve a Administração aceitar proposta cujo cumprimento seja fortemente improvável, uma vez que o interesse público não pode servir nem ao aventureirismo nem a experiências de resultados duvidosos.

(grifamos)
}

Do acima exposto é possível extrair um conjunto de ideias que, reunidas, culminam com o que denominamos de sistema remuneratório do prestador de serviço

\footnotetext{
${ }^{42}$ DALLARI, Adilson Abreu. Aspectos jurídicos da licitação. 7. Ed. São Paulo: Saraiva, 2007, p. 152.
} 
público: conjunto de elementos econômico-financeiros da delegação da execução de atividade pública a particular que envolve toda e qualquer forma de obtenção de recursos, oriundos ou não do próprio serviço colocado à disposição, devendo tais recursos se equipararem ou superarem as despesas de capital $^{43}$ e os custos operacionais ${ }^{44}$, visando a preservação da continuidade e da atualidade do serviço prestado.

\subsection{SISTEMA USUAL}

A forma tradicional de remuneração do particular prestador de serviços públicos é a cobrança de tarifa dos usuários. O usuário da atividade colocada à disposição paga por ela. Esse sistema é o mais comum, pois permite que se extraia do próprio serviço seu custeio.

As tarifas estão presentes no cotidiano das pessoas. Ao acordar e acender a luz paga-se tarifa pelo fornecimento de energia elétrica (produção, transmissão e distribuição); ao escovar os dentes, tarifa pelo fornecimento de água (captação, tratamento, distribuição, despejo das águas servidas nas redes coletoras e tratamento do esgoto); ao telefonar para a namorada, tarifa pela ligação telefônica (implementação da rede e disponibilização do sinal telefônico, fixo ou móvel); ao se deslocar ao trabalho, tarifa pela utilização do ônibus (transporte público); ao chegar em casa após um longo dia de trabalho, tarifa pelo gás utilizado na elaboração do jantar (gás encanado). Enfim, a tarifa é a forma mais usual de remuneração do particular prestador de serviço público. Neste sentido são as lições de Nidia Karina Cicero ${ }^{45}$ :

\footnotetext{
${ }^{43}$ Também conhecido no mundo corporativo por CAPEX - Capital Expenditure - é o montante de recursos despendido na construção e aquisição dos bens necessários à prestação da atividade fim da empresa.

${ }^{44}$ Também conhecido no mundo corporativo por OPEX - Operational Expenditure - são os preços contínuos atrelados à prestação da atividade gerida pela empresa. Envolve, em linhas gerais, insumos, mão de obra e despesas operacionais (alugueis, modernização dos bens físicos, manutenção, etc).

${ }^{45}$ CICERO, Nidia Karina. Servicios publicos - control y proteccion. Buenos Aires: Ediciones Ciudad Argentina, 1996, p. 45.
} 
El concesionario actúa por su cuenta y riesgo, adquiere el derecho a explorar el servicio y recibe como contraprestación una retribución, que si bien puede consistir em subsidios outorgados por el Estado concedente, en la mayoría de los casos es abonada directamente por los usuarios bajo la forma de "tarifas".

(sem ênfase no original)

Todavia, tem ganhado espaço no cotidiano da Administração novos modais remuneratórios, impulsionados especialmente pela prática das concessões e permissões e, mais recentemente, pelo advento das parcerias público-privadas. Isso porque antes as tarifas só permitiam fossem delegadas atividades cujos custos e margem de lucro pretendidos fossem facilmente suportáveis com as receitas advindas da cobrança das mesmas. Hoje, um novo universo remuneratório se apresenta como juridicamente viável, permitindo ao poder concedente oferecer contrapartidas ao prestador de serviço público, tornando economicamente possível uma imensa gama de serviços antes insustentáveis.

Ousamos afirmar que a tarifa perderá, com o tempo, sua importância na sistemática remuneratória. Abrirá espaço para modelos de concessão onde o retorno financeiro esperado advirá da exploração de potencialidades atreladas ao serviço, mas não propriamente dele.

A ousadia e a criatividade dos idealizadores de projetos encontram hoje um fértil campo de possibilidades. Cabe à legislação abrir espaço para que eventuais novos e engenhosos mecanismos remuneratórios nela encontrem guarida.

\subsection{A QUESTÃO DA EQUAÇÃO ECONÔMICO-FINANCEIRA DA AVENÇA}

Toda relação entabulada entre público e privado, desde que erigida sob uma lógica econômica, é regida por uma proporcionalidade entre encargos e receitas, visando a sua perpetuidade. Essa proporção é fixada no momento da consecução da relação. Se iniciada por processo licitatório (mais comum), a equação é traduzida pela proposta. 
É nesse momento inicial que a correlação entre os bônus e os ônus do particular se apresenta. Daí em diante qualquer alteração do pactuado deverá sempre considerar, para fins de manutenção da relação, o pressuposto equilíbrio ${ }^{46}$ do avençado.

Todo novo ônus assumido pelo particular deverá ser compensado por um

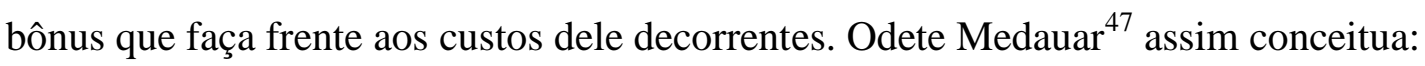

O equilíbrio econômico-financeiro significa a proporção entre os encargos do contratado e a sua remuneração, proporção esta fixada no momento da celebração do contrato. Diz respeito às chamadas cláusulas contratuais, terminologia redundante, classicamente usada para designar as cláusulas referentes sobretudo à remuneração do contratado. Além dessas, o contrato administrativo é dotado das chamadas cláusulas regulamentares, atinentes às regras de execução. O direito ao equilíbrio econômico-financeiro assegura ao particular contratado a manutenção daquela proporção durante a vigência do contrato. Se houver aumento dos encargos, a remuneração deverá ser aumentada também.

Essa garantia ao equilíbrio econômico-financeiro decorre do próprio texto constitucional:

Constituição Federal:

Art. 37. A administração pública direta e indireta de qualquer dos Poderes da União, dos Estados, do Distrito Federal e dos Municípios obedecerá aos princípios de legalidade, impessoalidade, moralidade, publicidade e eficiência e, também, ao seguinte:

(..)

XXI - ressalvados os casos especificados na legislação, as obras, serviços, compras e alienações serão contratados mediante processo de licitação pública que assegure igualdade de condições a todos os concorrentes, com cláusulas que estabeleçam obrigações de pagamento, mantidas as condições efetivas da proposta, nos termos da lei, o qual somente permitirá as exigências de qualificação técnica e econômica indispensáveis à garantia do cumprimento das obrigações.

(grifamos)

A Constituição remete à lei os termos de garantia do equilíbrio. Neste sentido, apenas para ilustrar: Lei no. 8.666/1993, art. 65, inciso I, alínea “d” e $\S 6^{\circ}$; Lei no.

${ }^{46}$ Dizemos que o equilíbrio é pressuposto pois não parece lógico o particular pactuar com a Administração caso não lhe seja, em qualquer aspecto, vantajoso.

${ }^{47}$ Op. Cit., p. 213. 
8.987/1995, art. $9^{\circ}, \S \S 2^{\circ}$ e $4^{\circ}$ e art. 11, Parágrafo único. Na lei de parcerias públicoprivadas (Lei $\mathrm{n}^{\mathrm{o}}$. 11.079/2004), apesar de não constar expressamente a garantia ao equilíbrio, alguns dispositivos remetem a esta conclusão: o inciso VII do art. $4^{\circ}$ prevê a sustentabilidade financeira e vantagens socioeconômicas dos projetos de parcerias. Já o inciso IV do art. $5^{\circ}$ determina ser obrigatória no contrato cláusula atinente às formas de remuneração e de atualização dos valores contratuais (dando a entender que a implementação dos reajustes manterá o equilíbrio da relação).

Portanto, permeará a discussão do presente estudo a questão do equilíbrio econômico-financeiro dessas relações tendentes à consecução de atividades públicas por particulares. O sistema remuneratório de qualquer delegação de serviço tangencia a equação inicial do avençado. A possibilidade de manutenção dessa equação é uma premissa que dever ser considerada antes de se formular qualquer parceria entre Estado e iniciativa privada.

\subsection{CUSTOS SUPERVENIENTES}

Por vezes as relações entre público e privado, especificamente quando executores de atividades públicas, perduram por muito tempo. A Lei de parcerias públicoprivadas, por exemplo, permite concessões com até 35 anos de duração. Tivemos contato, certa feita, em nossa rotina profissional na advocacia, com concessão de 40 anos que, por fatores alheios à vontade do agente privado, apresentava forte desequilíbrio econômicofinanceiro. Como forma de reparar os prejuízos e permitir ao particular a amortização do montante investido (nos moldes da equação inaugural), prorrogou-se por mais 40 anos o contrato.

O exemplo acima serve para demonstrar como a longevidade desse relacionamento é capaz de modificar, por completo, as condições iniciais de execução da 
atividade. Um serviço pode ser prestado com a utilização de uma tecnologia que, em pouco tempo, estará superada. Vejamos o contexto atual da telefonia móvel. Hoje a transmissão de dados supera em volume e importância a comunicação por voz. Os contratos precisam permitir a agilidade necessária à manutenção da atualidade do serviço. Custos supervenientes, especialmente na implementação de novas formas de execução da atividade pretendida, decorrem da evolução natural da atividade objeto da delegação.

Nessa esteira, é comum que custos supervenientes, ou seja, novos investimentos em infraestrutura e majoração dos valores operacionais surjam no curso da prestação do serviço. Seria inadequado não permitir ao particular a incorporação de novas técnicas e tecnologias na sua operação, pois se estaria ferindo o princípio da atualidade. Certamente, nos moldes do delineado no subitem anterior, o equilíbrio econômicofinanceiro deverá ser mantido. Todavia, não se pode imaginar atividade imutável com o transcurso do tempo, cimentando o serviço numa realidade pretérita. 


\section{A TARIFA}

5.1. Tarifa X taxa; 5.2. Natureza jurídica; 5.3. Tarifa e lucro; 5.4. Sistema de fixação das tarifas: 5.4.1. Princípio da modicidade tarifária; 5.4.2. A complexa questão da universalidade do serviço; 5.5. Revisão e reajuste.

Como já ressaltado em momento anterior, a tarifa é a forma mais comum de remuneração do particular executor de atividade pública. Pela importância e quantidade de nuances trataremos num capítulo próprio.

\subsection{TARIFA X TAXA}

Antes de tratarmos das particularidades que permeiam as tarifas é preciso apartá-las das taxas. Além de derivarem de ramos distintos da ciência jurídica (as tarifas 
advêm do direito administrativo, as taxas do direito tributário), outros aspectos as diferenciam $^{48}$. Vejamos o disposto no art. 145 da Constituição Federal ${ }^{49}$ :

\author{
Constituição Federal: \\ Art. 145. A União, os Estados, o Distrito Federal e os Municípios poderão instituir os seguintes \\ tributos: \\ (..) \\ II - taxas, em razão do exercício do poder de polícia ou pela utilização, efetiva ou potencial, de \\ serviços públicos específicos e divisíveis, prestados ao contribuinte ou postos a sua disposição;
}

Da simples leitura do dispositivo constitucional acima transcrito duas conclusões são facilmente extraíveis: $i$ ) taxa é espécie de tributo; ii) só são devidas como contraprestação pelo exercício do poder de polícia ou prestação de serviço público. Qualquer outro fato gerador afora os acima citados e que de azo à sua cobrança a inquina de inconstitucionalidade.

Outro raciocínio decorrente da intelecção do texto constitucional é o de que a uma taxa deve sempre corresponder uma atuação estatal direta ao contribuinte. Inconcebível uma taxa cujo fato gerador se relacione com uma atuação estatal genérica ou perante um terceiro (não o próprio destinatário da ação). Neste sentido é a doutrina de Paulo de Barros Carvalho ${ }^{50}$ :

\begin{abstract}
Taxas são tributos que se caracterizam por apresentarem, na hipótese da norma, a descrição de um fato revelador de uma atividade estatal, direta e especificamente dirigida ao contribuinte. Nisso diferem dos impostos, e a análise de suas bases de cálculo deverá exibir, forçosamente, a medida da intensidade da participação do Estado. Acaso o legislador mencione a existência de taxa, mas eleja base de cálculo mensuradora de fato estranho a qualquer atividade do Poder Público, então a espécie tributária será outra, naturalmente um imposto.
\end{abstract}

\footnotetext{
${ }^{48}$ O Supremo Tribunal Federal já consolidou entendimento acerca das diferenças entre tarifas e taxas. "Súmula 545: Preços de serviços públicos e taxas não se confundem, porque estas, diferentemente daqueles, são compulsórias e têm sua cobrança condicionada à prévia autorização orçamentária, em relação à lei que as instituiu."

${ }^{49}$ Vale também a leitura do art. 77 do Código Tributário Nacional (Lei n ${ }^{\circ}$. 5.172/1966):

Art. 77. As taxas cobradas pela União, pelos Estados, pelo Distrito Federal ou pelos Municípios, no âmbito de suas respectivas atribuições, têm como fato gerador o exercício regular do poder de polícia, ou a utilização, efetiva ou potencial, de serviço público específico e divisível, prestado ao contribuinte ou posto à sua disposição.

Parágrafo único. A taxa não pode ter base de cálculo ou fato gerador idênticos aos que correspondam a imposto nem ser calculada em função do capital das empresas.

${ }^{50}$ CARVALHO, Paulo de Barros. Curso de direito tributário. 13. Ed. São Paulo: Saraiva, 2000, pp. 38/39.
} 
A essa característica das taxas a doutrina atribui o nome de princípio da retributividade. Cumpre também observar que as taxas não podem ser utilizadas como formas de arrecadação de recursos para o Estado. Pelo contrário, são cobradas nos exatos limites dos custos incorridos por quem executou ato de polícia ou serviço público. Vejamos as lições de Roque Antonio Carrazza ${ }^{51}$ :

\begin{abstract}
Ao contrário do que acontece com os impostos, as pessoas políticas não podem criar taxas com o fito exclusivo de carrear dinheiro para os cofres públicos. Além disso, na medida em que o pagamento das taxas está vinculado à prestação de um dado serviço público ou à prática de um determinado ato de polícia, elas devem estar voltadas a seu custeio, e não de outros serviços ou atos de polícia, que não alcançam o contribuinte (ou que a ele não estão disponibilizados, no caso dos serviços públicos). Ainda dentro desta linha de raciocínio, não é dado ao Poder Público manipular abusivamente os serviços públicos ou as diligências que levam ao exercício do poder de polícia, só para incrementar receitas.
\end{abstract}

Não pode o Estado, no estabelecimento do quantum a ser cobrado por determinado serviço prestado, por exemplo, analisar as condições de quem do serviço usufruiu. Se assim o fizer estará utilizando base de cálculo própria de imposto, o que não é permitido pela Lei (vide nota de rodapé $n^{\circ}$. 49). Não busca o Estado, nesta seara, a obtenção de lucro. Já com relação às tarifas, começaremos transcrevendo o art. 175 da Constituição Federal:

Constituição Federal:

Art. 175. Incumbe ao Poder Público, na forma da lei, diretamente ou sob regime de concessão ou permissão, sempre através de licitação, a prestação de serviços públicos.

Parágrafo único. A lei disporá sobre:

(...)

III - política tarifária;

Extrai-se do comando constitucional serem as tarifas devidas por força da prestação de serviços públicos, quando executados por particular em atividades a ele delegadas. É neste sentido que caminha a doutrina mais abalizada:

${ }^{51}$ CARRAZZA, Roque Antonio. Curso de direito constitucional tributário. 19. Ed. São Paulo: Malheiros, 2004, p. 486. 
Maria Sylvia Zanella Di Pietro:

Onde existe concessão de serviço público, a remuneração paga pelo usuário é a tarifa e não a taxa. Se o concessionário fosse remunerado por meio de taxa, descaracterizada estaria a concessão, tendo pura e simplesmente contrato de prestação de serviço remunerado pelos cofres públicos.

(DI PIETRO, Maria Sylvia Zanella. Parcerias na administração pública. 6. Ed. São Paulo: Atlas, 2008, p. 386).

Cármen Lúcia Antunes Rocha:

Não é de se desconhecer a posição de eminentes tributaristas, segundo os quais não seria a remuneração do serviço público, ainda que prestado por concessionária, tarifa, realizável pelo preço público, mas taxa de serviço. Inaceitável seria, então, na visão dos ilustrados juristas adeptos dessa tese, a concepção que ainda domina doutrina e jurisprudência quanto à natureza de preço público atribuída ao quanto pago pelo usuário do serviço público, quando a prestação deste se der por concessionária.

(ROCHA, Cármen Lúcia Antunes. Estudos sobre concessão e permissão de serviço público no direito brasileiro. São Paulo: Saraiva, 1996, p. 76).

Mas quando o Estado presta diretamente serviços públicos, pode custear a atividade através da cobrança de tarifas? Alguns doutrinadores, com olhos no disposto no art. 145 da Constituição Federal, entendem que ao Estado prestador direto de serviços só é permitida a cobrança de taxas - estando vedada a cobrança da contraprestação pelo uso do serviço através do regime tarifário.

Do raciocínio acima exposto poderíamos extrair uma primeira diferença: taxas são devidas ao Poder Público, tarifas aos particulares. Entretanto, não é o que efetivamente ocorre. Poderia o Estado, ao prestar diretamente um serviço público, cobrar tarifas? A resposta nos parece ser positiva. Vejamos: não teria lógica "amarrar" o Estado a um sistema muito mais rígido e estanque, como é o da cobrança dos serviços públicos prestados via taxa, cuja criação depende de lei e cuja aplicação impõe a observância ao princípio da anterioridade, impedindo sua criação senão para o próximo exercício. Se pode o titular da atividade (Estado) delegá-lo a um terceiro, e se pode este terceiro utilizar os benefícios do regime tarifário (muito mais flexível e dinâmico), pode ele mesmo deste regime usufruir ${ }^{52}$.

\footnotetext{
${ }^{52}$ Tal posicionamento não é uníssono na doutrina. Muitos defendem que o Estado, por não objetivar o lucro, não estaria autorizado a se utilizar do regime tarifário quando diretamente prestar serviço público. É o que sustenta, entre outros, Leonardo Avelino Duarte: "Veja-se que a Constituição fala em política tarifária. Ou seja, ela expressamente prevê a existência da chamada "tarifa" - e não taxa -, naqueles casos em que existir delegação. Se a constituição quer e prevê a existência das tarifas só nos casos de delegação, quem pode querer e sustentar o contrário?
} 
Qual seria então a característica essencial a ensejar a aplicação de cada um dos regimes? Em valoroso estudo sobre as tarifas nas concessões Jacintho Arruda Câmara $^{53}$, após analisar a jurisprudência do Supremo Tribunal Federal, chega à seguinte conclusão:

\begin{abstract}
O caráter obrigatório do serviço de limpeza urbana foi considerado aspecto fundamental para descaracterizar a aplicação do regime tarifário. Por ser de fruição obrigatória, tal serviço somente poderia ser remunerado mediante taxa. Eis, de acordo com a jurisprudência do STF, o critério que diferenciaria a aplicabilidade do regime tributário (das taxas) do administrativo (das tarifas) em matéria de remuneração pela prestação de serviços públicos.
\end{abstract}

Em outras palavras: se ao usuário da atividade não lhe é dada a opção de dela usufruir ou não, ou seja, é compulsória sua aderência ao uso e às condições do serviço posto a sua disposição, o regime remuneratório será o das taxas. Já se a atividade a ele disponibilizada é de fruição facultativa, o regime poderá ser o tarifário (mesmo se a atividade for executada diretamente pelo Estado). $\mathrm{O}$ autor acima citado assim exemplifica: "se alguém [não] pagar a tarifa de ônibus, cujo serviço é autorizado pelo Poder Público, pode fazê-lo, sem sofrer qualquer sanção, e sem estar obrigado, para deslocar-se (o que não poderá [poderá] fazer por outro meio de transporte, ou, em último caso, a pé), a cometer infração administrativa. No caso da remoção de lixo, já que sua produção é necessária, não é possível ao particular sequer omitir-se, pois, ainda assim, estará infringindo norma de controle sanitário., 54

\footnotetext{
Pela mesma razão, imaginar o reverso seria aceitar ou que o Estado, ao prestar diretamente o serviço ou atividade pública, poderia, licitamente, querer ter lucro, ou que o concessionário e permissionário de serviços públicos não pudessem tê-lo, amarrados que estariam ao regime tributário." (DUARTE, Leonardo Avelino. Diferenças constitucionais entre as taxas, tarifas e preços públicos em sentido estrito - uma proposta de diferenciação. Disponível em: 〈http://www.fatonotorio.com.br/artigos/ver/21/diferencas-constitucionaisentre-as-taxas-tarifas-e-precos-publicos-em-sentido-estrito-uma-proposta-de-diferenciacao>. Acesso em 19 março 2013).

${ }^{53}$ CÂMARA, Jacintho Arruda. Tarifa nas concessões. São Paulo: Malheiros, 2009, p. 39.

${ }^{54}$ Op. Cit., p. 39.
} 
Mas o entendimento acima explicitado encontra opositores de peso. Rafael Wallbach Schwind ${ }^{55}$, tratando da remuneração do concessionário nas concessões comuns e nas parcerias público-privadas, assim consignou:

\begin{abstract}
Os argumentos que orientam a tese segundo a qual os serviços de fruição obrigatória só podem ser remunerados por meio da cobrança de taxas podem ser reconduzidos a dois fundamentos. O primeiro deles é o de que haveria um ato de império subordinando a conduta do usuário, o que não poderia ser feito pelo delegatário do serviço. Esse ato de império somente seria compatível com o regime tributário - das taxas.

O segundo fundamento é o de que o dever de recolher a contraprestação passaria a ser ex lege, uma vez que a taxa estaria vinculada ao uso de um serviço obrigatório por lei. Um contrato de concessão firmado entre concedente e concessionário não seria instrumento suficiente para impor essa obrigação aos usuários. Somente a lei poderia fazer isso.

(...)

Entretanto, esses argumentos não conduzem ao entendimento de que a contraprestação devida pelos serviços de fruição obrigatória teria necessariamente a natureza jurídica de taxa.

(...)

É interessante notar ainda que a compulsoriedade ou não de um serviço não constitui característica do serviço em si. Trata-se, na realidade, de uma condicionante, ou seja, de uma característica do regime jurídico imposto por lei para determinado serviço. Isso claramente não impede a concessão do serviço tido como de fruição obrigatória. A prestação do serviço mediante delegação deverá observar essa condicionante (a fruição compulsória), mas isso não afastará o fato de que eventuais contraprestações serão cobradas na forma de tarifa - que é o regime jurídico compatível com a prestação de serviços públicos em delegação.

(sem ênfase no original)
\end{abstract}

Para o autor, portanto, os argumentos daqueles que tomam a questão da obrigatoriedade de fruição como característica determinante para o afastamento do regime tarifário de uma atividade caem por terra diante de sua análise minuciosa em situações concretas. Vale também lembrar o voto da Exma. Ministra Ellen Gracie, nos autos do RE 201.630, onde entendeu ser aplicável ao serviço de água e esgoto o regime tarifário (lembrando ser esse serviço, tradicionalmente, entendido como de fruição obrigatória).

Frente a este embate, qual critério adotar? Para nós é possível a delegação de serviço cuja fruição é compulsória (água e esgoto, por exemplo) ${ }^{56}$. Mas, mesmo quando

\footnotetext{
${ }^{55}$ Op. Cit., pp. 52/54.

${ }^{56}$ Neste sentido, Alexandre Santos de Aragão: "Houve parte da doutrina que entendeu que, por essas razões, os serviços públicos obrigatórios, ainda que de natureza econômica, como a coleta de lixo domiciliar e a água canalizada em alguns municípios, não poderiam ser objeto de delegações à iniciativa privada, ou, segundo outros, ainda que pudessem, estariam de qualquer forma sujeitos às limitações constitucionais ao poder de tributar.
} 
o Estado diretamente presta atividade desta natureza, nos parece possível a adoção do regime tarifário. A opção pela cobrança da contraprestação de um serviço diretamente executado pelo Estado, por taxa ou tarifa, é política. Cabe à lei que determina seja uma atividade prestada escolher qual o regime de custeio irá adotar. Poderá apontar pela gratuidade do serviço ao usuário (como é a coleta de lixo). É possível também vislumbrar um cenário onde a flexibilidade e dinamicidade na sistemática remuneratória sejam exigidas, adotando o regime tarifário. De outra feita, poderá idealizar ainda a busca por garantias asseguradas apenas pelo regime das taxas. Este critério é o por nós adotado, como forma de escolha da natureza remuneratória do agente executor de serviço público.

Mas ainda não está resolvida a questão. Resta saber se o fato de estar apenas disponível o serviço é fator determinante na classificação de uma atividade como passível de taxa ou tarifa. Neste sentido, é passível de taxa os serviços apenas disponibilizados, mesmo sem a efetiva certeza da real utilização do mesmo. Isso porque o art. 145 da Constituição autoriza a cobrança, via taxa, por serviço meramente disponibilizado ${ }^{57}$.

O mesmo não ocorre com as tarifas. Não há previsão legal acerca da possibilidade de cobrança, por parte do prestador da atividade, apenas e tão somente pela sua disponibilização. Deve existir uma relação direta entre prestador e usuário do serviço. Mesmo nos serviços prestados em rede (onde é comum a cobrança da "assinatura"), existe um vínculo material ou formal direto, permitindo a incidência de tal valor pela mera disposição do potencial de uso.

Sustentamos, ao revés, que o art. 175 da CF representa uma exceção ao regime tributário previsto pela Constituição para os serviços públicos remunerados por taxa, de forma que, sempre que o serviço público (compulsório ou não) tiver sido concedido, a sua remuneração se dará por tarifas". (ARAGÃO, Alexandre Santos de. Curso de direito administrativo. Rio de Janeiro: Forense, 2012, p. 412).

${ }^{57}$ Sobre os conceitos de efetivamente utilizados ou potencialmente disponibilizados, vale a leitura do art. 79 do Código Tributário Nacional:

Art. 79. Os serviços públicos a que se refere o artigo 77 consideram-se: I - utilizados pelo contribuinte:

a) Efetivamente, quando por ele usufruídos a qualquer título;

b) Potencialmente, quando, sendo de utilização compulsória, sejam postos à sua disposição mediante atividade administrativa em efetivo funcionamento;

II - específicos, quando possam ser destacados em unidades autônomas de intervenção, de utilidade ou de necessidade públicas;

III - divisíveis, quando suscetíveis de utilização, separadamente, por parte de cada um dos seus usuários. 
Do todo quanto acima exposto, chegamos à seguinte conclusão:

1) O exercício do poder de polícia dará ensejo à cobrança de TAXA.

2) A prestação de serviço público por particular dará ensejo à cobrança de TARIFA.

3) A prestação de serviço público diretamente pelo Estado dará ensejo à cobrança de TAXA ou TARIFA, sendo definida a espécie por opção política da lei que determinou a prestação do serviço.

4) A cobrança de TARIFA pressupõe deter o usuário, com o prestador do serviço, uma relação direta, a ela se sujeitando por força de um vínculo material ou formal.

5) A cobrança pela simples disponibilização do serviço, sem a efetiva fruição ou existência de um vínculo entre prestador e usuário, se dá por intermédio de TAXA.

Por fim, vale apenas ressaltar que, seguindo entendimento exarado pelo C.

Supremo Tribunal Federal, adotamos como sinônimos "tarifa" e "preço público":

Processo: AI 749940 RS

Relator(a): Min. MARCO AURÉLIO

Julgamento:31/07/2012

Publicação: DJe-156 DIVULG 08/08/2012 PUBLIC 09/08/2012

Parte(s): DEPARTAMENTO MUNICIPAL DE ÁGUA E ESGOTOS - DMAE

JORGE LUIZ NEVES SARAIVA E OUTRO(A/S)

FÁBIO DA SILVA SANTANA

\section{Decisão}

TARIFA X TAXA - ÁGUA E ESGOTO - PRECEDENTES - RECURSO EXTRAORDINÁRIO - PROVIMENTO. 1. Discute-se, na espécie, a natureza jurídica da remuneração do serviço de esgoto prestado por concessionária de serviço público. 2. A jurisprudência desta Corte é no sentido de ter como preço público e, portanto, tarifa, o quantitativo cobrado a título de água e esgoto. Confiram com os seguintes precedentes: Recursos Extraordinários $\mathrm{n}^{\circ} \mathrm{s} 54.194,54.491$ e 77.162, relatados pelos ministros Luis Gallotti, Hermes Lima e Leitão de Abreu, com acórdãos publicados nos Diários da Justiça de 28 de novembro e 17 de dezembro, ambos de 1963 e 24 de maio de 1977, respectivamente. Ve-se, assim, que o decidido não está em harmonia com a óptica emprestada à espécie. 3. Ante o quadro, conheço deste agravo e o provejo, consignando o enquadramento do extraordinário no permissivo da alínea "a" do inciso III do artigo 102 da Constituição Federal. Diante dos precedentes, aciono o disposto nos artigos $544, \S \S 3^{\circ}$ e $4^{\circ}$, e 557, $\S 1^{\circ}$-A, do Código do Processo Civil e julgo, desde logo, o recurso, conhecendo-o e provendo-o para, reformando o acórdão de origem, assentar a exigibilidade da tarifa cobrada a título de remuneração do serviço de abastecimento de água e coleta de esgotos. 4. Publiquem. Brasília, 31 de julho de 2012. Ministro MARCO AURÉLIO - Relator.

(grifamos) 


\subsection{NATUREZA JURÍDICA}

Muito se discute acerca da natureza da tarifa. Alguns defendem terem elas natureza puramente contratual, regidas, portanto, pelo disposto no pacto que deu origem à delegação da atividade. Estamos a tratar, neste particular, das tarifas cobradas por serviços públicos delegados à prestação por particulares. Quando prestados diretamente pelo Estado, mesmo na hipótese de adoção do regime tarifário, a natureza não é contratual, pois não há contrato.

Nas concessões, ao se sustentar tal natureza, vislumbra-se o dever do Poder Concedente em manter o seu equilíbrio econômico-financeiro. Estaria na tarifa, com os reajustes pactuados, a efetiva garantia do particular à manutenção da equação inicialmente contratada. A natureza contratual vedaria, neste sentido, a alteração da tarifa, senão quando em comum acordo das partes.

Mas não nos parece ser essa natureza a que melhor se coaduna com a realidade. Os serviços públicos são atividades típicas da Administração, restando a ela autorizada a delegação à execução por particulares. O Estado continuará titular da atividade, mesmo quando não diretamente a executá-la. Isso não retira de suas mãos algumas prerrogativas. Visando o interesse público, é legítimo que continue a deter totais condições de ingerência sobre a mesma, mantido o dever de sustentar o equilíbrio do inicialmente pactuado com o particular.

Neste sentido, parece-nos razoável a atuação do Poder Concedente diretamente sobre os aspectos da concessão relacionados com o serviço em si, devendo respeitar as particularidades financeiras do que fora avençado. Pode, assim, impor alterações unilaterais no valor das tarifas. 
Toda vez que houver ingerências do Poder Concedente na tarifa de um serviço, e estas impactarem o equilíbrio econômico-financeiro da concessão, assiste ao particular o direito de sua imediata recomposição. Todavia, esse direito não é suficiente para tirar das mãos do titular do serviço o poder de nele influir, no tocante especificamente à forma de executar a atividade delegada (aí incluída a disposição do valor da tarifa, mantendo-a sempre módica). Ao tratar da fixação do que chama de tarifa ótima, Egon Bockmann Moreira ${ }^{58}$ fez constar:

Por conseguinte, a fixação da tarifa ótima é antes dever estatal que prerrogativa privada. Ela é estabelecida em vista do que se pretende politicamente daquele projeto de interesse público primário - não em razão das perspectivas dos investidores. Por isso se pode afirmar que a definição do regime tarifário é mais estatutária que contratual, mais administrativa que empresarial - enfim, mais política que jurídica. Este regime jurídico que advém de uma decisão política deve ser mantido estável durante toda a relação contratual.

Alterações nas tarifas, portanto, dão ensejo à obrigação de manutenção do equilíbrio econômico-financeiro das concessões; todavia, detêm natureza regulamentar, pois pertencentes ao campo suscetível de alterações unilaterais. Neste sentido são as lições de Carlos Manuel Grecco59:

La tarifa es essencialmente un acto unilateral de la Administración. Es un acto reglamentario propiamente dicho: a este título, sólo puede ser pues, obra exclusiva de la Administración. Las leyes establecen la autoridad administrativa competente para homologar las tarifas y el procedimiento a seguir para establecerlas. Estos textos deben ser interpretados siempre teniendo en cuenta la naturaleza jurídica reglamentaria de la tarifa en cuanto elemento esencial de la organización del servicio público.

\subsection{TARIFA E LUCRO}

\footnotetext{
${ }^{58}$ MOREIRA, Egon Bockmann. Direito das concessões de serviço público - inteligência da lei 8.987/1995 (parte geral). São Paulo: Malheiros, 2010, pp. 331/332.

${ }_{59}$ GRECCO, Carlos Manuel. Potestad tarifaria, control estatal y tutela del usuario. In: MUNOZ, Guillermo Andrés; GRECCO, Carlos Manuel. Fragmentos y testimonios del derecho administrativo. Buenos Aires: AdHoc, 1999, p. 428.
} 
Sendo o concessionário um agente econômico, é a obtenção de mais-valia o móvel que o leva a assumir os encargos de prestar um serviço público. Assim, deve a remuneração propiciar condições deste agente obter lucro com a exploração da atividade a ele delegada.

Há casos em que a remuneração do concessionário advém não só das tarifas, mas também de receitas secundárias (impactando a composição tarifária). Todavia, para ilustrar os componentes econômicos que devem ser suportados pela tarifa, imaginemos uma concessão onde seja esta a única fonte de remuneração do particular. Deve incorporar as seguintes parcelas de custos: 1) amortização dos investimentos em infraestrutura necessária à prestação da atividade; 2) custos operacionais e de manutenção; 3) custos fiscais; 4) lucro.

Este lucro será calibrado pela proposta comercial elaborada por ocasião da licitação em que se delegou a atividade. Contudo, nem sempre o critério de escolha do concessionário é o de oferecimento da menor tarifa. Por vezes a tarifa é fixada pelo edital, sendo vencedor o detentor da proposta de maior repasse ao Poder Concedente. Possíveis também outras formas, desde que viáveis perante o serviço a ser delegado, e que permitam a manutenção das tarifas em patamares considerados módicos.

Em qualquer das formatações é possível que, com o tempo, a parcela de lucro (estabelecida pela proposta vencedora do certame) venha a se alterar. Com o ganho em eficiência os custos operacionais tendem a diminuir, criando um cenário onde a tarifa então praticada permite a obtenção de lucro em patamares superiores ao estabelecido no início do contrato. 
Surge então a discussão acerca da necessidade de repartição desse ganho - e mais, se repartível apenas com o Poder Concedente ou com todos os cidadãos. Neste particular, válido o posicionamento de Egon Bockmann Moreira ${ }^{60}$ :

\begin{abstract}
Inicialmente pode-se afirmar que a remuneração deve ser adequada à obra e ao serviço, proporcional ao valor investido e ao risco assumido pelo empresário. Nos serviços públicos o regime de preços deve ser apto não apenas a pagar o investidor, mas em especial a incrementar o bem-estar social. Como boa parte dos usuários é constituída de pessoas menos favorecidas que os acionistas do empreendimento, é mais que justo que recebam parcela do potencial de ganhos destes. Portanto, está-se diante de projetos concessionários que significam políticas públicas de distribuição de renda. Ora, as políticas públicas são avaliadas através dos reflexos que têm no excedente social e sua distribuição. Um contrato de concessão de serviço público bem ajustado pode tornar-se um eficaz instrumento de distribuição de renda.

(...)

Os benefícios econômicos do empreendimento hão de ser repartidos com os usuários (e terceiros), evitando-se ganhos desproporcionais por parte do concessionário - tarefa cuja concretização e supervisão cabe ao concedente (e/ou regulador), desde o momento da configuração do edital. Daí a possibilidade de instrumentos técnicos que permitam a efetiva partilha dos ganhos de performance do concessionário.
\end{abstract}

Em regra o aumento exponencial na parcela de lucro do concessionário advém de ganhos oriundos da própria prestação do serviço. O know-how adquirido e o desenvolvimento de novas tecnologias permitem ganhos de eficiência que impactam os custos operacionais, aumentando o resultado final. Surge a questão: não fosse a possibilidade de aumento de sua mais-valia, teria o concessionário interesse em implementar medidas visando majorar seu lucro (considerando, ao final, ter que repartilo)?

Nas atividades delegadas onde existe concorrência (telecomunicações, por exemplo), a busca pela eficiência, pela atualização da tecnologia, pela elevação dos padrões de qualidade está intimamente ligada à capacidade do agente em se manter "vivo" no mercado em que atua. Oferecendo menor qualidade ou maior preço a migração dos usuários para o concorrente é natural e saudável, pois impõe a necessária manutenção, por toda a concessão, de um serviço moderno e de qualidade.

${ }^{60}$ Op. Cit., pp. 335/336. 
O mesmo não acontece nas atividades prestadas em situação de monopólio natural $^{61}$. Nestas hipóteses o concessionário não se vê forçado a aprimorar sua atuação, pois não existe pressão concorrencial. Cabe então ao Poder Concedente estabelecer metas de qualidade e atualização a serem atingidas pelo particular, sob pena de estagnação do serviço. Vale lembrar ser possível estabelecer, em determinadas hipóteses, remuneração progressiva, atrelada ao desempenho do concessionário.

O fato é que o lucro é a razão de existir do concessionário de serviço público. Irá sempre persegui-lo em patamares superiores aos inicialmente convencionados. Eventuais ganhos deverão ser partilhados, tanto com o Poder Concedente, quanto com os usuários e terceiros, pois a atividade explorada é titularizada pelo Estado.

Haverá sempre uma tendência de aumento da parcela de lucro, que compõe a tarifa, mas não seria legítimo permitir fosse o mesmo capturado apenas por um dos atores, considerando a existência de vários necessários à viabilidade do negócio.

\subsection{SISTEMA DE FIXAÇÃO DAS TARIFAS}

Não é missão das mais singelas a de se estabelecer qual valor é o mais adequado a título de contraprestação por um serviço público. Diversos aspectos devem ser considerados, visando sempre a estabilidade da concessão. Contudo, o norte principal deste desiderato é a modicidade tarifária, que se sobrepõe à garantia do equilíbrio econômicofinanceiro. Quando em desequilíbrio uma concessão, o possível aumento da tarifa para

\footnotetext{
${ }^{61} \mathrm{O}$ monopólio natural existe naquelas hipóteses em que, havendo diversos prestadores do mesmo serviço, os preços seriam superiores aos praticados caso houvesse apenas um. Ocorre nos casos onde os investimentos necessários à execução da atividade delegada são deveras elevados, acarretando uma impossibilidade de custeio de duas estruturas. Ademais, é possível imaginar também monopólios naturais em atividades cuja possibilidade de fruição de dois ou mais sistemas trouxessem inconvenientes consideráveis aos usuários (imagine-se duas ou mais prestadoras de serviço de fornecimento de gás e o ônus da escavação das ruas para instalação de outras redes de tubulação).
} 
restabelecimento da equação inicial encontra limites nos valores considerados módicos para a mesma, cabendo ao Poder Concedente a incumbência de avaliar, perante o cenário econômico/social, quais serão.

Ainda sobre a fixação das tarifas, vejamos o que dispõe a Lei Federal $n^{\circ}$ 8.987/1995:

Art. $9^{\circ}$ A tarifa do serviço público concedido será fixada pelo preço da proposta vencedora da licitação e preservada pelas regras de revisão previstas nesta Lei, no edital e no contrato.

Do dispositivo acima transcrito é possível se chegar à seguinte conclusão: as tarifas são fixadas pelo licitante vencedor, ao formular sua proposta nos autos do processo licitatório precedente à delegação da atividade. Nesta lógica, a Administração, por intermédio do edital de licitação, anuncia uma série de encargos e obrigações que deverão ser assumidos e executados pelo particular, questionando qual tarifa lhe é conveniente para assunção dos ônus pré-noticiados.

Mas nem sempre é assim. Por vezes o edital já anuncia o valor da tarifa a ser praticada, adotando como critério de classificação das propostas aquela que maior valor de outorga apresentar. Outorga deverá ser entendida, nesta seara, como o preço pago pelo particular ao Poder Público pelo direito de explorar a atividade. Diferentemente da primeira situação (era o particular quem fixava o valor da tarifa), nesta hipótese é a Administração quem dirá qual o seu valor adequado, sempre pautada pelo conflito "modicidade tarifária X estabilidade financeira" da concessão. Poderá também o edital prever a combinação desses critérios como forma de julgamento das propostas (vide art. 15 da Lei Federal nº. 8.987/1995).

Outro aspecto que merece ser considerado no momento de fixação da tarifa não se refere exatamente aos custos do serviço em si, mas na forma como o mesmo será usufruído. Uma tarifa muito baixa acarreta mau uso do serviço. O fornecimento de água é 
um exemplo clássico: se muito barata o uso tende a ser irracional, pois o usuário não irá envidar esforços no sentido de evitar desperdícios.

Por fim, parece-nos relevante que o Poder Público almeje, nessa árdua missão de fixar o valor justo e adequado, criar condições de desenvolver a atividade concedida, usando a tarifa como meio de implementação de políticas públicas. Ao tratar da fixação das tarifas nas concessões comuns, Egon Bockmann Moreira ${ }^{62}$ assim averbou:

Há, quando menos, dois ângulos nos quais deve ser analisada a tarifa ótima nas concessões comuns: (i) se ela permite a instalação de projeto autossustentável; (ii) se ela é equânime, no sentido de promover a distribuição adequada dos custos e benefícios entre concessionário e usuários. As tarifas não podem ser nem muito baixas (sob pena não só de inviabilizar a autossustentabilidade do projeto, mas especialmente em vista da frustração do incentivo para que os usuários consumam adequadamente o serviço) nem muito altas (sob pena de inviabilizar o acesso ao serviço público ao maior número de usuários).

Uma preocupação existente até o advento das parcerias público-privadas era a de saber se o serviço concedido, remunerando-se o particular com tarifas e possíveis receitas alternativas, era autossustentável. Não que subsídios não fossem possíveis naquela conjuntura. Mas a prática de oferecimento de contraprestação estatal direta ao concessionário de serviço público surgiu mais recentemente, com a edição da Lei Federal $n^{\circ}$. 11.079/2004. Nascia então a possibilidade de implementação de projetos nem sempre autossustentáveis, permitindo que o Poder Público, ao vislumbrar uma concessão, pudesse complementar as receitas do particular, mantendo a modicidade tarifária.

Raiou então um novo mundo de possibilidades. A Administração pode hoje implementar projetos insustentáveis economicamente, mas considerados essenciais, arcando parcialmente com seus custos de execução. Caso a modicidade imponha um teto tarifário que não permita o custeio da operação o Poder Público pode complementá-lo, fazendo hoje, de atividades antes economicamente indelegáveis, plenamente viáveis de execução em regime de concessão.

${ }^{62}$ Op. Cit., p. 331. 
Com relação à competência para fixação das tarifas, vale lembrar ter a Constituição Federal reservado à lei a incumbência de dispor sobre política tarifária $(\mathrm{CF}$, art. 175, Parágrafo único, III). Cumpre então ao legislativo do ente titular da atividade a ser delegada traçar os parâmetros dessa política, mas não efetivamente seu valor (a depender do "desenho" concessório e do momento em que será concretizada a concessão). A Lei Federal $n^{\circ}$. 8.987/1995 trouxe um capítulo (Capítulo IV) sobre política tarifária. Não impede os legislativos estaduais e municipais tratarem da matéria; todavia, apresenta um norte a ser seguido, servindo como regra matriz.

\subsubsection{Princípio da modicidade tarifária}

Constam do $\S 1^{\circ}$ do art. $6^{\circ}$ da Lei Federal $n^{\circ} .8 .987 / 1995$ as condições a serem satisfeita para que um serviço público seja considerado adequado ao pleno atendimento dos usuários. Percebe-se ser a regularidade, a continuidade, a eficiência, a segurança, a atualidade, a generalidade e a cortesia na sua prestação seus preceitos essenciais. Todavia, é na modicidade tarifária onde reside, a nosso ver, o ponto crucial de uma concessão. Dela se extrai qual espécie de concessão será adotada (se comum, patrocinada ou administrativa). Nela se encontram os limites de investimento e participação do agente privado.

Não há previsão legal ou constitucional determinando sejam os serviços públicos gratuitos. Aliás, existe sim uma lógica interpretativa que induz à conclusão de que os serviços colocados à disposição pelo Poder Público poderão ser cobrados. Salvo o serviço público de ensino (art. 206, IV da CF) e o transporte público para idoso (art. 230, § $2^{\circ}$ da $\mathrm{CF}$ ), onde a gratuidade é exigida pela Constituição, implícita está a possibilidade de cobrança pelos demais. 
A conclusão acima não autoriza, todavia, seja o valor cobrado desproporcional à atividade disponibilizada. Isso porque é dever da Administração tutelar os interesses públicos, resguardando os interesses de toda a coletividade, sem prejuízo de qualquer esfera da população. Aliás, é obrigação do Estado promover a inclusão dos menos favorecidos, praticando políticas que permitam a diminuição das desigualdades, em busca de uma melhor distribuição de renda e de uma sociedade mais equânime e solidária.

Nesta esteira, a universalidade (ou generalidade), alçada à categoria de princípio dos serviços públicos, só pode ser alcançada com a modicidade tarifária. Uma tarifa não módica impossibilita a fruição da atividade por considerável parcela da população $^{63}$. A modicidade tarifária obriga o Poder Concedente a manter as tarifas em patamares que permitam o serviço estar acessível ao maior número possível de usuários. Ao tratar do tema assim fez constar Marçal Justen Filho ${ }^{64}$ :

\begin{abstract}
A modicidade tarifária significa a menor tarifa possível, em vista dos custos necessários à oferta do serviço adequado. A modicidade tarifária pode afetar a própria decisão quanto à concepção do serviço público. Não terá cabimento conceber um serviço tão sofisticado que o custo torne inviável aos usuários fruir dos benefícios.
\end{abstract}

Percebe-se estar, até mesmo, a qualidade do serviço atrelada à modicidade da tarifa. Se a atualidade importar em custos que onerem, em demasia, a tarifa, é razoável que o serviço não seja prestado com a utilização das técnicas e equipamentos mais modernos (é o caso do transporte público por ônibus equipados com ar-condicionado).

Por fim, vale lembrar que a modicidade deve ser analisada no contexto do serviço, ou seja, examinando a natureza da atividade, seu público alvo e sua capacidade

\footnotetext{
${ }^{63}$ Infelizmente o Brasil ainda é uma nação de miseráveis. O relatório do Desenvolvimento Humano 2011, divulgado pelo Programa das Nações Unidas para o Desenvolvimento (Pnud), classifica o Brasil na 84 ${ }^{\mathrm{a}}$ posição entre 187 países avaliados pelo índice. O Índice de Desenvolvimento Humano (IDH) do Brasil em 2011 é de 0,718 na escala que vai de 0 a 1 . O índice é usado como referência da qualidade de vida e desenvolvimento sem se prender apenas em índices econômicos. O país com mais alto IDH em 2011 é a Noruega, que alcançou a marca de 0,943. Os cinco primeiros colocados do ranking são, pela ordem: Noruega, Austrália, Holanda, Estados Unidos e Nova Zelândia. Segundo o Pnud, o pior IDH entre os países avaliados é o da República Democrática do Congo, com índice 0,286. Os cinco últimos são: Chade, Moçambique, Burundi, Níger e República Democrática do Congo.

${ }^{64}$ Op. Cit., p. 702.
} 
contributiva. No transporte público a maior parte dos usuários é composta de pessoas que não dispõem de outro meio de locomoção (automóvel). Presume-se que considerável parcela usuária deste serviço detém baixo poder aquisitivo. Diferente nas concessões de rodovia, nas quais é pressuposto do uso a detenção de meio próprio de locomoção (automóvel, motocicleta, ônibus ou caminhão), levando-se à conclusão de que, relativamente ao transporte público, pessoas mais abonadas utilizarão diretamente este serviço.

\subsubsection{A complexa questão da universalidade do serviço}

Como acima explicitado, é obrigação do Poder Concedente orientar a lógica do projeto a ser concedido, no sentido de possibilitar sua fruição pelo maior número de pessoas possível. Para tal desiderato estará balizado pelo princípio da modicidade tarifária, impeditivo de tarifas atentatórias à universalidade do serviço.

Contudo, nem sempre é possível conceber modelo econômico-financeiro que viabilize a concessão da atividade, caso a tarifa cobrada do usuário seja proporcional ao quantum efetivamente utilizado do serviço. Tornou-se então comum em algumas atividades a repartição total dos custos, criando sistemática de compensação tarifária conhecida por subsídio cruzado. No transporte público tal modelo é nítido e exemplificativo: aquele que adentra ao ônibus para andar poucos quilômetros paga a mesma tarifa daquele que ingressa no ponto inicial e vai até a parada final do coletivo. Ou seja, quem pouco utilizou do serviço custeou o usuário que demandou mais da concessionária.

Essa lógica de partilha dos custos dentre todos os usuários visa universalizar o serviço, tornando-o acessível a um maior número de pessoas (mesmo que impondo um ônus aparentemente injusto àquele que "paga mais por menos"). Poderia o Estado custear, 
com recursos próprios, a parcela deficitária, não impingindo a um usuário o dever de suportar parcela das despesas de outro? Sim, contudo estaria comprometendo recursos que poderiam ser destinados a outros fins. A opção pela adoção do subsídio cruzado, portanto, insere-se no campo das decisões políticas.

$\mathrm{Na}$ adoção desta prática, todavia, deve a Administração atentar para o fato de que, por vezes, um subsídio cruzado pode anular o efeito de outro ("dá com uma mão e tira com a outra"). A redução da conta de luz da população mais carente, num sistema de subsídio cruzado, pode majorar a conta dos grandes consumidores (indústrias), repassando tal custo aos seus produtos, culminando com o consumo desses produtos pela mesma população de baixa renda que usufruiu do benefício.

Outra questão polêmica atinente ao tema é saber se é legítima a cobrança de custos de ampliação da rede. O usuário presente estará custeando um sistema que vai beneficiar os futuros usuários. Não nos parece, todavia, ser desprovida de lógica essa prática, pois coerente com os ditames do princípio da solidariedade, insculpidos no art. $3^{\circ}$ da Carta da República.

Para se estabelecer a política tarifária, portanto, deve o Poder Concedente eleger qual será o público alvo do serviço a ser concedido, analisar qual a capacidade contributiva dessa parcela da população e cotejar com o custo estimado da unidade do serviço. Dentro desta moldura deverá conceber o projeto, avaliando qual modelo (concessão comum, patrocinada, administrativa, adoção do sistema de subsídio cruzado, oferecimento de subsídio estatal, incorporação de atividades secundárias no projeto, etc.) é mais adequado à implementação da política pública pretendida.

\subsection{REVISÃO E REAJUSTE}


As concessões, como afirmado alhures, são contratos administrativos que, por vezes, criam obrigações por lapsos temporais bastante elevados. É comum avenças desta natureza por 20 (vinte), 30 (trinta) anos, mesmo porque sua duração está atrelada ao porte de investimentos necessários à construção da infraestrutura e disponibilização de equipamentos necessários à perfeita execução da atividade pretendida.

Nesta esteira, é essencial que o instrumento contratual traga formas de manter estável a remuneração do particular, proporcionando segurança jurídica ao contrato entabulado e garantindo a continuidade e atualidade do serviço. As tarifas, portanto, não são imutáveis - ao contrário, devem se adequar ao contexto da prestação dos serviços por elas remunerados. Neste sentido são as lições de José Roberto Dromi ${ }^{65}$ :

Las tarifas de los servicios públicos no son inmutables, sino un elemento variable, sujeto a las modificaciones que impongan las condiciones en que se prestan los servicios. En consecuencia, la revisión periódica de las tarifas es jurídicamente legítima y económicamente necesaria.

Tanto a revisão quanto o reajuste são formas de alteração do quantum tarifário. Entretanto, não podem ser confundidos, pois são instrumentos diversos de readequação de valores.

Comecemos pelo reajuste: nada mais é do que a restauração do valor, defasado por conta das variações dos preços dos insumos aplicados na execução do serviço. Celso Antônio Bandeira de Mello ${ }^{66}$, em trabalho coordenado por Juan Carlos Cassagne em homenagem ao Professor Miguel S. Marienhoff, foi quem melhor tratou da matéria:

Las cláusulas de reajuste de precios son disposiciones que poseen fórmulas concebidas para preservar de modo fluido, simple y pacífico, el contenido económico-financiero del ajuste.

${ }^{65}$ DROMI, José Roberto. Manual de derecho administrativo. Tomo 1. Buenos Aires: Editorial Astrea, 1987, p. 372 .

${ }^{66}$ MELLO, Celso Antônio Bandeira de. Las cláusulas de reajuste de precios en los contratos administrativos. In: CASSAGNE, Juan Carlos (Coord.). Derecho administrativo, obra coletiva en homenaje al Profesor Miguel S. Marienhoff. Buenos Aires: Ed. Abeledo-Perrot, 1998, p. 912. 
Como la ecuación establecida entre las partes es uma relación de equivalencia entre prestaciones recíprocas, queda entendido que al costo de uma prestación " $\mathrm{x}$ " - que se compone por las obligaciones económicas implicatas en ella y el margen de remuneración del prestador - correspondem los pagos "y" que él resguarda. Esta relación de igualdad concebida por las partes debe ser mantenida. Así, si los costos de los insumos necesarios para la prestación "x" sufren elevaciones constantes - como es frecuente en países de economía no estable - los pagos "y" tienen que incrementarse en la misma proporción, sin que la igualdad denominada "ecuación económico-financiera" deje de existir.

(...)

Es este efecto injusto el que se procura evitar. Por eso es que las cláusulas de reajuste, como su nombre lo indica, establecen fórmulas de ajuste automático del valor de los pagos a la variación del precio de los insumos. Se trata, como se ve, de un mecanismo por el cual se busca mantener incólume, intacta, la igualdad que las partes tuvieron en vista y reciprocamente aceptaron.

Comumente o reajuste se faz através da aplicação de uma fórmula ou um índice econômico, previamente estabelecido no contrato. A periodicidade de sua incidência também deve estar prevista, sendo normalmente anual. Sua implementação depende de simples homologação do Poder Concedente, sendo devida sua aplicação mesmo em caso de variação negativa dos custos que compõem o preço.

Contudo, na prática da advocacia já nos deparamos com situações em que, após o advento do marco temporal de aplicação do reajuste, mesmo provocado, o Poder Concedente se quedou inerte, não implementando a "nova tarifa" ${ }^{67}$. Como interpretar este silêncio? Parece-nos que, nestes casos, estamos diante do silêncio positivo da Administração:

Por vezes a lei atribui efeitos ao silêncio administrativo. Na maioria delas, as normas conferem sentido de negação (chamado, portanto, de silêncio negativo), tendo, desta forma, deslinde negativo o pleito do administrado. Contudo, existem situações que a lei atribui expressamente efeito positivo, concedendo o que fora requerido, após o decurso do prazo da autoridade se manifestar. ${ }^{68}$

\footnotetext{
${ }^{67}$ Nas lições de Arnoldo Wald, Luíza Rangel de Moraes e Alexandre de Mendonça Wald, “a tarifa resultante de reajuste é a mesma tarifa anterior, não significando o reajuste um aumento, nem importando fixação de nova tarifa". (WALD, Arnoldo; MORAES, Luíza Rangel de; WALD, Alexandre de Mendonça. $O$ direito de parceria e a lei de concessões. 2. Ed. São Paulo: Saraiva, 2004, p. 195).

${ }^{68}$ Vide nosso: Silêncio administrativo - o "não ato". In: MEDAUAR, Odete; SCHIRATO, Vitor Rhein (Coords.). Os caminhos do ato administrativo. São Paulo: RT, 2011, p. 205.
} 
Tal conclusão (de que, no silêncio, a aplicação do reajuste está deferida) advém do disposto no inciso $\mathrm{V}$ do art. 29 da Lei Federal $\mathrm{n}^{\circ}$. 8.987/1995, que atribui ao Poder Concedente a incumbência de homologar reajustes. Tal atuação é vinculada e, caso não efetuada, dá ensejo a pleito judicial, onde deve o Estado-juiz, liminarmente, autorizar a aplicação do novo valor.

Já a revisão é procedimento mais complexo e visa atingir outro objetivo. Egon Bockmann Moreira ${ }^{69}$ foi feliz ao expor seu conteúdo:

\begin{abstract}
A revisão significa o procedimento pelo qual se pretende emendar, corrigir ou aperfeiçoar a tarifa praticada. É modo específico de disciplina e controle da tarifa durante todo o prazo contratual. Diz respeito à manutenção do equilíbrio econômico-financeiro sob seu aspecto substancial, com o exame e a reestruturação dos dados cuja combinação configurou a tarifa. Ao contrário do reajuste, não se trata só de mecanismo de manutenção do valor real da tarifa, mas sim de sua (re) avaliação crítica. A revisão é, portanto, um procedimento cooperativo em que concedente (ou regulador) e concessionário renovam alguns dos debates que permitiram a configuração original da tarifa (o que se dá dentro dos limites impostos pelo regime estatutário e contratual). Aqui, o nível e a estrutura da tarifa podem ser reavaliados, bem como a eficiência, a qualidade, e a remuneração adequada - aproveitando-se a experiência construída no próprio projeto, com o intuito de permitir seu aperfeiçoamento.
\end{abstract}

Nos termos do art. $9^{\circ}$, caput, da Lei Federal n. 8.987/1995, a tarifa do serviço público concedido será preservada pelas regras de revisão previstas na própria lei, no edital e no contrato. $\mathrm{O} \S 3^{\circ}$ do mesmo artigo dispõe que, ressalvados os impostos sobre a renda, a criação, alteração ou extinção de quaisquer tributos ou encargos legais, após a apresentação da proposta, havendo comprovação do seu impacto, dará ensejo à revisão da tarifa, para mais ou para menos, conforme o caso. Por fim, o $\S 4^{\circ}$ estabelece que, havendo alteração unilateral do contrato que afete o seu inicial equilíbrio econômico-financeiro, o poder concedente deverá restabelecê-lo, concomitantemente à alteração.

Resta claro, portanto, que à recomposição da equação econômico-financeira do contrato dá-se o nome de revisão. Sempre que o Poder Público adequa a tarifa a uma nova realidade fática do serviço estamos diante de uma revisão tarifária. Essa revisão pode

${ }^{69}$ Op. Cit., p. 360. 
ser circunstancial (se concomitante à ocorrência de um evento específico do qual decorra desequilíbrio) ou periódica.

A revisão circunstancial pode se dar de diversas formas: alteração do valor da tarifa, modificação dos encargos das partes, ampliação ou diminuição do tempo de concessão, inclusão ou exclusão de subsídio cruzado na operação da atividade, etc. Basta a mudança vislumbrada ser capaz de devolver ao contrato seu equilíbrio.

Várias formas também podem ser concebidas pelo Poder Público no intuito de permitir revisões periódicas da tarifa. Cada atividade apresenta particularidades capazes de dar ensejo à criação de novas sistemáticas de revisão. Atualmente nos parece ser muito eficiente, apesar de não aplicável a qualquer modelo concessório, a sistemática conhecida por "tarifa teto" (também denominada na doutrina por "price cap"70). Neste sistema, o Poder Concedente estabelece um valor máximo, ficando facultado ao concessionário praticar qualquer tarifa abaixo deste limite. Implementou-se assim uma flexibilização do regime tarifário, permitindo ao executor do serviço otimizar seus ganhos, variando o valor da tarifa de acordo com sua estratégia comercial. Poderá reduzi-la sensivelmente, buscando atrair usuários. Poderá, de outra feita, majorá-la ao seu limite, ocasionando a consequente diminuição de usuários e a quantidade de serviço utilizada. Enfim, deverá estabelecer a estratégia que lhe parecer mais coerente e adequada, tornando viável a revisão tarifária a qualquer tempo.

Conclui-se, portanto, que a concessão, tal como idealizada na Lei Federal $n^{\circ}$. 8.987/1995, está permeada de incentivos à manutenção do equilíbrio econômicofinanceiro inicialmente pactuado. Reajustes e revisões tarifárias são instrumentos de estabilização desse equilíbrio. Sua aplicação, todavia, deve sempre considerar a modicidade tarifária. Se atentarem contra tal princípio, suas implementações não restarão autorizadas.

\footnotetext{
${ }^{70}$ Tal sistema, concebido pelo economista Stephen Littlechild, teve sua aplicação iniciada nos idos da década de 80 do século passado, no Reino Unido.
} 


\section{RECEITAS SECUNDÁRIAS}

6.1. Quais são (alternativas X complementares $\mathrm{X}$ acessórias $\mathrm{X}$ projetos associados); 6.2. Legitimidade do delegatário em recebê-las; 6.3. O impacto social; 6.4. Possibilidade de remuneração do particular exclusivamente por este meio; 6.5. Flexibilidade e reequilíbrio contratual.

A forma tradicional de remuneração do concessionário de serviço público é a cobrança de tarifa dos usuários. Todavia, por vezes outras utilidades econômicas podem ser extraídas do projeto, atreladas ou não ao serviço prestado, possibilitando ao executor da atividade obter recursos que componham sua remuneração.

Mesmo a doutrina mais tradicional, que entende se dar a remuneração nas concessões de serviços públicos basicamente pela tarifa (por força do disposto no art. 175 da Constituição Federal, que se refere à política tarifária - vide capítulo 7, item 7.2.), não 
afasta a possibilidade da existência de receitas marginais, quando atreladas à própria atividade concedida:

Em geral, o concessionário de serviço público (ou da obra pública) explora o serviço (ou a obra pública) mediante tarifas que cobra diretamente dos usuários, sendo daí que extrai, basicamente, a remuneração que lhe corresponde. Isto não exclui a possibilidade de que sejam também previstas outras fontes de recursos para compor-lhe a remuneração.

(MELlO, Celso Antônio Bandeira de. Curso de direito administrativo. 21. Ed. São Paulo: Malheiros, 2006, pp. 702/703).

Mas em algumas situações os recursos provenientes destas formas "secundárias" de remuneração podem superar os valores oriundos das tarifas. Adiante serão analisadas suas espécies, especificidades e implicações nas concessões de serviços públicos.

\subsection{QUAIS SÃO (ALTERNATIVAS X COMPLEMENTARES X ACESSÓRIAS X PROJETOS ASSOCIADOS)}

As "receitas secundárias", expressão usada doravante como gênero a englobar diversas espécies, podem ser divididas em 4 (quatro):

Lei Federal no. 8.987/1995:

Art. 11. No atendimento às peculiaridades de cada serviço público, poderá o poder concedente prever, em favor da concessionária, no edital de licitação, a possibilidade de outras fontes provenientes de receitas alternativas, complementares, acessórias ou de projetos associados, com ou sem exclusividade, com vistas a favorecer a modicidade das tarifas, observado o disposto no art. 17 desta Lei.

Parágrafo único. As fontes de receita previstas neste artigo serão obrigatoriamente consideradas para a aferição do inicial equilíbrio econômico-financeiro do contrato.

(sem ênfase no original)

$\mathrm{Na}$ maioria das vezes a doutrina trata conjuntamente destas espécies de receitas, pois todas visam um mesmo fim: a modicidade das tarifas. Essa finalidade consta 
da própria lei, dando a entender que sempre almejarão complementar a receita oriunda das tarifas, nunca substituí-la.

Todas as 4 (quatro) espécies de receitas contêm um núcleo comum: seus frutos irão compor o equilíbrio econômico-financeiro da concessão. Não se está aqui a dizer, todavia, que deverão decorrer de atividades adjacentes ao serviço prestado. Pelo contrário: é possível a obtenção de receita marginal decorrente de utilidade totalmente alheia ao serviço delegado. Neste sentido são as lições de Fernando Vernalha Guimarães ${ }^{71}$ :

\begin{abstract}
Parecem-se excessivas, então, as teses restritivas, que vêem na dicção do artigo 11 prescrição autorizativa para a integração de recursos oriundos de fontes necessariamente relacionadas ou associadas ao projeto da concessão (o que pressupõe um vínculo material com a prestação do serviço público). A meu ver, restringir o acesso a fontes alternativas de receita àquelas relacionadas materialmente ao projeto da concessão em si é podar o alcance abrangente da permissão veiculada pelo dispositivo legal.
\end{abstract}

Desta forma, pode-se concluir que a lei, ao se referir a projetos associados, deu a entender existir uma interface desta espécie de "receita secundária" com a atividade delegada. Haverá, nesta hipótese, um vínculo material com a execução da concessão, sem se constituir na prestação do serviço público em si. Visando ilustrar tal situação podemos citar as recentes concessões de serviços públicos para ampliação, manutenção e exploração dos Aeroportos Internacionais de Brasília, Campinas e Guarulhos. A remuneração ordinária da concessionária advém do pagamento das tarifas aeroportuárias. Entretanto, previa o edital que receitas não tarifárias comporiam a remuneração do licitante vencedor, oriundas da exploração de atividades econômicas realizadas no Complexo Aeroportuário exploração de espaços publicitários, por exemplo.

Portanto, pode-se definir como projetos associados a espécie de "receita secundária" oriunda de externalidades positivas decorrentes da prestação de serviços concedida, desde que não se confunda com a atividade fim, embora dela dependa.

\footnotetext{
${ }^{71}$ GUIMARÃES, Fernando Vernalha. As receitas alternativas nas concessões de serviços públicos no direito brasileiro. In: Revista de direito público da economia. Belo Horizonte: Fórum, vol. 6, nº. 21, janeiro 2008.
} 
$\mathrm{Na}$ mesma esteira seguem as receitas acessórias. Tomado como verdadeiro o raciocínio de que o acessório segue o principal, essa espécie de "receita secundária" acompanha a atividade delegada. Aliás, está a ela intimamente ligada, sem a qual sequer existiria. Como exemplo podemos citar o oferecimento de seguro-viagem (receita acessória) ao passageiro de ônibus interestadual (que paga tarifa para aquisição da passagem).

Diferentemente dessas duas espécies acima explicitadas, as receitas alternativas e as receitas complementares podem, ou não, apresentar vinculação direta com a concessão. Ao comentar a redação do art. 11 da Lei de Concessões Fernando Vernalha Guimarães $^{72}$ fez notar:

\begin{abstract}
Observe-se que a interpretação gramatical do preceito não favorece a tese contrária. A letra do artigo prevê a possibilidade jurídica de outras fontes (que não a receita tarifária) a integrar a remuneração do concessionário, "provenientes de receitas alternativas, complementares, acessórias ou de projetos associados". Não há alusão a que as oportunidades lucrativas tenham vinculação com o projeto da concessão. Refere-se a receitas alternativas, complementares ou de projetos associados. Se a noção de projetos associados pode remeter à ideia de projetos dotados de relação funcional com a concessão, o mesmo não se pode pressupor quanto à previsão de receitas alternativas ou complementares. Aliás, a inserção expressa de todas estas hipóteses indica, sob pena de presumir o caráter supérfluo da prescrição legal, desafiando princípio hermenêutico fundamental, que cada qual remete a situação particular e inconfundível. Portanto, a situação de receitas decorrentes de projetos associados configura hipótese distinta das situações de receitas alternativas e complementares - pressupondo-se essas, então, não-dotadas de relação direta e funcional com o projeto da concessão.
\end{abstract}

Não há obrigatoriamente o exercício de uma atividade atrelada ao serviço concedido, como ocorre nos projetos associados. Nas receitas alternativas não haverá uma ampliação do objeto da concessão, mas sim uma mudança na forma de remuneração do concessionário. Decorre de sua denominação a obviedade de que, alternativamente à matriz remuneratória tradicional (tarifa), uma outra fará suas vezes. Desta forma, a ideia é a de que todo o serviço seja custeado por esta nova forma de receita. E, assim ocorrendo, deixará de ser uma receita secundária e passará a ser a fonte primordial de recursos do prestador do serviço delegado.

${ }^{72}$ Op. Cit., p. 126. 
Por fim, as receitas complementares são aquelas que, complementarmente à tarifa, integram a remuneração do concessionário. Não objetivam extinguir sua cobrança; visam apenas sua modicidade.

\subsection{LEGITIMIDADE DO DELEGATÁRIO EM RECEBÊ-LAS}

As receitas secundárias decorrem, por vezes, de utilidades que se apresentam como viáveis economicamente apenas no curso da concessão. Aquelas existentes ou previsíveis no momento da licitação recebem um tratamento jurídico mais singelo: estando descritas no edital, é lícita sua exploração.

A dificuldade do tema surge com relação às receitas secundárias que afloram durante a execução do contrato de concessão. Por vezes o edital e o contrato já trazem cláusulas permissivas genéricas, dando condições de exploração de eventual utilidade adjacente à atividade concedida, sempre visando a modicidade tarifária e desde que se mantenha a equação econômico-financeira estabelecida por ocasião da assinatura do contrato.

Todavia, não são raros os contratos de concessão silentes quanto a estas possíveis intercorrências. Cabe ao particular se apropriar de tal ganho? Quais as diretrizes para a alteração da política remuneratória estabelecida inicialmente?

Para responder a estas questões partiremos de uma premissa: é dever do Poder Concedente, por força do princípio da eficiência e da modicidade tarifária, exigir do concessionário a exploração máxima de todas as potencialidades do serviço a ele concedido, desde que por ele autorizado e sem prejuízos à atividade fim da delegação. Vale 
lembrar também que, muitas vezes, o serviço prestado se faz com o uso de bem público. Neste sentido, cabe à Administração, à luz da função social da propriedade, exigir do particular a exploração de todas as utilidades econômicas deste bem. Esta é a doutrina de Floriano de Azevedo Marques Neto ${ }^{73}$ :

Refutamos, então, o entendimento de que o bem público cumpre sua função social pelo simples fato de ser de domínio do ente de direito público. Nada mais equivocado.

Primeiro, porque para o atendimento pleno da função social do bem há que se perquirir se o emprego específico a ele dado corresponde à melhor utilidade que dele se pode extrair.

(...)

De outro lado, o bem integrante do patrimônio público ao qual não se dá qualquer uso direta ou indiretamente de interesse da coletividade (ou seja, bem desprovido de utilidade pública), não pode ser tido como consentâneo à função social da propriedade pelo simples fato de ser de domínio de ente público.

(...)

Por fim - e talvez mais polêmico - há o fato de que a gestão dos recursos públicos, sempre insuficientes para atender todas as obrigações de que se incumbe o Estado, leva-nos a constatar que a função social dos bens integrantes do patrimônio público só é plenamente atendida se forem aproveitadas todas as utilidades conciliáveis que possam ser suportadas pelo bem.

(grifamos)

Essa premissa, da compulsoriedade da busca pela exploração máxima dos ativos delegados ao particular, nos leva a uma primeira conclusão: é tanto possível quanto indicado que uma utilidade qualquer, aflorada no curso da concessão, deva a ela ser incorporada, desde que não comprometa ou prejudique a atividade fim almejada com a delegação. Cai por terra, portanto, o entendimento daqueles que interpretam o art. 11 da Lei Federal $n^{\circ} .8 .987 / 1995$ em sua literalidade. Consta de referido dispositivo o poder da Administração PREVER, no edital de licitação, a possibilidade de outras fontes de receitas, afora a tarifária, em favor da concessionária. O vocábulo "prever" conduz a uma equivocada conclusão: utilidades extemporâneas ao edital não são legítimas. Não é essa a interpretação mais adequada à realidade concessória brasileira. Vejamos:

Lei Federal no $n^{\circ} 8.666 / 1993$ :

Art. 58. O regime jurídico dos contratos administrativos instituído por esta Lei confere à Administração, em relação a eles, a prerrogativa de:

I - modificá-los, unilateralmente, para melhor adequação às finalidades de interesse público, respeitados os direitos do contratado;

\footnotetext{
${ }^{73}$ MARQUES NETO, Floriano de Azevedo. Bens públicos. Função social e exploração econômica. O regime jurídico das utilidades públicas. Belo Horizonte: Fórum, 2009, pp. 396/397.
} 
É permitido à Administração, portanto, modificar o inicialmente pactuado, visando o interesse público. E atende ao interesse público permitir que novas fontes de receitas sejam incorporadas a uma concessão já em curso, pois visam a modicidade tarifária.

Justificada a possibilidade de incorporação de fontes secundárias de receitas à sistemática remuneratória, cabe analisar quais as diretrizes a serem observadas para sua implementação. Como já tratado no item 4.3., a equação econômico-financeira do contrato de concessão deve ser mantida. Desta forma, a aceitação de nova forma de remuneração deve vir acompanhada de análise do fluxo financeiro da concessão, repartindo-se eventuais ganhos, sempre visando a manutenção do equilíbrio inicialmente pactuado ${ }^{74}$.

Por fim, uma última particularidade acerca da implementação de receitas adicionais durante a execução do contrato de concessão merece análise mais acurada. Alguns doutrinadores entendem que alterações deste jaez estão atreladas aos aspectos econômico-financeiros da concessão e, por força do disposto no $\S 1^{\circ}$ do art. 58 da Lei Federal nº. 8.666/1993, só podem ser incorporadas após a concordância do contratado ${ }^{75}$.

Não nos parece, com a devida vênia, ser o melhor entendimento. Condicionar a possibilidade de implementação de receitas secundárias à concordância do concessionário é o mesmo que deixá-lo livre para dispor sobre política tarifária. Identificada uma utilidade explorável, que resulte em tarifas mais módicas ou até inexistentes (receitas alternativas), é dever da Administração incorporá-las à concessão.

\footnotetext{
74 Parece-nos que uma boa forma de se verificar se uma concessão estará equilibrada após qualquer modificação de suas condições iniciais é analisar, depois de implementadas as alterações, se a Taxa Interna de Retorno (TIR) continua sendo a mesma do momento da contratação.

${ }^{75}$ Fernando Vernalha Guimarães assim se manifestou: "Ainda que se trate a hipótese de instrumento ao alcance de tarifas módicas, cumprindo-se um princípio fundamental do serviço público concedido, não é admissível que tal se faça ignorando direitos do particular (e a força vinculante do contrato). Toda uma já consolidada construção doutrinária acerca das balizas que orientam a tensão entre prerrogativas públicas e direitos dos particulares pode ser lembrada para evidenciar a procedência do raciocínio. Nos últimos tempos, aliás, só se assistiu ao fortalecimento das garantias individuais em face de competências autoritárias do Poder Público, o que se notou especialmente no terreno da contratação administrativa". (GUIMARÃES, Fernando Vernalha. As receitas alternativas nas concessões de serviços públicos no direito brasileiro. In: Revista de direito público da economia. Belo Horizonte: Fórum, vol. 6, nº. 21, janeiro 2008).
} 
Trata-se de questão ligada à política tarifária e, portanto, unilateralmente disponível pelo Poder Público.

\subsection{O IMPACTO SOCIAL}

A percepção de receitas secundárias deve também trazer, além de ganhos financeiros à estrutura econômica da concessão, positividades sociais que justifiquem sua implementação. Como fizemos constar anteriormente, é pressuposto de sua permissividade a obtenção de eficiências traduzidas, em linhas gerais, à modicidade tarifária. Contudo, não se resume apenas a este aspecto, como adiante restará demonstrado.

Por vezes a implementação de atividade capaz de gerar receita secundária irá prejudicar a atividade principal. Apesar de, em regra, permitir a diminuição do valor da tarifa, o consequente prejuízo ao objeto central da concessão é suficiente para impedir seja a mesma colocada em prática.

Em outras situações pode a tarifa permanecer a mesma, mas haver ganhos de qualidade, não só especificamente à atividade delegada, mas com o oferecimento de utilidades outras de interesse coletivo. Nestes casos, apesar do postulado da modicidade tarifária não ter sido atingido de imediato, os ganhos de qualidade e de oportunidade acabam por induzir a este resultado.

Isto tudo para demonstrar que a busca pela eficiência nem sempre está pautada pela lógica econômica. Também digno de nota não ser sempre necessária a diminuição da tarifa, para se ter por atendido o postulado da modicidade tarifária. A inclusão de fonte secundária de receitas culmina, portanto, com alterações factuais que 
devem, obrigatoriamente, impactar positivamente a atividade como um todo, majorando a satisfação dos usuários do serviço concedido.

Tais ganhos sociais nos parecem ser os verdadeiros permissivos para a implementação de receitas desta natureza. Em certas ocasiões as novas atividades incorporadas à concessão proporcionam ganhos a terceiros, não usuários do serviço principal. Nestes casos o impacto social é ainda mais evidente, pois beneficia toda a sociedade, e não apenas a parcela usuária do serviço. Vale lembrar, todavia, que apesar de possível e desejável, não é imprescindível à implementação de receita secundária a existência de externalidades positivas fruíveis por todos.

Enfim, nos parece imprescindível que impactos sociais positivos decorram da implementação de receita secundária nos contratos de concessão.

\subsection{POSSIBILIDADE DE REMUNERAÇÃO DO PARTICULAR EXCLUSIVAMENTE POR ESTE MEIO}

$\mathrm{Na}$ maioria das vezes a receita secundária servirá como uma complementação à receita principal - tarifa. Todavia, pretendemos tratar neste item da possibilidade da receita secundária se tornar a principal, ou seja, superá-la em montante arrecadatório, podendo chegar inclusive a ser a única forma de remuneração do concessionário.

Rafael Wallbach Schwind ${ }^{76}$, em valorosa obra sobre remuneração do concessionário (fruto de sua dissertação de mestrado), trata da natureza jurídica dos empreendimentos geradores de receitas marginais, afirmando serem atividades econômicas

${ }^{76}$ Op. Cit., p. 278. 
em sentido estrito. Afirma, outrossim, que "o fato de a atividade econômica gerar receitas marginais para o custeio da prestação de um serviço delegado não a transforma em um serviço público". Diferencia o ilustre jurista a atividade principal como de natureza pública, enquanto de natureza jurídica privada a secundária.

Com a devida vênia, este raciocínio não nos parece estar totalmente correto. É válido em boa parte dos casos, onde a atividade da qual se obtém a receita secundária apresenta-se como típica atividade econômica. Todavia, consideramos viável que se execute atividade paralela à principal, gerando receita secundária - a qual, entretanto, é possível ser classificável como serviço público tendo, portanto, a mesma natureza da atividade principal (pública). A título de exemplo, podemos imaginar a concessão da ampliação, manutenção e exploração de um aeroporto em que fica também permitido o transporte de passageiros entre seus longínquos estacionamentos e os setores de embarque/desembarque, mediante paga.

Feita esta ponderação, há de se distinguir dois cenários em que a remuneração do particular poderá advir totalmente de fonte secundária de receita. $\mathrm{O}$ primeiro refere-se às hipóteses onde o agente privado irá explorar atividade econômica paralela ao objeto da delegação. Neste caso haverá ampla liberdade do concessionário acerca de questões estratégicas envolvidas na atividade secundária, cabendo ao Poder Concedente fiscalizar a execução da atividade principal, mas não regular o exercício da externalidade típica de mercado utilizada como fonte primordial de receita. Caberá ao particular estabelecer os preços dessa atividade, limitado apenas às normas concorrenciais. Não poderá a Administração ditar as regras dessa operação. Desse cenário pode-se antever uma considerável instabilidade da equação econômico-financeira, pois apresentará a concessão dinâmica econômica bastante intensa. Qualquer alteração da sistemática específica de prestação dessa atividade implicará em respostas rápidas desse mercado consumidor e, por conseguinte, impactos imediatos no fluxo de caixa da operação. 
Diferentemente se dá nos casos em que a atividade secundária é um serviço público. Por força dos seus princípios diretores, sua política exploratória não dá azo à ampla liberdade de atuação do agente privado. Deverá se pautar por questões atinentes ao serviço prestado, mesmo quando contrárias à regra de mercado: modicidade da tarifa, continuidade, atualidade, dentre outras. Sua flexibilidade de atuação é sensivelmente menor. O Poder Concedente deverá acompanhar as estratégias da atuação privada, atentando aos preceitos que regem os serviços públicos.

Em qualquer dos casos, todavia, é possível se remunerar o particular exclusivamente das receitas oriundas de fontes secundárias que, neste caso, passarão a ser as fontes primordiais de recursos na concessão.

\subsection{FLEXIBILIDADE E REEQUILÍBRIO CONTRATUAL}

Percebe-se, portanto, que substanciais recursos podem advir de "receitas secundárias". Porém, só podem ser implementadas num regime de flexibilidade contratual, ou seja, em contextos contratuais que autorizem alterações em parcela significativa de seu conteúdo - a remuneração do prestador do serviço.

Tais cláusulas compõem o núcleo econômico do contrato e, por isso, integram sua parcela disponível. Não cabe aqui discorrer sobre a disponibilidade do interesse público, pois já é pacífica na doutrina mais moderna a legalidade da consensualidade nos contratos administrativos. Certamente esta faculdade encontrará seus limites no modal delegatório do serviço público em si. Mas não impede sejam implementadas alterações não atinentes a este particular. 
Em outras palavras, tanto viável quanto salutar que os contratos administrativos, em especial os contratos de concessão/permissão de serviços públicos, aceitem alterações em suas esferas econômico-financeiras, balizadas pelos seus princípios norteadores, mas sem perder de vista seu real objetivo: o de permitir a consecução do interesse público em sua totalidade.

Num regime de flexibilidade contratual, portanto, pode-se cogitar da utilização de fontes secundárias de receitas para o fim de reequilibrar contratos desequilibrados. Talvez alguns encontrem resistência em admitir tal sugestão ao cotejá-la com o disposto no art. 11 da Lei Federal $n^{\circ}$. 8.987/1995. Isso porque, da leitura literal desse dispositivo, pode-se concluir só ser possível a inserção de outras fontes de receitas à concessão para o fim de favorecimento da modicidade tarifária. Nesta esteira, ao se permitir a assunção, pelo particular, de nova fonte de receitas para o fim de reequilibrar o contrato de concessão, não teríamos atendido o comando que determina como objetivo a modicidade tarifária, pois não haveria redução do valor da tarifa.

Vale lembrar, todavia, que apesar de não haver minoração tarifária também não haverá sua majoração. Uma das formas de se reequilibrar a concessão é através do aumento da tarifa. Ao se evitar o aumento, nos parece razoável concluir estar atendido o objetivo de favorecimento da modicidade tarifária.

Desta forma, temos como viável, por vezes até desejável, a extração de fontes secundárias de receitas como forma de recomposição contratual. Convém destacar, outrossim, que os ganhos derivados dessas fontes alternativas, caso superem os patamares estritamente necessários ao reequilíbrio, devem ser partilhados entre Poder Concedente e Concessionário.

Com efeito, não é certo ficar para o concessionário todo o ganho oriundo da implementação de novas atividades geradoras de receitas secundárias. De outra feita, não é lógico que esse ganho, para além do necessário à recomposição contratual, seja 
integralmente repassado ao Poder Concedente. Isso porque não haveria motivação alguma de exploração dessa novel atividade, em sua máxima potencialidade, caso o concessionário não vislumbrasse, ao final, um aumento em seus ganhos, mesmo se suplantada a estimativa inicial estampada em sua proposta comercial. Vale lembrar que tal raciocínio se aplica não só nos casos de implementação de fontes secundárias de receitas para fins de reequilíbrio econômico-financeiro do contrato, mas de forma geral nas concessões. 


\section{O CASO DAS PARCERIAS PÚBLICO-PRIVADAS}

7.1. Regime misto e invertido de remuneração:

7.1.1. A contraprestação pública; 7.2.

Remuneração exclusivamente pública: 7.2.1.

Natureza jurídica e suas consequências; 7.3.

Possibilidade de recebimento de recursos antes da disponibilização do serviço: 7.3.1. Subsídio; 7.3.2. Subvenção.

Baseado em experiências estrangeiras de sucesso e impulsionado por legislações estaduais sobre o tema, o legislador federal brasileiro editou, no fim de 2004, a Lei Federal n ${ }^{\circ}$. 11.079, instituindo normas gerais para licitação e contratação de parceria público-privada no âmbito da administração pública. 
Aludida legislação tornou possível novos modelos concessórios, permitindo a delegação de atividades não autossustentáveis, ou seja, cujas receitas de sua exploração não sejam suficientes para a remuneração completa de seu executor.

Duas novas formas de se conceber um projeto foram criadas pela lei, que acabou por transformar o instituto da concessão em gênero, tendo por espécies: i) concessão comum; ii) concessão patrocinada e; iii) concessão administrativa.

Está disposto no $\S 3^{\circ}$ do art. $2^{\circ}$ da Lei Federal $n^{\circ}$. 11.079/2004 não constituir parceria público-privada a concessão comum, assim entendida a concessão de serviços públicos ou de obras públicas de que trata a Lei Federal nº 8.987 , de 13 de fevereiro de 1995, quando não envolver contraprestação pecuniária do parceiro público ao parceiro privado. Assim, por força do disposto no $\S 4^{\circ}$ do art. $2^{\circ}$ da Lei das PPPs, continuou válida a sistemática concessória da Lei Federal $\mathrm{n}^{\circ}$. 8.987/1995, especialmente para projetos autossustentáveis, para contratos de valor inferior a $\mathrm{R} \$ 20.000 .000,00$ (vinte milhões de reais), ou com prazo inferior a 5 (cinco) anos.

À concessão patrocinada ficaram os projetos nos quais a remuneração do particular executor da atividade advém não só das tarifas, mas também de contraprestação pecuniária do parceiro público $\left(\S 1^{\circ}\right.$ do art. $2^{\circ}$ da Lei Federal $n^{\circ}$. 11.079/2004). Por fim, à concessão administrativa couberam atividades custeadas exclusivamente pelo parceiro público. A doutrina mais abalizada sobre o tema, encabeçada por Carlos Ari Sundfeld, acabou por dividir a concessão administrativa em duas subespécies: i) concessão administrativa de serviços públicos e; $i$ ) concessão administrativa de serviços ao Estado.

$\mathrm{Na}$ concessão administrativa de serviços públicos uma atividade será delegada à execução por particular, que irá disponibilizá-la gratuitamente aos usuários, cobrando do parceiro público pelo efetivo uso do serviço. Já na concessão administrativa de serviços ao Estado é a Administração quem usufrui da atividade prestada pelo particular, pagando por isso. 


\subsection{REGIME MISTO E INVERTIDO DE REMUNERAÇÃO}

As inéditas espécies de concessões trouxeram consigo novas formas de remuneração. Na sistemática da Lei Federal nº. 8.987/1995 as concessões eram, em regra, idealizadas de forma a permitir que as utilidades inerentes à própria atividade fossem suficientes para permitir exploração econômica capaz de remunerar o particular.

Mas isso nem sempre era possível. Com o advento da Lei das PPPs passou então a Administração a vislumbrar possibilidades de delegação de atividades cujas receitas derivadas diretamente do negócio não fariam frente aos custos de implementação e operação do serviço. A contraprestação do parceiro público complementaria as receitas do particular, garantindo ao mesmo a certeza de um mínimo remuneratório.

A definição legal de concessão patrocinada traz a obrigação de contraprestação PECUNIÁRIA; já na concessão administrativa inexiste tal imposição ${ }^{77}$.

Nas concessões patrocinadas existirá um regime remuneratório misto, pois parte dos recursos serão obtidos através da cobrança de tarifa dos usuários, complementada pela contraprestação estatal. Já nas concessões administrativas os recursos advirão de outras fontes, exceto da exploração da atividade pelo parceiro privado. Inverte-se a lógica concessória, atribuindo cem por cento do ônus econômico da delegação à Administração.

\footnotetext{
${ }^{77}$ Lei Federal n'. 11.079/2004:

Art. $2^{\circ}$ Parceria público-privada é o contrato administrativo de concessão, na modalidade patrocinada ou administrativa.

$\S 1^{\circ}$ Concessão patrocinada é a concessão de serviços públicos ou de obras públicas de que trata a Lei 8.987, de 13 de fevereiro de 1995, quando envolver, adicionalmente à tarifa cobrada dos usuários contraprestação pecuniária do parceiro público ao parceiro privado.

$\S 2^{\circ}$ Concessão administrativa é o contrato de prestação de serviços de que a Administração Pública seja a usuária direta ou indireta, ainda que envolva execução de obra ou fornecimento e instalação de bens.
} 


\subsubsection{A contraprestação pública}

As formas de pagamento da contraprestação que a Administração poderá oferecer nos contratos de PPP estão previstas no art. $6^{\circ}$ da Lei Federal no ${ }^{\circ}$ 11.079/2004 e são: ordem bancária, cessão de créditos não-tributários, outorga de direitos em face da Administração Pública, outorga de direitos sobre bens públicos dominicais, dentre outros meios admitidos em lei. Em qualquer das modalidades a Administração estará comprometendo recursos de seu caixa, ou seja, em tese oriundos de todos os contribuintes, e direcionando para parcela deles (quem usufruirá da atividade).

Seguindo este raciocínio é possível afirmar que a Administração, ao modelar projeto de PPP, está implementando política pública com maior intensidade do que quando delega atividade sob a modalidade de concessão comum.

Mas ao custear, parcialmente ou totalmente, a atividade delegada, está o Estado remunerando o particular a que título? Do ponto de vista econômico tais repasses podem ser considerados subsídios. Vale lembrar não existir o conceito de subsídio na contabilidade pública. Teria então o legislador da lei das PPPs duas opções de enquadramento deste "subsídio": como subvenção (conforme previsão do art. 12 da Lei Federal $\left.n^{\circ} .4 .320 / 1964\right)$ ou como pagamento por serviços prestados pelo parceiro privado. Sobre a natureza da contraprestação vale a transcrição das lições de Mauricio Portugal Ribeiro e Lucas Navarro Prado ${ }^{78}$ :

Ao utilizar o termo "contraprestação", o legislador escolheu, claramente, caracterizar os pagamentos da Administração em PPP como contrapartida à aquisição de serviços. (...)

\footnotetext{
${ }^{78}$ RIBEIRO, Mauricio Portugal; PRADO, Lucas Navarro. Comentários à lei de PPP: parceria públicoprivada - fundamentos econômico-jurídicos. São Paulo: Malheiros, 2007, p. 183.
} 
(...) Fossem os pagamentos das PPPs caracterizados como subvenção econômica, e se poderia entender necessária a prévia autorização do Poder Legislativo para realizar projetos de PPP, à parte as autorizações já previstas no art. 175 da CF, na lei de PPP e/ou nas Leis 8.987/1995 e 9.074/1995.

(...)

Também por essa razão, o art. 19 da Lei 4.320/1964 exige autorização expressa por lei especial para a realização de subvenções para empresas com fins lucrativos. E foi esse o problema fundamental que impediu a caracterização dos pagamentos públicos em PPPs como subvenções.

(sem ênfase no original)

Seja qual for a modalidade de contraprestação a ser oferecida pela Administração, deve estar claramente prevista no edital, dando chance ao particular de analisar minuciosamente o desenho financeiro da parceria proposta.

Por fim, antes de analisarmos especificamente cada uma das possibilidades, de rigor notar que a lei deixa aberto ao administrador idealizar outras formas de contraprestação, de acordo com a engenharia econômica e com as potenciais utilidades do projeto a ser concedido.

\section{a) ORDEM BANCÁRIA}

É a transferência bancária de numerário da conta da Administração para a conta do parceiro privado. É a modalidade de contraprestação de maior liquidez.

\section{b) CESSÃO DE CRÉDITOS NÃO-TRIBUTÁRIOS}

Prevista nos artigos 286 a 298 do Código Civil, nada mais é do que um contrato onde a Administração se compromete a transferir recebíveis ao parceiro privado. Esses recebíveis não podem ter origem tributária. A título de exemplo, é possível conceber PPP na qual a contraprestação do parceiro público se dará com a cessão dos valores que este recebe a título de outorga de uma concessão comum.

c) OUTORGA DE DIREITOS EM FACE DA ADMINISTRAÇÃO 
A contraprestação é um direito a ser outorgado pela Administração. Apesar de abarcar uma infinidade de possibilidades, permite desenhos financeiros não usuais e sofisticados. Cada ente público poderá oferecer soluções diferentes, adequando a gama de direitos de que dispõe à realidade do projeto. Cada um desses direitos deverá obedecer, na sua outorga, eventuais requisitos legais (autorização legislativa, por exemplo).

\section{d) OUTORGA DE DIREITOS SOBRE BENS PÚBLICOS DOMINICAIS}

É o comprometimento de patrimônio público não afetado através do oferecimento de direitos pessoais ou reais que sobre eles recaiam.

Essas formas de contraprestação, dentre outras, comporão a remuneração do parceiro privado.

\subsection{REMUNERAÇÃO EXCLUSIVAMENTE PÚBLICA}

Tratamos acima das espécies de contraprestações disponíveis pela Administração ao modelar uma PPP. Nas concessões patrocinadas a contraprestação alcançará qualquer percentual remuneratório ${ }^{79}$, menos sua totalidade ${ }^{80}$. Já nas concessões

\footnotetext{
${ }^{79}$ Lei Federal no $.11 .079 / 2004$ :

Art. 10 .

(...)

$\S 3^{\circ}$ As concessões patrocinadas em que mais de $70 \%$ (setenta por cento) da remuneração do parceiro privado for paga pela Administração Pública dependerão de autorização legislativa específica.

${ }^{80}$ Alguns doutrinadores entendem possíveis as denominadas concessões TOTALMENTE patrocinadas. Para Mario Engler Pinto Junior “a concessão totalmente patrocinada não se confunde com a concessão administrativa, embora ambas dispensem a arrecadação tarifária. $\mathrm{O}$ elemento diferenciador reside na natureza do serviço concedido. No primeiro caso, trata-se de serviço potencialmente tarifável sob o ponto de vista técnico e jurídico, embora não efetivamente tarifado por mera opção política. No segundo caso, o serviço concedido não comporta absolutamente a tarifação, pois ou se destina ao uso e consumo da própria Administração (usuária direta) ou se reveste de caráter uti universi, por beneficiar um conjunto difuso ou indeterminado de pessoas (usuária indireta).” (PINTO JUNIOR, Mário Engler. Parceria público-privada:
} 
administrativas o que teremos é exatamente o oposto: 100\% (cem por cento) da remuneração do parceiro privado advirá de contraprestação do parceiro público.

Tal característica, dentre outras, levou alguns doutrinadores a chamarem a concessão administrativa de "falsa concessão". Vejamos as lições de Antônio Carlos Cintra do Amaral $^{81}$ :

\begin{abstract}
A nova lei criou um segundo tipo de PPP. É a chamada "concessão administrativa", que de concessão não tem nada. Trata-se de prestação de serviços à Administração Pública, que extrapola o prazo-limite de 60 meses, prorrogáveis excepcionalmente por até 12, estabelecido no art. 57, inciso II e $\S 4^{\circ}$, da Lei 8.666/93. A adoção dessa impropriamente denominada concessão exige o atendimento de quase os mesmos requisitos exigidos para a "concessão patrocinada". Algumas características específicas: assim como na "concessão patrocinada", o prazo deve ser igual ou superior a cinco anos, mas a prestação do serviço pode ser contratada por prazo inferior, só que nessa hipótese o contrato é regido exclusivamente pela Lei 8.666/93 e não toma o nome de "concessão administrativa"; a contraprestação paga pela Administração Pública é de $100 \%$, o que torna a situação curiosa, porque a adoção de "concessão patrocinada" em que a contraprestação do poder concedente seja, por exemplo, de $75 \%$, exige autorização legislativa específica, enquanto a chamada "concessão administrativa", que pressupõe a contraprestação de $100 \%$ pela Administração, dispensa esse requisito; a prestação efetiva do serviço tanto pode ser efetuada diretamente à Administração Pública contratante, quanto a usuários pessoas privadas, embora estes não integrem a relação jurídico-contratual. ${ }^{82}$
\end{abstract}

Não é esse entendimento, entretanto, o que melhor explica a sistemática proposta pela Lei Federal n ${ }^{\circ}$. 11.079/2004. Ao conceber uma concessão administrativa está a Administração visando um investimento elevado, que demandará um lapso maior para possibilitar a amortização dos investimentos. Investimento e prazo mínimo acabam por impor um regime contratual bastante diverso do regime das simples contratações de prestação de serviços. Ademais, a concessão administrativa atribui parcela de risco ao

antigas e novas modalidades contratuais. In: PAVANI, Sérgio Augusto Zampol; ANDRADE, Rogério Emilio (Coords.). Parcerias público-privadas. São Paulo: MP, 2006, p. 81). Nesta mesma linha seguem Claudia Elena Bonelli e Rodnei Iazzetta (BONELLI, Claudia Elena; IAZZETTA, Rodnei. Contratos de parceria público privada: PPP no Brasil. In: CASTRO, José Augusto Dias; TIMM, Luciano Benetti (Orgs.). Estudos sobre as parcerias público-privadas. São Paulo: IOB Thomson, 2006, p. 98). Não obstante as importantes contribuições dos autores acima citados, nos parece ser impossível uma concessão totalmente patrocinada. A lei, ao conceituar a concessão patrocinada (art. $2^{\circ}, \S 1^{\circ}$ ), estabeleceu que eventual contraprestação pecuniária do parceiro público ao parceiro privado será ADICIONAL à tarifa cobrada do usuário. Essa ideia de adição dá a entender que não poderá deixar de existir tarifa a ser cobrada do usuário, mesmo sendo ínfima.

81 AMARAL, Antônio Carlos Cintra do. Concessão de serviços públicos: novas tendências. São Paulo: Quartier Latin, 2012, p. 40.

${ }^{82}$ No mesmo sentido: MELlo, Celso Antônio Bandeira de. Curso de direito administrativo. 21. Ed. São Paulo: Malheiros, 2006, p. 739; FERREIRA, Luiz Tarcísio Teixeira. Parcerias público-privadas, aspectos constitucionais. Belo Horizonte: Fórum, 2006, pp. 73/74. 
parceiro privado, algo inexistente nas singelas prestações de serviços. Tratando do tema, Vera Monteiro $^{83}$ extirpa a discussão:

\begin{abstract}
Com o olhar na legislação, a concessão administrativa da Lei 11.079/2004 diferencia-se do contrato típico de prestação de serviços da Lei 8.666/1993 porque nela (1) o concessionário deve promover investimento em valor superior a $\mathrm{R} \$ 20.000 .000,00$ (art. $2^{\circ}, \S 4^{\circ}, \mathrm{I}$ ); (2) a contraprestação é paga pelo poder concedente, sempre a partir da disponibilização do serviço contratado (art. $7^{\circ}$ ); (3) o prazo do contrato deve estar inserido no intervalo entre 5 e 35 anos (art. $2^{\circ}, \S 4^{\circ}$, II, e art. $5^{\circ}$, I); e (4) o objeto da prestação não pode se restringir à execução isolada de obra ou ao fornecimento isolado de mão-de-obra ou bens, devendo estar diretamente associado ao serviço objeto da concessão administrativa, o qual, não pode negar, é o mesmo do art. $6^{\circ}$ da Lei 8.666/1993 (art. $2^{\circ}$, $\S 4^{\circ}$, III).

E o modelo básico contratual da Lei 8.666/1993 não se confunde com a concessão administrativa da Lei 11.079/2004 porque naquele modelo a Administração responsável pelo serviço só formaliza a contratação se tiver previsão de recursos orçamentários próprios para levá-lo até o final; o contratado recebe sua remuneração durante a prestação do serviço, segundo medições que determinem qual o dispêndio do contratado no período, observado o prazo máximo de pagamento de 30 dias para cada parcela, sob pena de incidirem encargos de mora; e não é permitida a vinculação do pagamento pela prestação do serviço à exploração que se venha a fazer do empreendimento.
\end{abstract}

Infere-se do trecho acima transcrito ser a diferença do sistema remuneratório um dos elementos que tornam a concessão administrativa não uma "falsa concessão", mas sim uma espécie do gênero concessão, pois compõe um ambiente contratual de cooperação entre público e privado (horizontalidade das relações), e não de singelo cumpridor do pactuado (verticalidade).

Mas a remuneração na concessão administrativa levantou também outras discussões. Alguns doutrinadores defendem que na concessão de serviços públicos, por força do disposto no art. 175 da Constituição Federal (referente à política tarifária), a remuneração do concessionário se dá basicamente pela tarifa cobrada do usuário ou por receitas alternativas, sempre atreladas à própria atividade concedida. Encabeça esse grupo Celso Antônio Bandeira de Mello ${ }^{84}$, seguido pela Profa. Maria Sylvia Zanella Di Pietro ${ }^{85}$.

\footnotetext{
${ }^{83}$ Op. Cit., p. 178

${ }^{84}$ Op. Cit., p. 703

${ }^{85}$ Op. Cit., p. 165.
} 
Luiz Tarcísio Teixeira Ferreira ${ }^{86}$, em estudo específico sobre a constitucionalidade das parcerias público-privadas, alinhando-se com o entendimento de que o comando constitucional em apreço estabelece um conteúdo semântico mínimo (conduzindo-nos à ideia de remuneração exclusivamente por tarifas, bem como por receitas outras derivadas da exploração empresarial do serviço, nas concessões de qualquer espécie), conclui:

Seria, pois, inconstitucional a concessão administrativa, porque estaria a esconder, sob esse nome, verdadeiro contrato de prestação de serviço, com remuneração integral do parceiro público, a título de contraprestação, ou de "tarifa zero".

Gustavo Binenbojm ${ }^{87}$, considerando se referir o inciso III do art. 175 da Carta da República a "política tarifária", mas não a "tarifa", defende não haver necessidade de que a remuneração nas concessões advenha exclusivamente da tarifa cobrada dos usuários. Na mesma esteira o magistério de Benedicto Porto Neto ${ }^{88}$.

Alexandre Santos de Aragão ${ }^{89}$ é mais contundente, dando entendimento diverso ao comando constitucional, concluindo sequer existir tarifa nas concessões administrativas:

\begin{abstract}
Subsistem, contudo, em setor da doutrina, mesmo após a Lei $\mathrm{n}^{\circ}$. 11.079/04, dúvidas constitucionais quanto à admissibilidade de concessões total ou parcialmente subsidiadas pelo Estado, já que interpretam o art. 175 da Constituição Federal como admitindo apenas as concessões que sejam remuneradas integralmente por tarifas pagas pelos usuários por conta e risco do concessionário, o que seria inferido inclusive da determinação de que a concessão deve ter uma "política tarifária" (art. 175, parágrafo único, III, CF).

A nosso ver, a mera referência à "política tarifária" não pode levar a tão longe. (...)

Não é possível admitir que o Constituinte tenha engessado de tal maneira o Legislador, a ponto de colocá-lo sempre atado a uma definição doutrinária tradicional de concessão, indiferente a todas as enormes mudanças sociais, econômicas e políticas verificadas após 05 de outubro de
\end{abstract}

${ }^{86}$ Op. Cit., p. 74.

${ }^{87}$ BINENBOJM, Gustavo. As parcerias público-privadas (PPPs) e a constituição. In: Revista eletrônica de direito administrativo econômico. Salvador, Instituto de Direito Público da Bahia, n. 2, maio-jun.-jul., 2005. Disponível na internet: <http://www.direitodoestado.com.br>. Acesso em 03 abril 2013.

${ }^{88}$ PORTO NETO, Benedicto. Licitação para contratação de parceria público-privada. In: SUNDFELD, Carlos Ari (Coord.). Parcerias público-privadas. São Paulo: Malheiros, 2005, p. 143.

${ }^{89}$ ARAG ÃO, Alexandre Santos de. As parcerias público-privadas - PPP's no direito positivo brasileiro. In: Revista eletrônica de direito administrativo econômico. Salvador, Instituto de Direito Público da Bahia, n. 2 , maio-jun.-jul., 2005. Disponível em: <http://www.direitodoestado.com.br>. Acesso em 08 abril 2013. 
1988. Ademais, "política tarifária" pode perfeitamente ser entendida como a política segundo a qual a tarifa deve cobrir apenas parte do custo do serviço público, sendo o restante arcado pelo Estado.

(...)

As chamadas pela Lei $\mathrm{n}^{\circ} .11 .079 / 04$ de "concessões administrativas" são contratos em que a cobrança de tarifas é inviável econômica ou socialmente...

Aqui não se fala mais sequer em tarifa a ser complementada por verbas do Estado, mas da inexistência tout court de tarifas.

Por fim, vale a transcrição das lições de Floriano de Azevedo Marques Neto ${ }^{90}$ sobre o tema:

Portanto, não vejo como sustentar ser à lei vedado estipular modalidade de concessões alternativas àquela típica, disciplinada pela Lei nº 8.987/95. A própria Constituição (artigo 175, Parágrafo único, III) ao aludir a remuneração nos serviços públicos delegados faz menção não a tarifas e sim à política tarifária a ser definida por lei, o que a meu ver autoriza inclusive que o legislador defina serviços públicos que sejam objeto de concessão com uma política de subsídios públicos intensa (até mesmo se cogitando de serviços públicos com tarifa zero, como alhures chegou-se a defender).

Para nós, não decorre do artigo 175, Parágrafo único, inciso III da Constituição Federal a conclusão de que nas concessões de serviços públicos a remuneração pela atividade prestada pelo concessionário deva advir essencialmente das tarifas cobradas dos usuários. Referindo-se à política tarifária (e não especificamente à tarifa) está o legislador constitucional atribuindo um sistema remuneratório às concessões, contudo não atrelando os recebíveis do executor do serviço às utilidades extraíveis da própria concessão. Desta forma, assiste razão à parcela da doutrina que dá à expressão "política tarifária" um sentido mais amplo, possibilitando a remuneração exclusivamente por recursos do orçamento (ou seja, não oriundas de tarifas e de utilidades econômicas atreladas à própria atividade).

\subsubsection{Natureza jurídica e suas consequências}

\footnotetext{
${ }^{90}$ MARQUES NETO, Floriano de Azevedo. As parcerias público-privadas no saneamento ambiental. In: Revista eletrônica de direito administrativo econômico. Salvador, Instituto de Direito Público da Bahia. n. 2, maio-jun.-jul., 2005. Disponível em: 〈http://www.direitodoestado.com.br>. Acesso em 08 abril 2013.
} 
Como apontado alhures a contraprestação do parceiro público ao parceiro privado nada mais é do que um pagamento público devido por força do desempenho de atividade e/ou serviço executado. Sua natureza jurídica acaba por impor diferenças operacionais, quando comparado aos subsídios estatais e subvenções.

E qual motivo nos leva a concluir serem as contraprestações do parceiro público pagamentos, e não subsídios/subvenções? Da leitura do caput do art. $7^{\circ}$ da Lei Federal $\mathrm{n}^{\circ}$. 11.079/2004 nota-se só fazer jus o parceiro privado a tais valores quando efetivamente executar alguma atividade; ou seja, há equivalência entre disponibilização do serviço objeto da delegação e recebimento da contraprestação (o que não ocorre nos casos onde a Administração oferece subsídios).

Ademais, não foi sem razão que o legislador assim o fez. Ao "fugir" da subvenção, atribuiu uma série de consequências à operacionalização dessas contraprestações. A primeira é a desnecessidade de edição de lei específica para cada projeto de parceria. Nos termos do art. 19 da Lei Federal no $.4 .320 / 1964^{91}$, a subvenção só é possível após expressamente autorizada em lei especial. Nesta esteira, seria necessária, para cada contrato de PPP, uma lei especial autorizando o pagamento a esse título.

Uma segunda consequência desse correto enquadramento da contraprestação diz respeito à possibilidade do seu oferecimento no setor da saúde. $\mathrm{O} \S 2^{\circ}$ do art. 199 da Constituição Federal dispõe ser vedada a destinação de recursos públicos para auxílios ou subvenções às instituições privadas de assistência à saúde com fins lucrativos.

Por fim, uma terceira consequência é a incidência de tributos, não aplicável às subvenções.

${ }^{91}$ Lei Federal no . 4.320/1964:

Art. 19. A Lei de Orçamento não consignará ajuda financeira, a qualquer título, a empresa de fins lucrativos, salvo quando se tratar de subvenções cuja concessão tenha sido expressamente autorizada em lei especial. 


\subsection{POSSIBILIDADE DE RECEBIMENTO DE RECURSOS ANTES DA DISPONIBILIZAÇÃO DO SERVIÇO}

A redação original da Lei Federal $n^{\circ} .11 .079 / 2004$ impedia o pagamento da contraprestação da Administração Pública ao parceiro privado sem que este previamente disponibilizasse o serviço objeto do contrato de PPP (caput do art. $7^{\circ}$ ). Era permitido, à luz do antigo Parágrafo único do mesmo artigo, apenas o pagamento das contraprestações relativas às parcelas fruíveis da atividade delegada, o que já melhorava, mas não resolvia alguns problemas de eficiência econômica dos projetos, como adiante restará demonstrado.

Sobre a impossibilidade de antecipação da contraprestação, ainda na vigência da redação original da lei, Mauricio Portugal Ribeiro e Lucas Navarro Prado ${ }^{92}$ assim consignaram:

Do ponto de vista estritamente técnico, contudo, sua redação revela opção por um modelo de PPP em detrimento de outros. Ao exigir que a contraprestação só se faça após a disponibilidade dos serviços, a Lei de PPP afastou a possibilidade de se fazer projetos de PPPs que prevejam subsídio ao investimento na infra-estrutura.

Aos 7 de agosto de 2012 a Presidente da República, no uso da atribuição a ela conferida pelo art. 62 da Constituição, fez editar a Medida Provisória nº. 575, alterando a Lei Federal nº 11.079/2004. Da exposição de motivos da referida medida constou:

Submetemos à apreciação de Vossa Excelência projeto de Medida Provisória que altera a Lei $\mathrm{n}^{\circ}$. 11.079, de 30 de dezembro de 2004, que disciplina os contratos de Parceria Público-Privada - PPP, visando disciplinar o tratamento tributário do aporte de recurso a uma Sociedade de Propósito Específico - SPE em contrato de PPP, aprimora aspectos relativos ao Fundo Garantidor de Parcerias Público-Privadas - FGP e aumenta o limite de comprometimento com

${ }^{92}$ Op. Cit., p. 195. 
despesas de caráter continuado derivadas do conjunto das PPP.

2. A primeira alteração permite o tratamento tributário do aporte de recurso a uma Sociedade de Propósito Específico - SPE em contrato de PPP por intermédio de diferimento tributário, tendo em vista a impossibilidade contábil do confronto do recebimento dos aportes (receitas) com a respectiva realização dos custos do contrato, a exemplo da despesa com depreciação do bem cujo custo foi reconhecido no ativo da SPE. Para tanto, propõe-se a alteração do art. $6^{\circ}$ da Lei $\mathrm{n}^{\circ}$. 11.079, de 2004, transformando o seu parágrafo único em $\S 1^{\circ}$ e acrescentando-lhe os $\S \S 2^{\circ}, 3^{\circ}$ e $4^{\circ}$.

3. A inclusão do $\S 2^{\circ}$ possibilita que o contrato preveja o aporte de recursos para o parceiro privado, autorizado por lei específica, para a construção ou aquisição de bens reversíveis, nos termos dos incisos X e XI, do art. 18 da Lei no. 8.987, de 13 de fevereiro de 1995.

A Medida Provisória foi convertida na Lei Federal $n^{\circ}$. 12.766, de 27 de dezembro de 2012. Assim, significativas alterações foram incorporadas às PPPs, dentre elas a possibilidade do parceiro público efetuar aporte de recursos em favor do parceiro privado para a realização de obras e aquisição de bens reversíveis. Percebe-se (inclusive do trecho da exposição de motivos acima transcrito) que buscou a MP possibilitar arranjos econômicos mais eficientes, diminuindo o custo de capital para construção e/ou aquisição da infraestrutura e dos bens necessários à prestação da atividade concedida.

A Lei Federal n ${ }^{\circ} .12 .766 / 2012$, afora outros aspectos, criou a possibilidade de pagamentos ao parceiro privado. Estes não se confundem com a contraprestação, pois os "aportes" visam possibilitar a construção de infraestrutura, enquanto a contraprestação está atrelada à remuneração da prestação da atividade concedida.

A novel redação da Lei de PPPs trouxe uma forma de obtenção de recursos do Poder Concedente que tornou as parcerias muito mais atraentes. Ao ser questionado pela reportagem do sítio eletrônico Migalhas a respeito do assunto, Floriano de Azevedo Marques Neto ${ }^{93}$ assim se manifestou:

(...) o aporte, tal qual instituído pela lei, diminui sensivelmente o custo financeiro e o custo tributário das PPPs. No primeiro caso, ao permitir a disponibilização do aporte concomitante à realização dos investimentos, evita-se o encargo outrora previsto pelo art. $\mathbf{7}^{\mathbf{0}}$, advindo da vedação ao pagamento da contraprestação enquanto não disponibilizado os serviços. Na prática, essa vedação forçava o parceiro privado a realizar todos os

\footnotetext{
${ }^{93}$ Disponível em: <http://www.direitopublico.com.br/noticias2.php?id=1835>. Acesso em 09 abril 2013.
} 
investimentos sem ter direito a nenhuma receita, o que aumentava sensivelmente o custo de capital. Com a possibilidade de recebimento do aporte durante a fase de investimentos, este custo é diminuído de forma relevante.

(grifamos)

Visando mitigar uma ineficiência econômica, as alterações promovidas na Lei das PPPs acabaram por permitir que recursos sejam direcionados ao parceiro privado, alterando toda a sistemática de sua remuneração. $\mathrm{Na}$ vigência da redação original o parceiro privado estava fadado a aportar um elevado volume de capital, comprometendo o fluxo de caixa da SPE no início da concessão, criando impacto negativo relevante, culminando em ônus financeiro considerável. Hoje, novos arranjos financeiros são possíveis.

Poder-se-ia dizer, então, mesmo com a nova redação, continuar proibido o pagamento de contraprestação sem a disponibilização do serviço, total ou parcialmente. Mas quer nos parecer ter sido flexibilizada esta regra pelo novo $\S 2^{\circ}$ do art. $6^{\circ}$ da Lei de PPPs.

Numa leitura mais ousada defendemos inclusive a possibilidade de adiantamento da contraprestação em si, ao menos na parcela referente ao investimento em bens reversíveis. Sendo possível explicitar qual parte da contraprestação é destinada a investimento ou remuneração de investimento em bens reversíveis, nos parece autorizada sua antecipação. Não estaríamos assim fugindo da ideia de ter a contraprestação natureza de pagamento público (pois há equivalência entre a disponibilização do serviço e o recebimento da contraprestação), pois estar-se-ia adiantando apenas a parcela relativa aos investimentos, jamais a tocante à remuneração pela prestação do serviço.

\subsubsection{Subsídio}


Nos itens anteriores tratamos dos recebimentos de recursos oriundos do parceiro público, dados em auxílio do parceiro privado, visando acudi-lo no cumprimento de seus desideratos. É espécie destes recebimentos o subsídio.

Em consulta à versão eletrônica do Grande Dicionário Houaiss da Língua Portuguesa ${ }^{94}$ obtivemos o seguinte resultado:

\author{
subsídio \sî \\ substantivo masculino \\ 1 concessão de dinheiro feita pelo governo a determinadas atividades (indústria, agricultura \\ etc.) com a finalidade de manter acessíveis os preços de seus produtos ou gêneros ou para \\ estimular as exportações do país \\ $\mathbf{2}$ quantia que o governo arbitra para obras de interesse público; subvenção \\ 3 quantia que um Estado dá a outro, em virtude de alguma aliança ou tratado \\ 4 recurso financeiro destinado a auxiliar pessoas ou instituições em dificuldades; adjutório, \\ socorro
}

Seu conteúdo semântico, portanto, se equipara ao de subvenção. Contudo, para a ciência jurídica subsídio tem outro significado. Vejamos as lições de Regis Fernandes de Oliveira ${ }^{95}$ :

\begin{abstract}
Precisemos os conceitos. Auxílio não tem conteúdo específico no direito administrativo e no direito financeiro. Auxílio é qualquer tipo de ajuda, seja no campo do direito, seja no campo do linguajar comum. É apoio, ajuda, esmola, subvenção, subsídio etc. Não tem significado exato. É vocábulo do palavreado comum do povo. Logo, não o utilizaremos com caráter técnico.

O subsídio tomou novos conteúdos com o advento da EC n. 19/98 que passou a ser a remuneração dos agentes políticos (inciso XI do art. 37, com redação dada pela EC n. 41/2003). Deve, pois, ser abandonado como palavra identificadora do auxílio fornecido através de recursos orçamentários.
\end{abstract}

\footnotetext{
Mauricio Portugal Ribeiro e Lucas Navarro Prado ${ }^{96}$, ao tratarem da concessão patrocinada (enfatizando que alguns a denominavam de "concessão subsidiada"), assim observaram:
}

\footnotetext{
94 Disponível em: <http://houaiss.uol.com.br/busca?palavra=subs\%25C3\%25ADdio >. Acesso em 10 abril 2013.

${ }^{95}$ OLIVEIRA, Regis Fernandes de. Curso de direito financeiro. 2. Ed. São Paulo: RT, 2008, p. 379.

${ }^{96}$ Op. Cit., p. 65.
} 
Em primeiro lugar, é necessário notar que inexiste na nossa legislação sobre contabilidade pública o conceito jurídico de "subsídio". Subsídio é, portanto, um conceito econômico, que, até o advento da Lei de PPP, era reconhecido no universo jurídico por meio das assim chamadas "subvenções".

Percebe-se haver uma mistura de conceitos econômicos e jurídicos, culminando com verdadeira confusão terminológica, dando a entender serem sinônimos subsídio, subvenção e auxílio. Mas não são! É o que tentaremos demonstrar nas linhas e item seguinte.

Subsídio, a nosso ver, tem aplicação como conceito jurídico em três hipóteses: $i$ ) como sinônimo de remuneração dos agentes públicos (nos termos da redação em vigor do inciso XI do art. 37 da CF); ii) nos casos de incentivos oferecidos por intermédio de atuações fiscais da Administração, como isenção de tributos (é o caso do subsídio dado pela União em meados de 2012 às montadoras de automóveis com fábricas em território nacional, ao zerar a alíquota de IPI para modelos de até $1000 \mathrm{cc})$, e; iii) como complementação tarifária ${ }^{97}$.

Subvenção remete a outras atuações administrativas, como adiante restará demonstrado.

${ }^{97}$ Exemplo desta aplicação de subsídio se pode extrair da lei que institui as diretrizes da política nacional de mobilidade urbana:

Lei Federal no. 12.587/2012:

Art. $9^{\circ} \mathrm{O}$ regime econômico e financeiro da concessão e o da permissão do serviço de transporte público coletivo serão estabelecidos no respectivo edital de licitação, sendo a tarifa de remuneração da prestação de serviço de transporte público coletivo resultante do processo licitatório da outorga do poder público.

(..)

$\S 3^{\circ}$ A existência de diferença a menor entre o valor monetário da tarifa de remuneração da prestação do serviço de transporte público de passageiros e a tarifa cobrada do usuário denomina-se déficit ou subsídio tarifário.

(...)

$\S 5^{\circ}$ Caso o poder público opte pela adoção de subsídio tarifário, o déficit originado deverá ser coberto por receitas extratarifárias, receitas alternativas, subsídios orçamentários, subsídios cruzados intrassetoriais e intersetoriais provenientes de outras categorias de beneficiários dos serviços de transporte, dentre outras fontes, instituídos pelo poder público delegante. 


\subsubsection{Subvenção}

Subvenção é instituto da ciência econômica. Seu conceito também não é claro. Regis Fernandes de Oliveira ${ }^{98}$ aponta a origem da confusão terminológica:

No inciso I do art. 19 o texto constitucional fala em subvenção, ao vedar qualquer ajuda aos cultos religiosos. Ao cuidar da fiscalização dos recursos públicos, no art. 70 fala também de subvenção e "renúncia de receita", que tem sido chamada, por muitos, como subvenção, também. No linguajar cotidiano fala-se em auxílio ou subvenção. Alguns falam em subsídio.

Tal confusão não é exclusividade brasileira. Vejamos o conceito de subvenção de Guillermo E. Fanelli Evans ${ }^{99}$ :

La subvención es um medio de fomento económico. El fomento es uma actividad del Estado "encaminhada a proteger o promover aquellas atividades, establecimientos o riquezas de los particulares u otros entes públicos que satisfagan necesidades públicas o de utilidad general”.

(...)

Finalmente, como típicos ejemplos de los medios económicos se mencionan las exenciones, diferimientos o desgravaciones fiscales, anticipos, primas, subsidios, reintegros, reembolsos, seguro de beneficios y también la subvención.

De fato, a ação resultante do oferecimento de qualquer dessas benesses econômicas se assemelham, culminando com os enganos acima explicitados. No item anterior delimitamos o campo de incidência dos subsídios. Tomaremos por subvenções os auxílios financeiros oferecidos pelo Poder Público aos que se põem a atuar em atividades de interesse público.

A própria lei define subvenções:

${ }^{98}$ Op. Cit., p. 378.

${ }^{99}$ EVANS, Guillermo E. Fanelli. Las subvenciones en las concesiones de obras y de servicios públicos. In: CASSAGNE, Juan Carlos (Coord.). Derecho administrativo, obra coletiva en homenaje al Profesor Miguel S. Marienhoff. Buenos Aires: Ed. Abeledo-Perrot, 1998, p. 915. 
Lei Federal no. 4.320/1964:

Art. 12. A despesa será classificada nas seguintes categorias econômicas:

(...)

$\S 3^{\circ}$ Consideram-se subvenções, para os efeitos desta Lei, as transferências destinadas a cobrir despesas de custeio das entidades beneficiadas, distinguindo-se como:

I - subvenções sociais, as que se destinem a instituições públicas ou privadas de caráter assistencial ou cultural, sem finalidade lucrativa;

II - subvenções econômicas, as que se destinem a empresas públicas ou privadas de caráter industrial, comercial, agrícola ou pastoril.

Desta forma, e nos termos do art. 16 da lei acima referida, serão subvenções sociais as transferências de recursos que visem a prestação de serviços essenciais de assistência social, médica e educacional. Adiante voltaremos a tratar das subvenções sociais, especificamente como forma de remuneração de entidades do terceiro setor executoras de atividades públicas.

Com relação à prestação de serviços através de PPPs, são as subvenções econômicas que ganham relevo. O destinatário dos recursos almeja o lucro, mas o art. 19 da lei em tela proíbe a subvenção a "empresa de fins lucrativos". Lembremos estarmos a tratar da possibilidade de antecipação de recursos ao parceiro privado, nos contratos de PPP, antes da disponibilização dos serviços.

Parece-nos que no tocante aos investimentos ou remuneração de investimentos em bens reversíveis, o aporte permitido pela nova redação da Lei Federal $\mathrm{n}^{\circ}$. 11.079/2004 pode ser feito via subvenção. Isso porque, não obstante o parceiro privado almejar o lucro, não estaria a Administração subvencionando a operação da atividade (parcela da concessão onde se concentra a operação superavitária), mas apenas e tão somente custeando, parcial ou totalmente, a infraestrutura necessária à prestação do serviço concedido, permitindo um aporte de recursos do concessionário exponencialmente menor, diminuindo o custo de capital e atribuindo eficiência econômica ao projeto. 


\section{OUTROS}

MODELOS

\section{CONTRATUAIS}

8.1. Contratos do terceiro setor: 8.1.1. Contrato de gestão: 8.1.2. Termo de parceria; 8.2. Convênio público: 8.2.1. Contrato de repasse; 8.3. Contrato de arrendamento; 8.4. Contrato de franquia; 8.5. Concessão de radiodifusão; 8.6. Concessão urbanística; 8.7. Permissão; 8.8. Autorização contratual.

Atualmente uma nova gama de contratos vem ganhando importância no cotidiano da Administração Pública brasileira. Os modelos que adiante serão analisados integram, nas lições de Fernando Dias Menezes de Almeida ${ }^{100}$, módulos convencionais necessários para a criação de situação jurídica, dividindo-se entre módulos convencionais de cooperação (ressalta a ideia de atuação conjunta para um mesmo fim) e módulos convencionais de concessão (onde impera a ideia de transferência).

${ }^{100}$ ALMEIDA, Fernando Dias Menezes de. Contrato administrativo. São Paulo: Quartier Latin, 2012, p. 236 et. seq. 
Em ambas as situações o objetivo a ser alcançado é o mesmo: a consecução de uma atividade pública. Neste desiderato é possível particulares virem em auxílio da Administração; todavia, como já analisado em capítulo anterior, não pode o particular executar atividade pública sem que por isso seja remunerado, ou disponha de fonte de custeio perene e sólida. Vejamos como essa remuneração é feita em cada espécie de contrato.

\subsection{CONTRATOS DO TERCEIRO SETOR}

É crescente a importância do terceiro setor na consecução de atividades públicas no Brasil atual. Hoje grande parcela do PIB nacional é destinada a entidades integrantes dessa "categoria", visando a implementação de políticas públicas especialmente voltadas às esferas mais pobres da população.

Antes de tratarmos dos instrumentos de remuneração desses agentes, é necessária uma breve explanação acerca da sua natureza, objetivos e espécies de vínculos possíveis de se firmar com o Estado.

Afinal, o que é terceiro setor? Gustavo Henrique Justino de Oliveira ${ }^{101}$ assim o definiu:

Entende-se por Terceiro Setor o conjunto de atividades voluntárias desenvolvidas por organizações privadas não-governamentais e sem ânimo de lucro (associações ou fundações), realizadas em prol da sociedade, independentemente dos demais setores (Estado e mercado), embora com eles possa firmar parcerias e receber investimentos (públicos e privados).

101 OLIVEIRA, Gustavo Henrique Justino de. Estado contratual, direito ao desenvolvimento e parceria público-privada. In: TALAMINI, Eduardo; JUSTEN, Mônica Spezia (Coords.). Parcerias público-privadas, um enfoque multidisciplinar. São Paulo: RT, 2005, p. 86, nota de rodapé nº 5. 
Podemos concluir, das lições acima transcritas, ser o primeiro setor ocupado pelo Estado, o segundo setor pelas entidades privadas com fins lucrativos (mercado) e o terceiro setor pelas organizações da sociedade civil que não almejam o lucro. Muito se questiona acerca das razões pelas quais houve um aumento exponencial dessas entidades. Sílvio Luís Ferreira da Rocha ${ }^{102}$ assim trata de tal fenômeno:

\begin{abstract}
Não há uma única explicação para o crescimento das entidades do Terceiro Setor. No Brasil, seu crescimento resulta do incentivo dado pela "Reforma do Estado" à atividade administrativa de fomento, em decorrência da redescoberta do princípio da subsidiariedade, e da suposta crise do Estado enquanto prestador eficiente de serviços públicos. Muito embora, Terceiro Setor e atividade administrativa de fomento sejam assuntos distintos, a redescoberta da atividade administrativa de fomento pode ser vista como a maior responsável pelo crescimento no Brasil dos entes que integram o Terceiro Setor - pelo menos daquelas entidades que buscam incentivos do Estado para executar seus objetivos sociais.
\end{abstract}

Percebe-se, portanto, que a atuação do Terceiro Setor como partícipe na consecução das atribuições do Poder Público tangencia, senão se inclui, na atividade de fomento. Como tratado no início do presente trabalho, fomento é atividade típica e indelegável da Administração. Não se está aqui a atribuir ao Terceiro Setor o fomento em si - buscamos apenas demonstrar decorrer sua atuação, em grande parte, da prática do fomento, ou seja, da ação administrativa tendente a promover a atuação privada que satisfaça necessidade coletiva. Ao discorrer sobre a atividade estatal de fomento Janaina Schoenmaker ${ }^{103}$ assim registrou:

Entre as atividades de fomento do Estado, destacam-se: concessão de títulos honoríficos (utilidade pública), concessão de vantagens tributárias (imunidades e isenções) e transferência de recursos mediante autorização em lei (por exemplo, orçamentária) ou celebração de parcerias (como convênios, contratos de gestão etc.).

Apenas as transferências voluntárias de recursos serão alvo de nossa análise, pois a concessão de vantagens tributárias (imunidades e isenções) não integra a noção de remuneração adotada para o presente trabalho.

\footnotetext{
${ }^{102}$ ROCHA, Sílvio Luís Ferreira da. Terceiro setor. 2. Ed. São Paulo: Malheiros, 2006, p. 16.

${ }^{103}$ SCHOENMAKER, Janaina. Controle das parcerias entre o estado e o terceiro setor pelos tribunais de contas. Belo Horizonte: Fórum, 2011, pp. 53/54.
} 
Dizemos transferências voluntárias pois aqui não estão incluídos recursos das transferências obrigatórias, decorrentes da Constituição ou da Lei. Essas transferências voluntárias são intituladas de "auxílios, contribuições e subvenções sociais, e nem sempre decorrem de instrumentalização de parcerias" 104 .

O auxílio está previsto no $\S 6^{\circ}$ do art. 12 da Lei Federal nº 4.320/1964 (estatui normas gerais de direito financeiro para elaboração e controle dos orçamentos e balanços da União, dos Estados, dos Municípios e do Distrito Federal) e é assim tratado: transferências de capital, derivadas diretamente da Lei de Orçamento, que visam investimentos, independentemente de contraprestação direta em bens ou serviços por quem as recebe. Pode ser destinado a entidades de direito privado sem fins lucrativos, nos termos do disposto no Decreto Federal nº. 93.872/1986.

Para se efetivar o auxílio não há necessidade de se instrumentalizar a relação público/privado, pois derivando diretamente da Lei de Orçamento, prescinde de acordo escrito ou de lei especial. As leis de diretrizes orçamentárias costumam trazer algumas especificidades para que se faça possível a concessão de auxílio ${ }^{105}$.

Com relação às contribuições, parece-nos diferir, com relação ao auxílio, apenas quanto à origem de sua autorização. Enquanto o auxílio decorre da Lei de Orçamento, a contribuição decorre de lei especial. Vale apontar, outrossim, que tanto o auxílio quanto a contribuição tem por finalidade precípua o custeio de "despesas de capital, isto é, aquelas que podem gerar serviços, riquezas, e produzir um incremento ao Produto Nacional" ${ }^{\prime 106}$.

\footnotetext{
${ }^{104}$ SCHOENMAKER, Janaina. Op. Cit., p. 54.

${ }^{105} \mathrm{Na}$ LDO de 2008 consta como requisito para concessão de auxílio que os recursos sejam utilizados na: $i$ ) aquisição e instalação de equipamentos, e obras de adequação física necessárias à instalação dos referidos equipamentos; ii) aquisição de material permanente; ou iii) reformas e conclusão de obra em andamento, cujo início tenha ocorrido com recursos dos Orçamentos Fiscal e da Seguridade Social, vedada a destinação de recursos para ampliação do projeto original.

${ }^{106}$ ROCHA, Sílvio Luís Ferreira da. Op. Cit., p. 47.
} 
Diferente são as subvenções. $\mathrm{O} \S 3^{\circ}$ do art. 12 da Lei Federal nº $.4 .320 / 1964$ define subvenções como transferências destinadas a cobrir despesas de custeio das entidades beneficiadas. Divide-as em duas espécies: $i$ ) subvenções sociais, destinadas a instituições públicas ou privadas de caráter assistencial ou cultural, sem finalidade lucrativa; ii) subvenções econômicas, direcionadas a empresas públicas ou privadas de caráter industrial, comercial, agrícola ou pastoril.

Em outras palavras, os recursos oriundos das subvenções se prestam apenas e tão somente a financiar a operação da atividade executada pela entidade receptora. Não acode à construção de infraestrutura ou aquisição de equipamentos.

No caso das subvenções sociais, sua concessão independe da existência de legislação especial. Da leitura do art. 16 da Lei Federal no . 4.320/1964 colhe-se a ideia de subsidiariedade, quando estabelece só ser possível o repasse de subvenções sociais quando for mais econômico para o Estado entregar os serviços à iniciativa privada do que executálos diretamente.

Aponta também, em seu Parágrafo único, que o valor das subvenções, quando possível, será calculado com base em unidades de serviços efetivamente prestados ou postos à disposição dos interessados, obedecidos os padrões mínimos de eficiência previamente fixados.

Por fim, apenas instituições cujas condições de funcionamento forem julgadas satisfatórias pelos órgãos oficiais de fiscalização farão jus ao recebimento de subvenções (art. 17, Lei Federal nº. 4.320/1964). 
As subvenções econômicas, por sua vez, não obstante também visarem o custeio de despesas operacionais das executoras de atividade de interesse coletivo, apresentam algumas restrições, dentre elas a exigência de legislação específica, nos casos onde a beneficiária seja empresa que almeje o lucro.

A forma mais usual de remuneração do terceiro setor se dá, portanto, através das subvenções sociais. Nos termos do Decreto $\mathrm{n}^{\circ}$. 93.872/1986, o repasse deve ser feito por meio de rede bancária oficial. Já a Instrução Normativa STN nº 01/97 estabeleceu que tal repasse será efetivado via parceria, independentemente de lei específica.

Adiante serão apresentados os instrumentos pelos quais as transferências de valores poderão ser formalizadas.

\subsubsection{Contrato de gestão}

Para o presente trabalho, não obstante se poder cogitar de contratos de gestão firmados entre a Administração Direta e entidades da Administração Indireta ${ }^{107}$, interessa apenas o modelo de contrato de gestão previsto na Lei Federal nº 9.637/1998 que, em seu artigo 5', assim determina: "para os efeitos desta Lei, entende-se por contrato de gestão o instrumento firmado entre o Poder Público e a entidade qualificada como

\footnotetext{
${ }^{107}$ Maria Sylvia Zanella Di Pietro, em trabalho específico sobre o tema, assim fez constar: "No direito brasileiro, adotou-se o modelo francês, mas se optou pela denominação de "contratos de gestão", já consagrada no direito positivo e em alguns trabalhos doutrinários. Em relação às empresas estatais, houve por parte do Governo o mesmo objetivo que inspirou o sistema francês, de contratualizar o controle que a Administração exerce sobre as entidades da Administração Indireta. A vantagem existe para as duas partes: para o Estado, porque submete as empresas ao cumprimento dos programas ou objetivos governamentais; para as empresas, porque ganham maior autonomia de gestão, sujeitando-se a um controle de resultados, ao invés do controle puramente formal a que se sujeitam normalmente. Aliás, o controle de resultados é essencial nesse tipo de contrato, porque é a única maneira de verificar-se a consecução dos objetivos governamentais.” DI PIETRO, Maria Sylvia Zanella. Contratos de gestão. Contratualização do controle administrativo sobre a administração indireta e sobre as organizações sociais. Disponível no sítio eletrônico do Centro de Estudos da Procuradoria Geral do Estado de São Paulo: <http://www.pge.sp.gov.br/centrodeestudos/revistaspge/revista2/artigo9.htm>. Acesso em 23 abril 2013.
} 
organização social, com vistas à formação de parceria entre as partes para fomento e execução de atividades relativas às áreas relacionadas no artigo $1^{\text {or }}$.

O artigo $1^{\circ}$, por sua vez, faz referência a atividades públicas, especificamente: ensino, pesquisa científica, desenvolvimento tecnológico, proteção e preservação do meio ambiente, cultura e saúde. Percebe-se, nestes gêneros, estar englobada boa parte das atribuições típicas do Poder Público. Desta forma, é de se notar a importância que este instrumento vem adquirindo desde a promulgação da referida legislação.

No art. 12 constam as formas de remuneração da entidade a ser contratada pelo Estado: poderão ser destinados recursos orçamentários e bens públicos necessários ao cumprimento do contrato de gestão. Esse particular obrigatoriamente será uma organização social, estando previstos, na própria lei, os requisitos a serem atendidos pela pessoa jurídica de direito privado que almeja obter do Poder Público essa qualificação. Não cabe neste trabalho uma análise minuciosa acerca da sua natureza, seus objetivos e consequências dessa qualidade. Cumpre apenas apontar serem os contratos de gestão firmados através das Organizações Sociais.

O contrato de gestão é, hoje, importante instrumento de atuação do Estado. Parece-nos ter natureza de contrato administrativo (e não de contrato da Administração ${ }^{108}$ ),

\footnotetext{
${ }^{108}$ Guillermo Andrés Muñoz, tratando do assunto: contratos administrativos y los contratos privados de la Administración. contractuales.

(...) contractual expresa.

Entre esos poderes se destacan:

a) El de vigilancia y dirección.

b) El de modificación unilateral de los contratos.

c) El de aplicación unilateral de sanciones.

d) El de rescisión unilateral."
}

"Sin embargo, la figura del contrato administrativo es sustancialmente polémica (García de Enterría).

En mi país, uno de los aspectos más espinosos de esa polémica es el que se refiere a si todos los contratos que celebra la Administración, tienen idéntica naturaleza jurídica, o si existen dos categorías diferentes: los

Un importante sector de la doctrina postula la existencia de diferencias sustantivas entre esos tipos

Suele sostenerse que existen ciertas reglas proprias del régimen general de los contratos administrativos, que permiten diferenciarlos de los contratos privados de la Administración. Estas reglas generales, consagrarían diversas prerrogativas en favor de la Administración, que pueden ser ejercidas aun a falta de estipulación 
pois a ele se aplicam os princípios que regem a atuação administrativa $(\mathrm{CF}$, art. 37, caput e Lei Federal $\mathrm{n}^{\mathrm{o}}$. 9.637/1998, art. $7^{\circ}$ ). Ademais, salvo as hipóteses de dispensa e inexigibilidade, a licitação será imprescindível.

O Estado, ao firmar contrato desta natureza, está atuando como fomentador das atividades de ensino, pesquisa científica, desenvolvimento tecnológico, proteção e preservação do meio ambiente, cultura e saúde. Agindo a entidade em auxílio à Administração, pelo contrato de gestão estará submetida ao programa estabelecido pelo Poder Público, recebendo ajuda financeira e estrutural para isso.

Ganha importância a atuação dos órgãos de controle, visando averiguar se os objetivos almejados pela parceria estão efetivamente sendo concretizados. A lei não traz previsão quanto ao prazo de duração do contrato, aplicando-se então as disposições da Lei Federal $n^{\circ}$. 8.666/1993. Extingue-se com o término de seu prazo ou com o atingimento de seus objetivos, caso a atividade almejada não seja de prestação continuada.

\subsubsection{Termo de parceria}

Termo de Parceria é o nome dado ao instrumento passível de ser firmado entre o Poder Público e as entidades qualificadas como Organizações da Sociedade Civil de Interesse Público, destinado à formação de vínculo de cooperação entre as partes, para o fomento e a execução das atividades arroladas nos incisos do art. $3^{\circ}$ da Lei Federal $\mathrm{n}^{\circ}$. $9.790 / 1999^{109}$.

(MUÑOZ, Guillermo Andrés. Contratos de la administración. In: MUÑOZ, Guillermo Andrés; GRECCO, Carlos Manuel. Fragmentos y testimonios del derecho administrativo. Buenos Aires: Ad-Hoc, 1999, pp. 333/343).

${ }^{109}$ Lei Federal no. 9.790/1999:

Art. $3^{\circ} \mathrm{A}$ qualificação instituída por esta Lei, observado em qualquer caso, o princípio da universalização dos serviços, no respectivo âmbito de atuação das Organizações, somente será conferida às pessoas jurídicas de 
Apesar de muito se assemelhar ao contrato de gestão, diferem com relação à sua amplitude e às partes envolvidas. No contrato de gestão teremos sempre uma OS; no termo de parceria uma OSCIP. O contrato de gestão abrange todas as atividades da entidade beneficiária; o termo de parceria visa apenas a obtenção de ajuda do Poder Público para desenvolvimento de alguma atividade de interesse público, combinado com recursos próprios ou de terceiros, sem comprometimento da autonomia e independência da $\operatorname{OSCIP}^{110}$.

Também não iremos nos ater às exigências de qualificação de uma entidade como OSCIP. Basta dizer que as OSCIPs "são pessoas jurídicas de direito privado, instituídas por particulares, sem objetivo de lucro; desempenham serviços sociais não exclusivos do Estado, porém com a colaboração dele; por essa razão, sujeitam-se a controle de resultados pela Administração Pública, com a colaboração da própria sociedade, e ao controle do Tribunal de Contas no que diz respeito à aplicação de recursos públicos; seu regime jurídico é predominantemente de Direito Privado, porém parcialmente derrogado por normas de Direito Público, especialmente no que diz respeito

direito privado, sem fins lucrativos, cujos objetivos sociais tenham pelo menos uma das seguintes finalidades:

I - promoção da assistência social;

II - promoção da cultura, defesa e conservação do patrimônio histórico e artístico;

III - promoção gratuita da educação, observando-se a forma complementar de participação das organizações de que trata esta Lei;

IV - promoção gratuita da saúde, observando-se a forma complementar de participação das organizações de que trata esta Lei;

V - promoção da segurança alimentar e nutricional;

VI - defesa, preservação e conservação do meio ambiente e promoção do desenvolvimento sustentável;

VII - promoção do voluntariado;

VIII - promoção do desenvolvimento econômico e social e combate à pobreza;

IX - experimentação, não lucrativa, de novos modelos sócio-produtivos e de sistemas alternativos de produção, comércio, emprego e crédito;

X - promoção de direitos estabelecidos, construção de novos direitos e assessoria jurídica gratuita de interesse suplementar;

XI - promoção da ética, da paz, da cidadania, dos direitos humanos, da democracia e de outros valores universais;

XII - estudos e pesquisas, desenvolvimento de tecnologias alternativas, produção e divulgação de informações e conhecimentos técnicos e científicos que digam respeito às atividades mencionadas neste artigo.

Parágrafo único. Para os fins deste artigo, a dedicação às atividades nele previstas configura-se mediante a execução direta de projetos, programas, planos de ações correlatas, por meio da doação de recursos físicos, humanos e financeiros, ou ainda pela prestação de serviços intermediários de apoio a outras organizações sem fins lucrativos e a órgãos do setor público que atuem em áreas afins.

${ }^{110}$ FURTADO, Lucas Rocha. Curso de direito administrativo. Belo Horizonte: Fórum, 2007, p. 349. 
ao controle. As atividades que exercem não são serviços públicos; mas são atividades de interesse público que o Estado se limita a fomentar"111.

Sua contratação também deriva de processo licitatório, ressalvadas as hipóteses de dispensa e inexigibilidade de licitação. Nas lições de Janaina Schoenmaker ${ }^{112}$ :

Sob os aspectos legais, o termo de parceria encontra-se previsto na Lei Federal n ${ }^{\circ}$. 9.790/99, no Decreto ${ }^{\circ}$. 3.100/99 e na Portaria MJ nº. 361/99, sendo passível, como se viu, de ser celebrado especificamente com entidades qualificadas como OSCIPs, contendo a previsão de programa de trabalho (proposto pela entidade), metas e resultados a serem atingidos, prazos de execução, critérios objetivos de avaliação de desempenho a serem utilizados como indicadores de resultado e a previsão de receitas e despesas para o seu cumprimento.

Percebe-se, portanto, muito se assemelhar ao contrato de gestão. Vale lembrar, todavia, que tanto OSs quanto OSCIPs podem firmar, além dos respectivos contratos de gestão e termos de parceria, convênios. Vejamos:

\subsection{CONVÊNIO PÚBLICO}

Dentre as obras consultadas nos pareceu mais didático o conceito de convênio público formulado por Marçal Justen Filho ${ }^{113} 114$ :

${ }^{111}$ DI PIETRO, Maria Sylvia Zanella. Privatização e o novo exercício de funções públicas por particulares. In: MOREIRA NETO, Diogo de Figueiredo (Coord.). Uma avaliação das tendências contemporâneas do direito administrativo. Rio de Janeiro: Renovar, 2003, p. 436.

${ }_{112}$ Op. Cit., p. 71.

${ }^{113}$ Op. Cit., p. 422.

${ }^{114}$ Decreto $^{\circ}$. 6.170/2007:

Art. $1^{\circ}$ Este Decreto regulamenta os convênios, contratos de repasse e termos de cooperação celebrados pelos órgãos e entidades da administração pública federal com órgãos ou entidades públicas ou privadas sem fins lucrativos, para a execução de programas, projetos e atividades de interesse recíproco que envolvam a transferência de recursos oriundos do Orçamento Fiscal e da Seguridade Social da União. (Redação dada pelo Decreto ${ }^{\circ}$. 6.428, de 2008).

$\S 1^{\circ}$ Para os efeitos deste Decreto, considera-se:

I - convênio - acordo, ajuste ou qualquer outro instrumento que discipline a transferência de recursos financeiros de dotações consignadas nos Orçamentos Fiscal e da Seguridade Social da União e tenha como 
O convênio público consiste numa avença em que dois ou mais sujeitos, sendo ao menos um deles integrantes da Administração Pública, comprometem-se a atuar de modo conjugado para a satisfação de necessidades de interesse coletivo, sem intento de cunho lucrativo.

Alguns doutrinadores não enxergam o convênio como espécie de contrato. Vejamos as lições de Maria Sylvia Zanella Di Pietro ${ }^{115} 116$ :

O convênio não constitui modalidade de contrato, embora seja um dos instrumentos de que o Poder Público se utiliza para associar-se com outras entidades públicas ou com entidades privadas.

(...)

O convênio tem em comum com o contrato o fato de ser um acordo de vontades. Mas é um acordo de vontades com características próprias. Isto resulta da própria Lei $\mathrm{n}^{\mathrm{o}}$. 8.666/93, quando, no art. 116, caput, determina que suas normas se aplicam aos convênios "no que couber". Se os convênios tivessem natureza contratual, não haveria necessidade dessa norma, porque a aplicação da Lei já decorreria dos artigos $1^{\circ}$ e $2^{\circ}$.

Continua a autora listando as diferenças entre contrato e convênio, a corroborar seu posicionamento. Marçal Justen Filho ${ }^{117}$, considerando não decorrer dos convênios benefícios ou vantagens econômicas, conclui a eles não se aplicar as regras genéricas sobre contratação administrativa. Admite, todavia, se aplicarem regras próprias desse modelo de contratação, pois produz efeitos vinculantes para as partes.

Odete Medauar ${ }^{118}$, ao tratar dos convênios e consórcios, assim fez notar:

partícipe, de um lado, órgão ou entidade da administração pública federal, direta ou indireta, e, de outro lado, órgão ou entidade da administração pública estadual, distrital ou municipal, direta ou indireta, ou ainda, entidades privadas sem fins lucrativos, visando a execução de programa de governo, envolvendo a realização de projeto, atividade, serviço, aquisição de bens ou evento de interesse recíproco, em regime de mútua cooperação;

115 Op. Cit., p. 336.

116 Alexandre Santos de Aragão também não considera o convênio um contrato: "Os convênios, como não são contratos, não estão sujeitos à licitação, aplicando-se-lhes apenas o art. 116 da Lei no . 8.666/93, a eles especificamente dirigido, enquanto norma geral de Direito Financeiro de eficácia nacional, impositivo de um cronograma de desembolso". (ARAGÃO, Alexandre Santos de. Curso de direito administrativo. Rio de Janeiro: Forense, 2012, p. 289).

${ }^{117}$ Op. Cit., p. 422.

${ }^{118}$ Op. Cit., pp. 227/228. 
Quanto à natureza, parte da doutrina publicista pátria distingue convênios de contratos, aplicando-se aos consórcios o que se afirma para os convênios. (...)

$(\ldots)$

Vários argumentos em ressalva a tais diferenças poderiam ser expostos. (...)

(...)

A dificuldade de fixar diferenças entre contrato, de um lado, e convênio e consórcio, de outro, parece levar a concluir que são figuras da mesma natureza, pertencentes à mesma categoria, a contratual. A característica dos convênios e consórcios está na sua especificidade, por envolverem duas ou mais entidades estatais ou pelo tipo de resultado que pretendem atingir com o acordo firmado. O mesmo vale para os consórcios. Daí o teor do art. $4^{\circ}$, XII, da Lei $11.107 / 2005$, relativo ao direito do consorciado, quando adimplente com suas obrigações, de exigir o pleno cumprimento das cláusulas do contrato de consórcio.

E, corroborando o entendimento de que o convênio é espécie da categoria contrato, Fernando Dias Menezes de Almeida ${ }^{119}$ observou:

O convênio é, no Brasil, no mais das vezes, instrumento para a criação de situação subjetiva ainda que envolvendo interesses convergentes - e, nesse aspecto, merece receber o mesmo tratamento jurídico do contrato (no sentido estrito que lhe dá tradicionalmente a doutrina).

Parece assistir razão àqueles que tomam o convênio como contrato. De fato seus elementos caracterizadores não estão estampados de forma tão clara quanto num contrato administrativo tradicional. Todavia, basta uma mirada sob outro enfoque para aferir exatamente os seus aspectos identificadores. A título de exemplo, podemos visualizar interesses antagônicos envolvidos neste tipo de contratação (para alguns os interesses envolvidos no convênio são sempre convergentes). Enquanto à Administração incumbe a busca pelo interesse público, o particular se pauta pelo viés assistencialista (mesmo quando este, por vezes, não acuda ao interesse público - não se presta a eliminar as causas da carência, mas sim a organizar e prestar assistência a membros ou camadas mais carentes).

Outra discussão que merece rápida menção é acerca da necessidade de licitação para sua efetivação. Neste particular, nos parece ser regra a obrigatoriedade de um procedimento apto a propiciar a disputa e a busca pela melhor proposta (apesar de não ser a conduta mais adotada na prática). Continuam aplicáveis as hipóteses de dispensa e as condições de inexigibilidade, típicas do processo licitatório tradicional. Contudo, em

${ }^{119}$ Op. Cit., p. 243. 
situações de normalidade, mesmo frente à especificidade do objeto, à natureza de sua finalidade e de não visarem as possíveis licitantes fins lucrativos, é de rigor a averiguação comparativa da qualidade dos serviços que serão oferecidos ${ }^{120} 121122$.

O convênio, apesar de atualmente se proliferar como forma de contratualização da prestação de serviços públicos, não é instrumento capaz de delegá-los à iniciativa privada. Aponta Maria Sylvia Zanella Di Pietro ${ }^{123}$ :

O convênio não se presta à delegação de serviço público ao particular, porque essa delegação é incompatível com a própria natureza do ajuste; na delegação ocorre a transferência de atividade de uma pessoa para outra que não a possui; no convênio, pressupõe-se que as duas pessoas têm competências comuns e vão prestar mútua colaboração para atingir seus objetivos.

Assiste razão à autora, pois a delegação do serviço implicaria em assunção de direitos pela iniciativa privada, ausente na espécie. Há vozes no sentido de que o convênio é veículo de delegação de serviço público: "se o ente público incumbido do

${ }^{120}$ Para Maria Sylvia Zanella Di Pietro a licitação não é exigida na celebração de convênios: "Quanto à exigência de licitação para a celebração de convênios, ela não se aplica, pois neles não há viabilidade de competição; esta não pode existir quando se trata de mútua colaboração, sob variadas formas, como repasse de verbas, uso de equipamentos, recursos humanos, imóveis. Não se cogita de preço ou de remuneração que admita competição". (DI PIETRO, Maria Sylvia Zanella. Direito administrativo. 22. Ed. São Paulo: Atlas, 2009, p. 339).

${ }^{121}$ Odete Medauar entende ser necessária a licitação: "No tocante aos convênios entre órgãos e entes estatais e entidades particulares, o que, sobretudo, fundamenta a desobrigação de licitação é a especificidade do objeto e da finalidade. No entanto, se a Administração pretender realizar convênio para resultado e finalidade que poderão ser alcançados por muitos, deverá ser realizada licitação ou se abrir a possibilidade de conveniar sem limitação, atendidas as condições fixadas genericamente. Se assim não for, haverá ensejo para burla, acobertada pela acepção muito ampla que se queira dar aos convênios. Alguns casos ocorrem na prática, nos quais, a título de convênio, obras são contratadas sem licitação e pessoas são investidas em funções e empregos públicos sem concurso ou seleção". (MEDAUAR, Odete. Direito administrativo moderno. 12. Ed. São Paulo: RT, 2008, p. 228).

${ }^{122}$ Vale, por fim, a transcrição das lições de Fernando Dias Menezes de Almeida sobre a questão: "Ora, na medida em que o convênio é meio para se estabelecerem situações subjetivas, por que não se valer, ainda que não estritamente das modalidades previstas na Lei $\mathrm{n}^{\circ} .8 .666 / 93$, de instrumentos que permitam garantir a isonomia dos que pretendam relacionar-se com a Administração e, ao mesmo tempo, permitam a esta escolher uma melhor proposta. Mesmo se tratando de entidades sem fins lucrativos a se conveniarem, e também de situações em que a Administração não perceba benefício econômico, pode haver critérios técnicos para se avaliar comparativamente a qualidade de propostas de potenciais interessados em um convênio. É certo que podem ocorrer casos de convênios que justifiquem, por suas peculiaridades, a contratação direta. Mas isso não afasta, como regra geral, a licitação. Aliás, como fartamente se acompanha pelos noticiários, os convênios (ou figuras congêneres) com instituições privadas aparecem dentre as figuras mais citadas em matéria de instrumentos envolvidos em desvio de recursos públicos". (ALMEIDA, Fernando Dias Menezes de. Contrato administrativo. São Paulo: Quartier Latin, 2012, p. 245).

${ }^{123}$ Op. Cit., p. 338. 
serviço deixar de prestá-lo diretamente para, por exemplo, passar a financiar entidade conveniada para fazê-lo, poderemos estar diante de uma modalidade de delegação de serviço público, ainda que bem distinta da concessão, em razão, por exemplo, da possibilidade de denúncia unilateral por qualquer das partes sem indenização" ${ }^{\text {124 }}$. Estaremos, nestes casos, diante de delegações não decorrentes do fundamento concessório estampado no art. 175, mas sim no art. 241 da Constituição Federal. Tal possibilidade, entretanto, não será alvo de nossa análise, pois não envolverá particular executando atividade pública.

Toca ao presente estudo os convênios firmados com particulares. Apesar de não entendermos como delegada pelo Estado a atividade por eles prestada, é fato que, em boa parte das vezes, executam atividade pública. São comuns os convênios cujo objeto é a prestação de serviços contínuos (ligados normalmente à área da educação, saúde e desportos $)^{125}$.

Como dito alhures, a entidade a ser conveniada com a Administração não poderá visar o lucro ${ }^{126}$. Esta afirmação, todavia, não invalida a ideia de que algum interesse privado possa haver na consecução deste contrato. Diógenes Gasparini ${ }^{127}$, saudoso administrativista, tratou desta particularidade dos convênios:

O convênio pode ter por objeto qualquer coisa (obra, serviço, atividade, uso de certo bem), desde que encarne, relacionado com cada partícipe, um interesse público. A sua natureza administrativa impede que o objeto apenas consagre o interesse privado que o partícipe particular deseja ver privilegiado com a ajuda do convenente público. Pode ocorrer que o objeto, além de encarnar um interesse público, também sintetize um interesse particular, como é o caso do convênio em que um dos partícipes é pessoa privada. Nesse caso, não há qualquer óbice à constituição do convênio. Com efeito, se assim não se admitisse, seria improvável que uma pessoa privada tivesse algum interesse em conveniar com a Administração Pública.

\footnotetext{
${ }^{124}$ ARAGÃO, Alexandre Santos de. Op. Cit., p. 340.

125 Para maiores informações acerca dos convênios firmados pelo Governo Federal, acessar o "Portal dos Convênios do Governo Federal": <https://www.convenios.gov.br $>$.

${ }^{126}$ Não obstante o inciso I do $\S 1^{\circ}$ do art. $1^{\circ}$ do Decreto $n^{\circ}$. 6.170/2007 dispor só poder os convênios serem firmados com entidades privadas sem fins lucrativos, nos parece que a disciplina proposta pela legislação relativa à matéria permite inferir ser possível a contratação de convênio com entidade privada com fins lucrativos, desde que na esfera daquele convênio não esteja almejando o lucro. Este raciocínio decorre também da observação de um fato: qual a diferença prática de ser firmar um convênio entre o Banco Bradesco S.A. ou a Fundação Bradesco?

${ }^{127}$ GASPARINI, Diógenes. Direito administrativo. 6. Ed. São Paulo: Saraiva, 2001, p. 376.
} 
Ousamos afirmar que considerável parcela dos convênios firmados com entidades privadas tem, por interesse secundário, questões políticas ou fiscais (residindo aí o interesse privado daquele que não almeja o lucro). Mas, mesmo não almejando lucro, as entidades privadas que prestam as atividades objeto dos convênios são remuneradas, ou custeadas, pois não atuam com recursos próprios.

Em regra esse custeio advém de repasses do Poder Público com quem se firmou o convênio. Para Maria Sylvia Zanella Di Pietro ${ }^{128}$ :

\begin{abstract}
Essa necessidade de controle se justifica em relação aos convênios precisamente por não existir neles a reciprocidade de obrigações presente nos contratos; as verbas repassadas não têm a natureza de preço ou remuneração que uma das partes paga à outra em troca de benefício recebido. Vale dizer que o dinheiro assim repassado não muda a natureza por força do convênio; ele é utilizado pelo executor do convênio, mantida a sua natureza de dinheiro público. Por essa razão, é visto como alguém que administra dinheiro público, estando sujeito ao controle financeiro e orçamentário previsto no artigo 70, parágrafo único, da Constituição.
\end{abstract}

Em recente dissertação, trabalho com o qual Carolina Caiado Lima obteve o título de mestre em Direito do Estado perante a Faculdade de Direito da Universidade de São Paulo, a autora tratou de diferenciar as espécies de convênios, suas finalidades e terminologias, culminando com a análise das transferências de recursos públicos a entidades privadas sem fins lucrativos. Nesta oportunidade deixou consignado: "a legislação federal permite tanto a celebração de convênios quanto de contratos de repasse para concessão de subvenções, auxílios e contribuições" ${ }^{129}$. Desta forma, no bojo do próprio convênio devem estar regulados os repasses de recursos - seu cronograma de desembolso, suas formas de controle e suas regras de prestação de contas ${ }^{130}$.

\footnotetext{
${ }^{128}$ Op. Cit., p. 339.

${ }^{129}$ LIMA, Carolina Caiado. O convênio administrativo colaborativo para transferência de recursos públicos a entidades privadas sem fins lucrativos como instrumento dos mecanismos diretos de fomento público. Dissertação de Mestrado. Faculdade de Direito da Universidade de São Paulo, 2010, p. 92.

${ }^{130}$ Decreto Federal no. 93.872/1986:

Art. 66. Quem quer que receba recursos da União ou das entidades a ela vinculadas, direta ou indiretamente, inclusive mediante acordo, ajuste ou convênio, para realizar pesquisas, desenvolver projetos, estudos, campanhas e obras sociais ou para qualquer outro fim, deverá comprovar o seu bom e regular emprego, bem como os resultados alcançados.
} 
Corrobora tal entendimento o disposto no art. $6^{\circ}$ do Decreto $n^{\circ} .6 .170 / 2007$ : constitui cláusula necessária em qualquer convênio dispositivo que indique a forma pela qual a execução do objeto será acompanhada pelo concedente. Deverão se submeter a controle as metas de execução física do objeto, os repasses de recursos e sua respectiva aplicação. Carolina Caiado Lima ${ }^{131}$ aponta algumas particularidades a serem observadas na lida com os recursos advindos desses repasses:

Os recursos devem ser movimentados em conta vinculada, cujos rendimentos podem ser revertidos para as ações do projeto aprovado; há obrigações de prestação de contas e execução do cronograma físico-financeiro; a liberação das parcelas dos recursos é condicionada à aprovação de prestação de contas parciais.

Todavia, existem situações nas quais os repasses são instrumentalizados não pelo próprio contrato de convênio, mas sim pelo denominado "contrato de repasse".

\subsubsection{Contrato de repasse}

A legislação atinente ao tema é bastante confusa, atribuindo incumbências, a nosso ver, idênticas aos "convênios" e "contratos de repasse". O Decreto no . 6.170/2007 conceitua, no inciso II do $\S 1^{\circ}$ do art. $1^{\circ}$, o contrato de repasse: instrumento administrativo por meio do qual a transferência dos recursos financeiros se processa por intermédio de instituição ou agente financeiro público federal, atuando como mandatário da União.

$\S 1^{\circ}$ A prestação de contas de aplicação de subvenção social ou auxílio será apresentada à unidade concedente dentro de 60 dias após a aplicação, não podendo exceder ao último dia útil do mês de fevereiro do ano subsequente ao do recebimento, e será constituída de relatório de atividades e demonstração contábil das origens e aplicações de recursos, referentes ao ano do recebimento, visados por autoridade publica local, observados os modelos aprovados pelo órgão Central do Sistema de Controle Interno.

${ }^{131}$ Op. Cit., p. 92. 
Desta forma, é possível concluir que subvenções, auxílios e contribuições podem ser concedidas a entidades privadas tanto por intermédio do contrato de convênio quanto pelo contrato de repasse. Sendo assim, no que diferem? Guilherme Henrique de La Roque Almeida ${ }^{132}$ responde a questão:

O contrato de repasse é o instrumento administrativo por meio do qual a transferência de recursos financeiros se processa por intermédio de instituição ou agente financeiro público federal, atuando como mandatário da União. Observa-se que o contrato de repasse é muito semelhante ao convênio. A grande diferença entre os dois reside em que, no contrato de repasse, existe a intermediação realizada por instituição ou agente financeiro público federal, a quem caberá receber os recursos do concedente e repassá-los, devendo ser observadas determinadas condições.

\subsection{CONTRATO DE ARRENDAMENTO}

Outra espécie de contrato onde há a transferência da execução de atividades públicas a particular é o arrendamento. Nele delega-se a gestão de serviço de interesse público a particular mediante a cessão de áreas para sua exploração. Odete Medauar ${ }^{133}$ é uma das poucas juristas brasileiras que faz menção, em sua obra geral, desta modalidade contratual:

Contrato de arrendamento - mediante esse instrumento o poder público transfere a gestão operacional de um serviço público a um particular (arrendatário), para que este o explore por sua conta e risco, colocando à sua disposição um imóvel público ou um complexo de bens públicos, ligados ao serviço. Exemplo no Brasil: o contrato de arrendamento de portos ou áreas de portos, precedido de licitação, disciplinado na Lei 8.630, de 25.02.1993. Poderá ser acertado o pagamento ao poder público de importância determinada ou percentual sobre o que for recebido pelo arrendatário.

De fato o melhor modelo de arrendamento no Brasil encontra-se no setor portuário. Todavia, vale lembrar ter sido a Lei Federal $n^{\circ}$. 8.630/1993 revogada pela

\footnotetext{
${ }^{132}$ ALMEIDA, Guilherme Henrique de La Roque. Controle das transferências financeiras da União. Belo Horizonte: Fórum, 2008, p. 261.

${ }^{133}$ Op. Cit., p. 231.
} 
Medida Provisória $\mathrm{n}^{\circ}$. 595, de 6 de dezembro de 2012, convertida na Lei Federal $\mathrm{n}^{\circ}$. 12.815/2013, que dispõe sobre a exploração direta e indireta, pela União, de portos e instalações portuárias e sobre as atividades desempenhadas pelos operadores portuários.

Da Exposição de Motivos da referida Medida Provisória (EM Interministerial $\mathrm{n}^{\circ}$. 00012-A - SEP-PR/MF/MT/AGU) deriva toda a sistemática de exploração da atividade considerada estratégica para o país. Embasa na busca pela eficiência todas as alterações por ela implementadas, propondo modelo de estímulo à expansão dos investimentos do setor privado.

A própria lei trata de conceituar arrendamento: cessão onerosa de área e infraestrutura públicas localizadas dentro do porto organizado, para exploração por prazo determinado (art. $2^{\circ}$, inciso XI). $\mathrm{O}$ arrendamento só poderá ser firmado por pessoa jurídica que demonstre capacidade para seu desempenho, por sua conta e risco $\left(\operatorname{art} .1^{\circ}, \S\right.$ $\left.3^{\circ}\right)$.

São diretrizes deste modal contratual, dentre outras, a garantia da modicidade e publicidade das tarifas e preços praticados no setor (art. $3^{\circ}$, inciso II). Segue, portanto, que a remuneração do particular advirá desta fonte de recursos.

Para se formalizar o contrato deverá o interessado sagrar-se vencedor de processo licitatório, nos moldes do previsto na própria lei e seu regulamento (Decreto $\mathrm{n}^{\mathrm{o}}$. 8.033/2013). No contrato deverá constar, dentre outras cláusulas, as que tratam das tarifas praticadas e os critérios e procedimentos de sua revisão e reajuste. Seu prazo máximo será de 25 (vinte e cinco) anos, podendo ser prorrogado por, no máximo, igual período, uma única vez. É critério para julgamento da proposta a maior movimentação de carga com a menor tarifa. 
Frente a estas informações, o leitor poderá questionar qual a diferença entre o arrendamento e a concessão, também prevista na Lei Federal nº. 12.815/2013, considerando as similitudes (prazo, forma de remuneração, garantia de equilíbrio econômico-financeiro, etc).

Para nós, a diferença entre ambas as espécies contratuais, no contexto da referida legislação, reside no quantum do patrimônio público que será entregue ao particular, para execução e exploração da atividade de movimentação de cargas. No arrendamento, haverá a cessão de área dentro do porto organizado; na concessão a cessão é do porto organizado, e não de área dele.

Por fim, vale notar que a exploração de área do porto organizado ${ }^{134}$ se faz por conta e risco do arrendatário, devendo incorporar em sua tarifa todos os custos envolvidos na operação, considerando ser esta sua fonte primordial ou, quiçá, exclusiva de remuneração.

\subsection{CONTRATO DE FRANQUIA}

Outra modalidade contratual onde há a transferência da execução de atividade pública a particular é a franquia. Não há lei a disciplinando, quando uma das partes é a Administração Pública. Apesar de residir no direito privado todo seu regramento, não há motivo para se vetar seu uso pela Administração. Deixar de considerá-la possível nestes casos é fechar os olhos para a realidade. Hoje grande parte das agências dos correios são franqueadas da ECT (Empresa Brasileira de Correios e Telégrafos).

\footnotetext{
${ }^{134}$ Lei Federal no. 12.815/2013:

Art. $2^{\circ}$ Para os fins desta Lei, consideram-se:

I - porto organizado: bem público construído e aparelhado para atender a necessidades de navegação, de movimentação de passageiros ou de movimentação e armazenagem de mercadorias, e cujo tráfego e operações portuárias estejam sob jurisdição de autoridade portuária;
} 
No contrato de franquia, tal como nos contratos desta espécie firmados entre particulares, a franqueadora é quem impõe os critérios para a prestação do objeto delegado. Desde o layout do local até o uniforme dos funcionários é indicado pela franqueadora. Ao franqueado cabe o exercício da atividade dentro dos padrões estabelecidos por ela (Administração Pública).

Os contratos de franquia devem ter prazo suficiente para permitir ao particular amortizar os investimentos na adaptação da infraestrutura às exigências da franqueadora, bem como a obtenção de parcela de lucro que permita atraí-lo para o negócio. Talvez por isso alguns o entendam como uma concessão. Não o é por uma singela diferença: na concessão o particular estabelece o modus operandi na execução da atividade delegada; na franquia é a Administração quem ditará as regras e formas de prestação do serviço delegado.

Tratando da franquia na Administração Pública Cristiana Fortini ${ }^{135}$ assim se manifestou:

\begin{abstract}
A franquia é forma de modernizar a atuação da Administração Pública que se compatibiliza com a Constituição da República, ao refletir aplicação prática do princípio da eficiência. Sua utilização pode produzir resultados mais satisfatórios do que a celebração de contrato de concessão de serviços públicos, pacto do qual se aproxima.

Tanto na franquia quanto na concessão de serviços públicos, incidirá sobre terceiro o dever de executar a tarefa, assumindo os riscos do empreendimento, desonerando ainda a Administração Pública do emprego de recursos públicos em larga escala. À franqueadora, tal como ocorre com o Poder Concedente, competirá exercer o controle sobre os atos praticados pelo executor. Porém, impõe-se destacar que a franquia concentra nas mãos da Administração Pública maior controle do que o existente quando da celebração de concessão de serviço público. À franqueadora se reconhece o poder-dever de delimitar toda a atuação da franqueada - treinando seus empregados, indicando a forma como deve ser preparado o ambiente da empresa, fornecendo-lhe o know-how necessário para que o usuário usufrua o serviço nos mesmos moldes em que seria oferecido pela detentora da marca.
\end{abstract}

\footnotetext{
135 FORTINI, Cristiana. O princípio da legalidade e o emprego da franquia pela administração pública brasileira. In: Revista eletrônica de direito administrativo eletrônico. Salvador, Instituto de Direito Público da Bahia, no. 6, mai./jun./jul. de 2006. Disponível em: <www.direitodoestado.com/revista/REDAE-6-MAIO2006-CRISTIANA\%20FORTINI.pdf>. Acesso em 04 maio 2013.
} 
Na franquia há verdadeira transferência de atividade pública à execução por particular. E, pelo serviço prestado, deverá ser remunerado. Sua remuneração advém, de regra, da cobrança de tarifas dos usuários. Recentemente a ECT levou a efeito licitações para a escolha de pessoas jurídicas de direito privado interessadas em instalar e operar Agências de Correios Franqueadas - AGFs, unidades de atendimento destinadas à execução das atividades auxiliares relativas ao serviço postal. A vigência dos contratos de franquia postal resultantes dos certames é de $10(\mathrm{dez})$ anos, podendo ser prorrogados uma única vez, pelo mesmo período. A remuneração da franqueada se faz de parcela da tarifa paga pelo cliente quando da prestação dos serviços próprios da ECT.

\subsection{CONCESSÃO DE RADIODIFUSÃO}

Tomado o conceito de serviço público no seu viés mais amplo, a radiodifusão pode ser assim considerada, pois nada mais é do que uma comodidade colocada à disposição de uma universalidade de pessoas (usuários).

A prestação desse serviço pode se dar de forma direta (pela própria Administração Pública) ou através de seus delegados. O instrumento de delegação pode ser a concessão, a permissão ou a autorização, com as diferenças que lhe são peculiares. Vale dizer, contudo, que o uso deste serviço, quando colocado à disposição pela iniciativa privada, dá ensejo a um modal remuneratório um tanto quanto diferente, conforme restará demonstrado.

Para possibilitar a prestação deste serviço é necessária a utilização de um bem público. Assim, o uso do espectro de radiofrequências (bem público ${ }^{136}$ ) é delegado ao particular, para exploração, nos termos do art. 21, XI e XII, “a” da Constituição Federal.

${ }^{136}$ Lei Federal no $.9 .472 / 1997:$ 
Para ser concessionário/permissionário do serviço de radiodifusão sonoro e de sons e imagens outra condição deve ser atendida: a empresa que pretender explorar tal atividade deverá ser privativamente de brasileiros natos ou naturalizados há mais de dez anos, ou a pessoa jurídica deverá ser constituída sob as leis brasileiras e ter sede no País (art. 222, CF).

Ademais, a programação das emissoras de rádio e televisão deverá atender aos princípios insculpidos no art. 221 da Carta da República, o que demonstra a natureza do serviço (público).

Os serviços de radiodifusão são regulamentados pelo Decreto $\mathrm{n}^{\circ}$. 52.795/1963. Em seu art. $3^{\circ}$ constam as suas finalidades: educativa e cultural, mesmo em seus aspectos informativos e recreativos. Sua exploração comercial é permitida na medida em que não prejudique seus interesses e finalidades.

É notória a função social do rádio e da TV. O rádio é um dos veículos de comunicação mais dinâmicos da atualidade, mesmo nos tempos de internet, celulares e smartphones. Já a TV continua ganhando espaço na rotina recreativa das pessoas. Quantos não organizam seus afazeres de modo a estar em casa no horário da novela? O futebol do domingo à tarde ou mesmo o filme da madrugada, que distrai o acometido pela insônia!

Por essa razão a exploração deste serviço não é livre; em outras palavras, os detentores de concessões de radiodifusão não competirão livremente no mercado, senão dentro dos limites estabelecidos pelo Poder Concedente. Uma dessas limitações é a proibição da inclusão na programação de mais de $25 \%$ (vinte e cinco por cento) do horário diário de publicidade comercial (Decreto no. 52.795/1963, art. 28, 12, “d”).

Art. 157. O espectro de radiofrequência é um recurso limitado, constituindo-se em bem público, administrado pela Agência. 
Extrai-se deste preceito que a remuneração do concessionário de radiodifusão se faz através da exploração de espaços publicitários em sua programação. $\mathrm{O}$ usuário do serviço (ouvinte ou telespectador) nada pagará pela recepção dos sinais que, convertidos pelos aparelhos, darão ensejo à sua utilização. Os anunciantes são quem remuneram a concessionária, de acordo com os preços por ela praticados, diretamente atrelados à audiência de seus programas.

Desta forma, cabe à iniciativa privada, neste tipo de serviço, cumprindo os ditames do Poder Concedente, tornar sua grade de programação a mais interessante possível, atraindo a audiência e, por consequência, os anunciantes. Tratando das particularidades deste tipo de concessão, Maurício Castilho Machado ${ }^{137}$ fez constar:

\footnotetext{
Cumpre observar que, nem sempre os serviços públicos são remunerados mediante taxa ou tarifa. Podem ser citados como exemplos os serviços de radiodifusão sonora e de imagens, os quais não ensejam a cobrança nem de taxa, nem de tarifa. Nestes casos a remuneração se dá mediante preços privados, que são, em sua maioria, divulgação de mensagens publicitárias, e não são cobrados dos usuários, mas sim daqueles que tem interesse na propagação de suas mensagens.
}

\subsection{CONCESSÃO URBANÍSTICA}

O Estatuto da Cidade (Lei Federal no. 10.257/2001) prevê a atuação de particulares, em conjunto com a Administração, no processo de urbanização. Dentre as hipóteses de colaboração público/privado podemos citar a execução de planos de urbanização e renovação urbana, mediante contrato de concessão.

\footnotetext{
${ }^{137}$ MACHADO, Maurício Castilho. A tarifa nas concessões de serviço público. Jus Navigandi, Teresina, ano 14, $\mathrm{n}^{\circ} .2 .293,11$ out. 2009. Disponível em: 〈www.jus.com.br/revista/texto/13673〉. Acesso em 6 maio 2013.
} 
O Plano Diretor Estratégico do Município de São Paulo define a figura da concessão urbanística como a delegação, mediante licitação, a empresa ou consórcio de empresas, da realização de obras de urbanização ou reurbanização de região da cidade.

Visa a concessão urbanística a preservação dos recursos naturais, a proteção do patrimônio histórico, artístico, cultural e urbanístico, a racionalização do uso da infraestrutura instalada, em particular a do sistema viário e de transportes, evitando sua sobrecarga ou ociosidade, a recuperação de áreas degradadas ou deterioradas visando à melhoria do meio ambiente e das condições de habitabilidade, o estímulo à reestruturação e requalificação urbanística para melhor aproveitamento de áreas dotadas de infraestrutura, fomentando investimentos e revertendo o processo de esvaziamento populacional ou imobiliário.

Parece-nos razoável classificar o conjunto das atividades acima listadas como serviço público, não obstante reconhecer que sua consecução incluirá uma grande parcela de obras. Contudo, boa parte da doutrina não entende ser a concessão urbanística uma concessão de serviço público. Vejamos as lições de Karlin Olbertz ${ }^{138}$ :

\begin{abstract}
A concessão urbanística não se confunde com a concessão de serviço público ou com a concessão de obra pública. (...)

A primeira categorização é afastada porque a concessão urbanística volta-se expressamente à "realização de obras" e não à prestação de serviços públicos - provedores, para os fins do presente ensaio, de utilidades voltadas à satisfação de necessidades essenciais das pessoas. A segunda, porque a dita "realização de obras" envolve um conjunto de intervenções urbanísticas, e não a execução de uma obra específica.
\end{abstract}

Fazendo o contraponto à ideia acima exposta, Kleber Luiz Zanchim ${ }^{139}$ assim $^{2}$ fez constar:

\footnotetext{
138 OLBERTZ, Karlin. A regulamentação da concessão urbanística no Município de São Paulo. In: Informativo Justen, Pereira, Oliveira e Talamini. Curitiba, n. 25, mar. 2009. Disponível em: $\langle$ http://www.justen.com.br//informativo.php?I=pt\&informativo $=25 \&$ artigo $=878>$. Acesso em 09 novembro 2013.

139 ZANCHIM, Kleber Luiz. Concessão urbanística e serviço público. Disponível em: <http://www.migalhas.com.br/mig_amanhecidas.aspx?cod1=81406>. Acesso em 09 novembro 2013.
} 
Seria excesso de conservadorismo jurídico dizer que o fluido conceito de serviço público não abrange essas iniciativas da concessão urbanística. Claro que haverá obras nas regiões licitadas. Todavia, é preciso contextualizá-las em um todo maior representado por um processo de reformulação urbana repleto de atividades que não se resumem a construir.

Vale lembrar que as figuras jurídicas são delineadas por palavras e que as palavras estão em constante ajuste de sentido, conforme a evolução das necessidades da sociedade. Conceitos abertos como o de serviço público devem ser captados a partir da observação das mudanças sociais e econômicas. Agir de outra forma deslegitimaria o direito, tornando-o fonte de problemas ao invés de uma ferramenta de soluções. Concessão urbanística e serviços públicos são figuras compatíveis. Críticos, cuidado com as palavras...

Admitida como serviço público (e, por esta razão, incluída na presente tese - execução de atividade pública), resta saber como o particular executor de tal atividade irá se remunerar.

Uma das formas de remuneração do agente privado poderá derivar da exploração, por sua conta e risco, dos terrenos e edificações destinados a usos privados que resultarem das obras realizadas. Poderá também ser permitido que aufira renda da exploração de espaços públicos, nos termos fixados no edital de licitação e decorrente contrato.

Enfim, cada região alvo de concessão urbanística trará especificidades que permitirão, na elaboração do projeto, a extração de fontes de receitas capazes de atrair o particular à realização deste novel instrumento de política e intervenção urbana.

\subsection{PERMISSÃO}

As permissões de serviços públicos muito se assemelham às concessões de serviços públicos. Tratadas pela Lei Federal $n^{\circ}$. 8.987/1995, diferem em apenas alguns poucos aspectos, como bem aponta Alexandre Santos de Aragão ${ }^{140}$ :

${ }^{140}$ ARAGÃO, Alexandre Santos de. Direito dos serviços públicos. Rio de Janeiro: Forense, 2007, p. 719. 
As peculiaridades que esses dispositivos da Lei $\mathrm{n}^{\circ}$. 8.987/05 fixam para as permissões de serviços públicos em comparação com as concessões são as seguintes: (a) o permissionário pode ser pessoa física; $(b)$ não há referência expressa à necessidade de possuir prazo determinado; (c) não demandam necessariamente a modalidade licitatória da concorrência, devendo o procedimento cabível ser determinado nos termos da escala de valores do art. 23 da Lei $n^{\circ}$. 8.666/93; $(d)$ são qualificadas como contratos de adesão; $(e)$ são precárias e revogáveis unilateralmente; (f) não há previsão de permissões de obras públicas. (sic)

Ainda persiste na doutrina discussão acerca da natureza da permissão: se ato ou contrato administrativo. Parece assistir razão à parcela que a trata como contrato, pois por seu intermédio a Administração delega atividade à execução privada, sendo imperiosa a aceitação do encargo por parte de quem o recebe. A relação estabelecida entre Poder Público e particular, portanto, é de cooperação, típica dos vínculos contratuais.

Existem algumas permissões de serviços públicos onde a atividade delegada pressupõe a assunção, por parte do particular, de encargos financeiros bastante elevados. É o caso, dentre outros, do serviço de transporte rodoviário intermunicipal em alguns Estados da Federação. O permissionário deve adquirir veículos novos, manter garagens e estrutura operacional, no intuito de bem prestar o serviço a ele delegado. Nestes casos, estar-se-á diante de verdadeira concessão de serviço, pois é necessário um prazo de exploração da atividade para amortização do capital investido. Não se pode conceber permissão que demande investimento privado, sob pena de desnaturação do instituto.

Nesta esteira, cabem permissões às situações onde a Administração busca delegar atividade à execução privada sem a necessidade de aporte de recursos na implementação de infraestrutura (por esta razão não é possível a permissão de obras públicas). Tão logo decida retomar o serviço, o faz sem a necessidade de qualquer indenização, pois é da natureza da permissão sua precariedade.

Durante a execução do serviço objeto da permissão a forma tradicional de remuneração do permissionário é a cobrança de tarifa dos usuários da atividade por ele 
disponibilizada. Todas as particularidades das tarifas (tratadas no capítulo 5), referentes às concessões, se aplicam às permissões.

Por fim, vale lembrar que, diante de casos concretos, talvez sejam possíveis nas permissões outros modais remuneratórios, afora o tarifário. A natureza da atividade, por vezes, permitirá sejam extraídas utilidades capazes de gerar receitas mesmo em vínculos precários entre Estado e iniciativa privada.

\subsection{AUTORIZAÇÃO CONTRATUAL}

Além da concessão e da permissão, mediante a autorização a Administração também pode delegar a execução de atividades públicas a particulares. Tal conclusão se extrai da simples leitura do inciso XII do art. $21 \mathrm{da} \mathrm{CF}$.

Como visto no item acima, a diferenciação entre concessão e permissão de serviço público não é tarefa das mais singelas. O que dizer então da distinção entre estas e a autorização. Vejamos:

Para Alexandre Santos de Aragão ${ }^{141}$, as "autorizações de serviços públicos", na realidade, são concessões ou permissões. Não existe, em sua doutrina, espaço para atuação privada em atividade pública mediante delegação via autorização. Neste sentido:

Quando leis que regulam setores de serviços públicos se referem à autorização administrativa pode haver duas circunstâncias: ou a atividade em questão integra o setor, mas não é serviço público (ex.: serviços de telefonia móvel, auto-geração de energia), e a autorização será então um ato de poder de polícia; ou, caso verse realmente sobre serviço público, recebendo inclusive uma estrutura contratual em razão da titularidade estatal da atividade, estaremos materialmente

${ }^{141}$ Op. Cit., p. 727. 
diante não de uma autorização, mas sim de uma delegação de serviço público (concessão caso haja bens reversíveis, e, caso não os haja, em princípio permissão - cf. tópico anterior). Teremos, portanto, uma autorização em sentido apenas nominal; teremos uma "autorização" contratual.

Parece assistir razão ao ilustre publicista, quando se está a tratar de delegação de serviço público. Contudo, algumas atividades públicas (que não diretamente relacionadas a serviços públicos) podem ser entregues à execução privada por meio da autorização. Vejamos o magistério de Odete Medauar ${ }^{142}$ :

Quanto à autorização, permanece sua formalização por ato administrativo discricionário e precário. Em geral, pela autorização se transfere ao particular serviços de fácil execução, de regra sem remuneração por tarifas - é o caso da autorização para conservação de praças, jardins ou canteiros de avenidas, em troca da afixação de placa com o nome da empresa. A autorização de serviço não é objeto da Lei 8.987/95.

Nestes termos, a delegação de atividade ou de uso de bem pode se dar via autorização, que difere das concessões e permissões por não decorrer de contrato, mas sim de ato administrativo.

Com relação à remuneração do particular nas autorizações (tema de interesse do presente estudo), pode se dar de diversas formas, a depender da natureza da atividade. Já nos deparamos, certa feita, com autorização para que todo e qualquer proprietário de "van" realizasse o transporte de munícipes à cidade vizinha, até o restabelecimento de ponte que havia se rompido, considerando que os ônibus da concessionária do serviço regular de transporte não podiam trafegar pela estrada vicinal, pois seus pequenos viadutos não suportariam o peso do coletivo. Neste caso, a remuneração se dava através da cobrança de tarifa dos usuários do serviço, no mesmo preço do praticado pela concessionária do serviço regular.

${ }^{142}$ Op. Cit., p. 327. 
De outra maneira se dá a remuneração no caso de autorização para conservação de praças e jardins, como no exemplo dado pela Profa. Odete Medauar, acima colacionado. Nesta hipótese a remuneração do particular advém da exposição de sua marca, mediante afixação de placa com nome e logotipo da empresa. Não existe remuneração direta, mas sim uma contrapartida da Administração pela atividade executada.

Tal como nos exemplos citados, o que deve haver, no que tange à remuneração do particular que executa atividade pública mediante autorização, é uma correlação proporcional entre encargos assumidos pelo particular e retorno financeiro obtido do negócio. Não seria legítima a atuação privada na conservação de pequena praça tendo como contrapartida o direito de nela instalar grande letreiro luminoso com seus logotipos. Nem seria adequada a assunção da obrigação de manutenção e conservação do Parque Ibirapuera pelo particular autorizado a apor, em suas poucas lixeiras, pequena menção de seu nome. 


\section{SISTEMA "S" - SERVIÇOS SOCIAIS AUTÔNOMOS}

Os Serviços Sociais Autônomos, conhecidos popularmente como integrantes do Sistema "S", são criados após autorização legislativa e vêm, atualmente, ganhando espaço como prestadores de atividades de interesse público a categorias profissionais específicas. Consta do sítio eletrônico do Governo Federal ("Portal Brasil") ${ }^{143}$ :

O aperfeiçoamento profissional é uma modalidade de ensino que prepara as pessoas para o mundo do trabalho. Ele serve para atualizar ou complementar os conhecimentos que o trabalhador já possui.

Para ajudar na qualificação e na formação profissional de seus empregados, os empresários têm no Sistema S um forte aliado. Formado por organizações criadas pelos setores produtivos (indústria, comércio, agricultura, transportes e cooperativas), as entidades oferecem cursos gratuitos em áreas importantes da indústria e comércio.

O Sistema S conta com uma rede de escolas, laboratórios e centros tecnológicos espalhados por todo o território nacional. Também há ofertas de cursos pagos, geralmente com preços mais acessíveis do que oferecidos por instituições particulares de ensino.

$\overline{143}$ <www.brasil.gov.br/empreendedor/capacitacao/sistema-s>. Acesso em 07 maio 2013. 
Qualificar e promover o bem-estar social e disponibilizar uma boa educação profissional é a finalidade do Sistema S, que conta com 11 instituições, entre elas o Sebrae (Serviço Brasileiro de Apoio às Micro e Pequenas Empresas), que dá orientações sobre como abrir e gerenciar uma empresa e contratar funcionários.

As instituições que compõem o Sistema $\mathrm{S}$ prestam diversas atividades, visando sempre a melhoria da qualidade de vida do trabalhador e de seus dependentes, especialmente por meio de ações em educação, saúde e lazer ${ }^{144}$. Tais atividades são de reconhecido interesse público, permitindo concluir atuarem nesses setores por outorga dessa competência pela própria lei que autoriza sua criação.

Todavia, suas naturezas são de pessoas jurídicas de direito privado ${ }^{145}$, não integrando a Administração Pública Indireta. São criadas por Confederações privadas, em nada dependendo do Poder Público para atuar.

144 - SENAI (Serviço Nacional de Aprendizagem Industrial) - a quem cabe a educação profissional e aprendizagem industrial, além da prestação de serviços de assistência técnica e tecnológica às empresas industriais.

- $\quad$ SESI (Serviço Social da Indústria) - promove a melhoria da qualidade de vida do trabalhador e de seus dependentes por meio de ações em educação, saúde e lazer.

- $\quad$ IEL (Instituto Euvaldo Lodi) - capacitação empresarial e do apoio à pesquisa e à inovação tecnológica para o desenvolvimento da indústria.

As três instituições acima são subordinadas à Confederação Nacional da Indústria. Além dessas, outras organizações do Sistema S são:

- $\quad$ SENAC (Serviço Nacional de Aprendizagem Comercial) - educação profissional para trabalhadores do setor de comércio e serviços.

- $\quad$ SESC (Serviço Social do Comércio) - promoção da qualidade de vida dos trabalhadores do setor de comércio e serviços.

- $\quad$ SENAR (Serviço Nacional de Aprendizagem Rural) - educação profissional para trabalhadores rurais.

- $\quad$ SENAT (Serviço Nacional de Aprendizagem em Transportes) - educação profissional para trabalhadores do setor de transportes.

- $\quad$ SEST (Serviço Social de Transportes) - promoção da qualidade de vida dos trabalhadores do setor dos transportes.

- $\quad$ SESCOOP (Serviço Nacional de Aprendizagem do Cooperativismo) - aprimoramento e desenvolvimento das cooperativas e capacitação profissional dos cooperados para exercerem funções técnicas e administrativas.

145 Nos autos do AI 349.477-AgR/PR, o Exmo. Min. Celso de Mello, analisando questão processual (prerrogativa da Fazenda Pública de prazo em dobro para recorrer), assim se manifestou:

"Cabe assinalar, por necessário, que a parte ora agravante constitui ente de cooperação, possuindo a natureza de serviço social autônomo, revestido de paraestatalidade e qualificando-se, por isso mesmo, como pessoa jurídica de direito privado, o que significa que não se lhe estende a prerrogativa excepcional inscrita no art. 188 do CPC". (sem ênfase no original) 
Como executoras de atividades públicas, portanto, precisam ser remuneradas, sob pena de se colocar em risco o próprio serviço prestado. Neste sentido, válidas as lições de Rafael Carvalho Rezende Oliveira ${ }^{146}$ :

Tais entidades, uma vez constituídas, entre outras receitas, receberão "dinheiro público" (contribuições sociais), cobrado compulsoriamente da iniciativa privada, conforme previsão do art. 240 da CRFB, e serão submetidas ao controle estatal.

Destaque-se que essas contribuições parafiscais são de instituição exclusiva da União (art. 149 da CRFB), mas isso não impede a constituição de Serviços Sociais pelos Estados, DF e municípios, que seriam custeados de outras formas.

As contribuições sociais compõem a principal fonte de remuneração dessas instituições. Por fim, vale lembrar que, por receberem dinheiro público, se sujeitam aos órgãos de controle:

Decreto-Lei $n^{\circ}$. 200/1967:

Art. 183. As entidades e organizações em geral, dotadas de personalidade jurídica de direito privado, que recebem contribuições parafiscais e prestam serviços de interesse público ou social, estão sujeitas à fiscalização do Estado nos termos e condições estabelecidas na legislação pertinente a cada uma.

\footnotetext{
${ }^{146}$ OLIVEIRA, Rafael Carvalho Rezende. Administração pública, concessões e terceiro setor. 2. Ed. Rio de Janeiro: Lumen Juris, 2011, p. 301.
} 


\section{A CONTRATAÇÃO DE PRESTADOR DE SERVIÇO}

10.1. O fenômeno da terceirização.

Como titular dos serviços públicos, cabe à Administração prestá-los ou promover sua prestação com o auxílio de terceiros. Tratamos nos capítulos precedentes da prestação de serviços públicos por particular, que recebeu essa incumbência por delegação de competência do Poder Público.

A gestão dos serviços públicos pode ser dividida em três funções: estratégica, operacional e material. A função estratégica atine à competência de criar ou suprimir a atividade, escolher seu prestador (caso a opção seja delegar a sua execução), determinar os princípios de seu funcionamento e fiscalizar sua prestação. 
Já a função operacional está intimamente ligada ao modo de funcionamento do serviço: logística da atividade, implementação de metas, relacionamento com o usuário, definição do quantum necessário à completa execução da atividade.

Finalmente, a função material, que é a execução efetiva da atividade, constitui-se nas tarefas do mundo material tendentes a dar concretude ao serviço idealizado pela função estratégica e delineado pela função operacional.

A função estratégica é indelegável, dependendo sempre de atos de autoridade para ser válida, visto tratar de competência afeta à esfera de poderes políticos (política pública), carecedores de legitimidade popular. Já a função operacional é delegável (remetemo-nos ao capítulo 2 da presente tese). A função material, por sua vez, é delegável e/ou realizável através da contratação de locação de serviços.

Nas concessões/permissões de serviços públicos a Administração delega as funções operacional e material à execução privada. Todavia, é possível a Administração permanecer com as funções estratégica e operacional, contratando apenas a execução da função material, através de uma espécie de contratação conhecida por "terceirização".

\subsection{O FENÔMENO DA TERCEIRIZAÇÃO}

A terceirização nada mais é do que espécie contratual de locação de serviços. Disciplinada pela Lei Federal $n^{\circ}$. 8.666/1993, é uma das formas pela qual o Estado firma parcerias com o setor privado, na busca da satisfação do interesse público. 
Não pode o Poder Público, neste tipo de contratação, visar obter mão de obra, sob pena de burlar a regra do concurso público. O que é permitido é a contratação de pessoal para prestação de serviço, nos termos do art. $6^{\circ}$, inciso II da Lei Federal $n^{\circ}$. 8.666/1993. O Decreto $n^{\circ}$. 2.271/1997 dispõe sobre a contratação de serviços pela Administração:

\begin{abstract}
Decreto $\mathrm{n}^{\circ} .2 .271 / 1997$ :
Art. $1^{\circ}$ No âmbito da Administração Pública Federal direta, autárquica e fundacional poderão ser objeto de execução indireta as atividades materiais acessórias, instrumentais ou complementares aos assuntos que constituem área de competência legal do órgão ou entidade. $\S 1^{\circ}$ As atividades de conservação, limpeza, segurança, vigilância, transportes, informática, copeiragem, recepção, reprografia, telecomunicações e manutenção de prédios, equipamentos e instalações serão, de preferência, objeto de execução indireta.
\end{abstract}

Da leitura do dispositivo acima transcrito percebe-se ser indicada a execução indireta das atividades listadas. Isto porque, caso realizadas por servidores, certamente seriam mais custosas aos cofres públicos e, ousamos dizer, não atingiriam os mesmos níveis de qualidade da execução privada.

Como salienta Patrícia Pinheiro Silva ${ }^{147}$, “ o serviço objeto de terceirização é uma tarefa prestada pelo particular imediatamente à Administração para satisfação dos interesses desta em apoio ao exercício de suas atribuições.” Essa é a regra. Todavia, várias são as situações nas quais o particular contratado para prestar serviços acaba por realizar sua atividade diretamente ao seu usuário final, sem que a Administração participe dessa relação, senão apenas como coadjuvante.

Assim, por vezes o particular "terceirizado" estará executando atividade pública ao administrado, e não à Administração, como é o caso da empresa que realiza exames de raio-X nos hospitais de um município. Está prestando uma atividade acessória à principal (saúde), mas naquela ocasião executou um serviço diretamente ao usuário

${ }^{147}$ SILVA, Patrícia Pinheiro. Terceirização nos serviços públicos. In: Revista do Tribunal Superior do Trabalho, v. 77, n. 1, jan./mar. 2011. Disponível em:

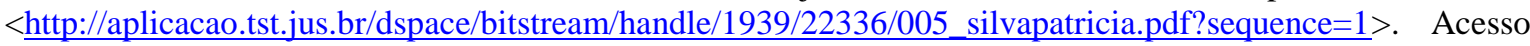
em 09 maio 2013. 
(paciente), sem a intervenção do Estado. $\mathrm{O}$ segurança que permanece à porta da Faculdade Pública é funcionário de uma empresa terceirizada, prestando serviços à Universidade (com relação à segurança do patrimônio público) e aos seus alunos (que são os usuários finais do serviço).

A remuneração na terceirização também difere da remuneração tradicional do particular executor de atividade pública (concessões). Nesta, a regra é a cobrança de tarifa dos usuários. Naquela, a remuneração é inteiramente paga pelo Poder Público. Pode o contrato prever o pagamento por lapsos pré-fixados (usualmente mensal), ou por medições do trabalho efetivamente prestado (quantidade de exames de raio-X realizados, por exemplo). O valor dos serviços deriva da proposta comercial apresentada pela empresa por ocasião do processo licitatório que culminou com sua contratação ${ }^{148}$. Aplicável aqui o princípio da necessária manutenção do equilíbrio econômico-financeiro do contrato. Outrossim, deve o contrato trazer formas de reajuste dos valores (normalmente atrelados a um índice de correção monetária, com aplicação anual).

Por força do disposto no inciso II do art. 57 da Lei Federal nº ${ }^{\circ}$ 8.666/1993, a duração máxima dos contratos de prestação de serviços é de 60 (sessenta) meses. Vale ainda ressaltar que a temática das terceirizações tangencia o direito do trabalho, cumprindo observar, mesmo nas contratações desta natureza envolvendo a Administração Pública, a Súmula $n^{\circ}$. 331 do Tribunal Superior do Trabalho ${ }^{149}$. Neste sentido as lições de Maria Sylvia Zanella Di Pietro ${ }^{150}$ :

\footnotetext{
${ }^{148} \mathrm{O}$ instituto do credenciamento também pode ser utilizado nas hipóteses aventadas. Difere apenas com relação à remuneração do prestador do serviço. Neste modelo contratual os particulares não apresentam propostas comerciais, mas aderem à "tabela de referência", já fixada pela Administração.

${ }_{149}$ Súmula n'. 331 do TST:

CONTRATO DE PRESTAÇÃO DE SERVIÇOS. LEGALIDADE.

$(\ldots)$

$\mathrm{V}$ - Os entes integrantes da Administração Pública direta e indireta respondem subsidiariamente, nas mesmas condições do item IV, caso evidenciada a sua conduta culposa no cumprimento das obrigações da Lei $\mathrm{n}^{\circ}$. 8.666, de 21.06.1993, especialmente na fiscalização do cumprimento das obrigações contratuais e legais da prestadora de serviço como empregadora. A aludida responsabilidade não decorre de mero inadimplemento das obrigações trabalhistas assumidas pela empresa regularmente contratada.

${ }^{150}$ Op. Cit., p. 344.
} 
Cada vez que a Administração Pública recorre a terceiros para a execução de tarefas que ela mesma pode executar, ela está terceirizando.

Embora se trate de contratação que obedece às regras e princípios do direito administrativo, a terceirização acaba, muitas vezes, por implicar burla aos direitos sociais do trabalhador da empresa prestadora do serviço, o que coloca a Administração Pública sob a égide do direito do trabalho. Daí a necessidade de sujeitar-se às decisões normativas da Justiça do Trabalho. 


\section{PARTICULARES \\ COLABORAÇÃO COM O PODER PÚBLICO}

11.1. Notários e registradores; 11.2. Leiloeiros;

11.3. Tradutores e intérpretes públicos.

Há ainda um grupo de particulares, executores de atividade pública, cuja remuneração é recebida de forma um pouco diversa. Os particulares em colaboração com o poder público, não obstante exercerem função pública, não detém vínculo empregatício com o Estado. Vejamos as lições de Maria Sylvia Zanella Di Pietro ${ }^{151}$ :

Nesta categoria entram as pessoas físicas que prestam serviços ao Estado, sem vínculo empregatício, com ou sem remuneração. Podem fazê-lo sob títulos diversos, que compreendem:

1. delegação do Poder Público, como se dá com os empregados das empresas concessionárias e permissionárias de serviços públicos, os que exercem serviços notariais e de registro (art. 236 da Constituição), os leiloeiros, tradutores e intérpretes públicos; eles exercem função pública, em seu próprio nome, sem vínculo empregatício, porém sob

${ }^{151}$ Op. Cit., p. 516. 
fiscalização do Poder Público. A remuneração que recebem não é paga pelos cofres públicos mas pelos terceiros usuários do serviço;

Estaremos a tratar, neste capítulo, dos seguintes particulares que colaboram com a Administração Pública: notários e registradores; leiloeiros e; tradutores e intérpretes públicos.

\title{
11.1. NOTÁRIOS E REGISTRADORES
}

Vejamos o que dispõe a Constituição Federal:

\begin{abstract}
Constituição Federal:
Art. 236. Os serviços notariais e de registro são exercidos em caráter privado, por delegação do Poder Público.

$\S 1^{\circ}$ Lei regulará as atividades, disciplinará a responsabilidade civil e criminal dos notários, dos oficiais de registro e de seus prepostos, e definirá a fiscalização de seus atos pelo Poder Judiciário.

$\S 2^{\circ}$ Lei federal estabelecerá normas gerais para fixação de emolumentos relativos aos atos praticados pelos serviços notariais e de registro.

$\S 3^{\circ} \mathrm{O}$ ingresso na atividade notarial e de registro depende de concurso público de provas e títulos, não se permitindo que qualquer serventia fique vaga, sem abertura de concurso de provimento ou de remoção, por mais de seis meses.
\end{abstract}

Do comando constitucional acima transcrito se verifica que os serviços notariais e de registro são atividades públicas delegadas à execução privada. Luís Paulo Aliende Ribeiro ${ }^{152}$ consignou:

\begin{abstract}
A imposição do regime privado de execução, vedada expressamente a atuação estatal direta, caracteriza o exercício privado de função pública e acrescenta um dado a mais para a demonstração de que a atividade notarial e de registros apresenta peculiaridades que a diferenciam de quaisquer outras, singularidade que emerge do estudo mais detalhado dessas profissões oficiais ou profissões públicas independentes.
\end{abstract}

\footnotetext{
${ }^{152}$ RIBEIRO, Luís Paulo Aliende. A regulação da função pública notarial e de registro. Tese de Doutorado. Faculdade de Direito da Universidade de São Paulo, 2008, p. 49.
} 
O exercício necessariamente privado ocorre no campo destinado à gestão privada, ou seja, na atuação jurídica dos notários e registadores e no gerenciamento financeiro e de pessoal de cada unidade de serviço, o que, quanto à organização geral dos serviços e à relação de sujeição especial que liga os delegados ao Poder Público outorgante, não afasta o regime jurídico de direito público e a natureza estatal desta singular atividade de atribuição da fá pública e da publicidade oficial a atos, contratos e direitos de terceiros.

Desta forma, estes agentes estarão atuando em nome próprio, sob a tutela do

Estado.

A lei que regulamenta o art. 236 da Carta da República (Lei Federal nº. 8.935/1994) estabelece a forma de atuação destes agentes. Vale trazer à baila, entretanto, a forma pela qual serão remunerados.

Os atos notariais e de registro não são remunerados pelos cofres públicos, mas sim pelo recolhimento de custas e emolumentos pelos usuários de tais serviços. Coube à Lei Federal $n^{\circ}$. 10.169/2000 tratar das normas gerais de fixação dos emolumentos relativos aos atos praticados pelos serviços notariais e de registro.

Emolumentos, nesta esteira, podem ser entendidos como a obrigação pecuniária a ser paga pelo requerente do serviço notarial ou de registro. Nas lições de Regnoberto Marques de Melo Jr. ${ }^{153}$ :

Em suma: o emolumento do notário e do registrador traduz-se, portanto, em obrigação de valor nominal, em dívida de dinheiro, nascente de relação jurídica obrigacional de fazer, em que figura, como sujeito passivo, o particular delegado de serviço notarial e registral, obrigado a prestar esses serviços públicos ao usuário, credor, numa relação de direito privado contratual, sob o regime do CDC.

(...)

A natureza jurídica do emolumento notarial e registral reveste-se, portanto, de essência privatística, funcionando como uma contraprestação remuneratória, salarial, de propriedade do notário e registrador, e que tem como fim o cometimento dos seus misteres públicos e sociais.

${ }^{153}$ MELO JR., Regnoberto Marques de. Da natureza jurídica dos emolumentos notariais e registrais. Jus Navigandi, Teresina, ano 10, n. 591, 19 fev. 2005. Disponível em: 〈http://jus.com.br/revista/texto/6313 > Acesso em 18 julho 2013. 
Não se trata, portanto, de taxa, como insiste em considerar o Supremo Tribunal Federal (dentre outros: ADI 2653-MT, ADI 2123-ES; em sentido contrário: ADinMC 1752-RJ). Cabe aos Estados e ao Distrito Federal a fixação dos seus valores, devendo corresponder ao efetivo custo e à adequada e suficiente remuneração dos serviços prestados (art. $2^{\circ}$, Lei Federal no $.10 .169 / 2000$ ).

\subsection{LEILOEIROS}

A atividade desempenhada pelos leiloeiros é disciplinada pelo Decreto $\mathrm{n}^{\circ}$. 21.981/1932. Em suma, lhes compete a venda, em hasta pública ou público pregão, de bens de qualquer natureza (o Decreto os especifica: imóveis, móveis, mercadorias, utensílios, semoventes e mais efeitos), por ordem de seus donos, ou por alvará judicial.

Ao assim agirem, estarão atuando com fé de oficiais públicos. Serão mandatários do proprietário do bem ou do juízo que lhes nomeou. Por isso, devem exercer pessoalmente suas funções. $\mathrm{O}$ decreto regulamentar da atividade traz a disciplina acerca dos requisitos para se tornar um leiloeiro (art. $2^{\circ}$ ). Estão sujeitos à prestação de fiança $\mathrm{e}$ termo de compromisso, e são nomeados pelas Juntas Comerciais dos Estados. Sendo assim, atuam por delegação do Poder Público, sendo ilícito o exercício da função por quem não estiver regularmente habilitado:

Decreto $\mathrm{n}^{\circ} .21 .981 / 1932$ :

Art. $8^{\circ} \mathrm{O}$ leiloeiro só poderá entrar no exercício da profissão, depois de aprovada a fiança oferecida e de ter assinado o respectivo compromisso perante à Junta comercial.

Sua remuneração se dá por intermédio da cobrança de comissão, normalmente atrelada ao valor do bem a ser alienado: 
Decreto $n^{\circ}$. 21.981/1932:

Art. 40. O contrato que se estabelece entre o leiloeiro e a pessoa, ou autoridade judicial, que autorizar a sua intervenção ou efetuar a sua nomeação para realizar leilões, é de mandato ou comissão e dá ao leiloeiro o direito de cobrar judicialmente a sua comissão e as quantias que tiver desembolsado com anúncios, guarda e conservação do que lhe for entregue para vender, instruindo a ação com os documentos comprobatórios dos pagamentos que houver efetuado, por conta dos comitentes e podendo reter em seu poder algum objeto, que pertença ao devedor, até o seu efetivo embolso.

Quando não há estipulação prévia da comissão, esta será de 5\% (cinco por cento) sobre móveis, semoventes, mercadorias, jóias e outros efeitos e de 3\% (três por cento) sobre bens imóveis de qualquer natureza (art. 24). O devedor da comissão é o arrematante do bem:

Código de Processo Civil:

Art. 705. Cumpre ao leiloeiro:

(...)

IV - receber do arrematante a comissão estabelecida em lei ou arbitrada pelo juiz;

Vale lembrar que atualmente o uso da tecnologia vem ganhando espaço neste ramo de negócio. Plataformas eletrônicas são utilizadas para criar um ambiente virtual de oferecimento de lances, autorizados a todos os previamente cadastrados, até prédeterminado dia e horário. O leiloeiro será o responsável pela regularidade do procedimento, respondendo por qualquer fraude eventualmente detectada.

\subsection{TRADUTORES E INTÉRPRETES PÚBLICOS}

A tradução juramentada é aquela feita por quem tem fé pública, refletindo, em português, o que efetivamente consta do original. Só é válida se realizada por tradutor juramentado (ou tradutor público, como também são denominados estes profissionais). Para tanto, os interessados em exercer tal ofício precisam estar habilitados perante as Juntas Comerciais dos Estados. 
Sua nomeação se dá através da aprovação em concurso de provas; todavia, não será o tradutor público um servidor público, apesar de se sujeitar a uma regulação específica, ditada pela Junta Comercial do Estado a que é vinculado. Atuará como profissional autônomo, sendo pessoal seu ofício (suas funções não podem ser delegadas, sob pena de nulidade dos atos praticados pelo substituto e perda do ofício).

A atividade está regulamentada pelo Decreto $\mathrm{n}^{\circ}$. 13.609/1943. Tratando da remuneração desses profissionais:

Decreto ${ }^{\circ}$. 13.609/1943:

Art. 29. As Juntas Comerciais ou órgãos correspondentes organizarão as tabelas de emolumentos devidos aos tradutores, independentemente das custas que lhes possam caber como auxiliares dos trabalhos da Justiça, bem como estipularão os que devem ser pagos pelos respectivos candidatos aos examinadores dos concursos, submetendo êsse ato à aprovação do Govêrno do Estado ou a do Ministro de Estado do Trabalho, Indústria e Comércio, conforme o caso. O Presidente e o Secretário da Comissão examinadora não terão direito a remuneração alguma. (sic)

Os emolumentos serão, portanto, fixados pelas Juntas Comerciais, tomando por base a lauda de vinte e cinco linhas datilografadas ou mil caracteres, sem espaços. No Estado de São Paulo, por exemplo, os valores variam de acordo com a natureza do documento: texto comum (passaportes, certidões dos registros civis, etc., desde que não envolvam textos jurídicos, técnicos ou científicos) ou texto especial (jurídicos, técnicos, científicos, comerciais, inclusive bancários e contábeis, certificados e diplomas escolares). Ademais, à tradução é estabelecido um valor menor do que para a versão ${ }^{154}$.

Em suma: trata-se de atividade pública delegada à execução privada. $\mathrm{O}$ particular será sempre pessoa física, habilitada a exercer suas funções após aprovação em concurso, remunerando-se através da cobrança de emolumentos. A demanda por seus préstimos é incerta, dependente da procura por eventuais interessados.

\footnotetext{
${ }^{154}$ Tradução é a operação que consiste em fazer passar um enunciado emitido numa língua estrangeira para o equivalente na língua local. Já a versão é o processo inverso.
} 


\title{
12.ATIVIDADE: EXPLORAÇÃO DIRETA DE ATIVIDADE ECONÔMICA PELO ESTADO
}

\author{
12.1. Capitalismo como base do modelo \\ econômico; 12.2. Requisitos para atuação do \\ particular neste mister; 12.3. Particular como \\ agente de execução da atividade pública; 12.4 . \\ A necessária busca pelo lucro.
}

Como já apontado no capítulo 1, item 1.3, é tipo de atividade administrativa a exploração direta de atividade econômica pelo Estado. A Administração, ao assim agir, está dando cumprimento a uma de suas funções, qual seja, a de intervir no mercado, ferindo, à primeira vista, a regra geral do sistema capitalista (livre concorrência), amparada por preceitos autorizadores que conduzem à ideia de atendimento ao interesse público.

Vale lembrar ter essa "intervenção" previsão constitucional, restando autorizada desde que atendidas algumas condições, como adiante restará demonstrado. Em 
regra, não é legítima a atuação empresarial do Estado em mercados onde impera a "concorrência perfeita". Trata-se de conceito da ciência econômica, assim explicitado por Emerson Santiago ${ }^{155}$ :

\begin{abstract}
$\mathrm{Na}$ economia, tanto nacional como mundial, em praticamente todos os setores, temos muitas firmas atuando no meio industrial e muitos consumidores atuando com efeitos indiretos uns frente aos outros. É nesse contexto que é considerada a existência do fenômeno "concorrência perfeita", onde encontramos uma situação limite em que nenhuma empresa ou nenhum consumidor detém o poder suficiente de influenciar o preço de mercado. As firmas produtoras, juntamente com os indivíduos consumidores são os responsáveis por determinar no ambiente de mercado a quantidade e o preço a serem seguidos por todas as firmas do setor econômico, em um fluxo natural de oferta e procura em meio à relação entre os participantes.
\end{abstract}

O cenário acima delineado, de um mercado com muitos compradores e muitos vendedores, no qual ninguém influi sobre os preços das mercadorias, é utópico. Talvez seja possível visualizar setores econômicos onde a concorrência perfeita exista - e, nestes setores, não estará o Estado autorizado a atuar. Estaria então sua atuação empresarial restrita aos mercados onde imperam a "concorrência imperfeita" (não existe homogeneidade - mercado compartimentado), o "oligopólio" (pequeno número de empresas que controlam a oferta e o mercado - poucos vendedores, muitos compradores) ou o "monopólio" (apenas um vendedor, que define o preço).

A atuação estatal direta no mercado, quando efetuada fora desses contextos econômicos, não encontra amparo no sistema capitalista e, por consequência, fere a Constituição Federal.

\title{
12.1. CAPITALISMO COMO BASE DO MODELO ECONÔMICO
}

\footnotetext{
155 SANTIAGO, Emerson. Concorrência perfeita. InfoEscola - Economia. Disponível em:
} <http://www.infoescola.com/economia/concorrencia-perfeita/>. Acesso em 10 maio 2013. 
O modelo econômico brasileiro é, historicamente, baseado no sistema capitalista. A livre iniciativa e a livre concorrência são princípios que nortearam o constituinte de 1988, construindo um ambiente onde o Estado pouco ou nada intervém no mercado, senão em situações bastante específicas. É essa garantia de pouca intervenção que fez do Brasil um destino seguro de investimentos privados. Hoje a economia nacional se sobressai no cenário mundial devido ao respeito ao texto constitucional, retratado pelas sólidas instituições da nação. O capitalismo, desta forma, é o grande propulsor do desenvolvimento econômico e do progresso social, da forma como hoje a humanidade os idealiza.

Caso a intervenção no mercado fosse indefinidamente permitida, estaríamos diante de uma afronta constitucional, não só pelo descumprimento imediato do art. 173 da $\mathrm{CF}$, mas igualmente pelo desrespeito ao preceito econômico nela estampado. São inúmeros os aspectos do capitalismo previstos na nossa constituição: livre iniciativa, livre concorrência, direito de propriedade, liberdade de trabalho, ofício ou profissão, dentre outros. O seu Título VII (Da Ordem Econômica e Financeira) consagra a valorização do trabalho, da livre iniciativa, a justiça social, a defesa do consumidor e do meio ambiente, etc. A regra, portanto, é a da geração de renda pela atividade privada. Tratando do assunto Marçal Justen Filho ${ }^{156}$ bem observou:

\footnotetext{
A Constituição consagrou um regime capitalista, fundado nos princípios da livre iniciativa e da livre concorrência. Os serviços públicos são excluídos do âmbito desses princípios.

Se o Estado pudesse assumir o desempenho direto das atividades econômicas propriamente ditas e a elas aplicar privilégios e benefícios, estaria destruída a distinção básica. Então, todas as atividades poderiam ser transformadas em serviço público, inclusive aquelas destituídas de cunho essencial.

Assim não é, uma vez que não se admite que o Estado qualifique como serviço público atividade não vinculada diretamente aos direitos fundamentais. Não pode fazê-lo nem mesmo por via do expediente de atribuir a si próprio benefícios no exercício de certa atividade econômica.

(...)

A solução constitucional brasileira não deixa margem de dúvida. Somente em situações excepcionais o Estado desempenhará atividade econômica propriamente dita. E, quando o fizer, será inconstitucional criar qualquer privilégio em seu próprio benefício.
}

${ }^{156}$ Op. Cit., pp. 807/808. 
Das lições acima transcritas dessume-se ser incomum a atuação estatal direta no mercado, autorizada em alguns poucos casos, desde que atendidos os requisitos constitucionais e sem o oferecimento de nenhuma vantagem. Cabe ao Estado, antes de intervir no domínio econômico, buscar alternativas à sua intervenção. O fomento é uma forma de se evitar tal atuação.

\subsection{REQUISITOS PARA ATUAÇÃO DO PARTICULAR NESTE MISTER}

O texto constitucional é claro ao permitir a exploração direta de atividade econômica pelo Estado quando ${ }^{157}$ : i) necessária aos imperativos da segurança nacional, e/ou; ii) necessária ao atingimento de relevante interesse coletivo. O caput do art. 173 da Carta da República dispõe que tais condições serão definidas em lei.

Contudo, até a presente data o legislador infraconstitucional não produziu a lei que traria concretude ao comando constitucional. Percebe-se, portanto, serem as hipóteses de incidência dessa prerrogativa do Estado definidas por conceitos jurídicos indeterminados ${ }^{158}$ (o que é relevante interesse coletivo?). Isso dificulta a prática desta atividade, bem como o controle desta atuação.

Não obstante considerarmos bastante fluído o conceito de "segurança nacional”, o Supremo Tribunal Federal, na vigência de outro texto constitucional, teve a oportunidade de apreciar a matéria:

RE 62730/SP - São Paulo RECURSO EXTRAORDINÁRIO

\footnotetext{
${ }^{157}$ Sendo monopólios da União, a atuação do Estado nas atividades previstas nos incisos do art. 177 da CF não só é permitida como esperada.

${ }^{158}$ Estar-se-á diante de um conceito jurídico indeterminado quando a sua vaguidade semântica não permita ao intérprete chegar a resultado objetivo na sua intelecção.
} 
Relator(a): Min. ALIOMAR BALEEIRO

Julgamento: 23/08/1967

Ementa

1. A APRECIAÇÃO DOS CASOS DE "URGENCIA" OU DE "INTERESSE PÚBLICO RELEVANTE”, A QUE SE REFERE O ARTIGO 58, DA CONSTITUIÇÃO DE 1967, ASSUME CARÁTER POLÍTICO E ESTA ENTRE AO DISCRICIONARISMO DOS JUIZES DE OPORTUNIDADE OU DE VALOR DO PRESIDENTE DA REPUBLICA, RESSALVADA APRECIAÇÃO CONTRARIA E TAMBÉM DISCRICIONARIA DO CONGRESSO. 2. MAS O CONCEITO DE "SEGURANÇA NACIONAL" NÃO É INDEFINIDO OU VAGO, NEM ABERTO ÀQUELE DISCRICIONARISMO DO PRESIDENTE OU DO CONGRESSO. "SEGURANÇA NACIONAL" ENVOLVE TODA A MATÉRIA PERTINENTE À DEFESA DA INTEGRIDADE DO TERRITÓRIO, INDEPENDÊNCIA, SOBREVIVENCIA E PAZ DO PAÍS, SUAS INSTITUIÇÕES E VALORES MATERIAIS OU MORAIS CONTRA AMEAÇAS EXTERNAS E INTERNAS, SEJAM ELAS ATUAIS E IMEDIATAS OU AINDA EM ESTADO POTENCIAL PRÓXIMO OU REMOTO. 3. REPUGNA A CONSTITUIÇÃO QUE, NESSE CONCEITO DE “SEGURANÇA NACIONAL”, SEJA INCLUIDO ASSUNTO MIUDO DE DIREITO PRIVADO, QUE APENAS JOGA COM INTERESSES TAMBÉM MIUDOS E PRIVADOS DE PARTICULARES, COMO A PURGAÇÃO DA MORA NAS LOCAÇÕES CONTRATADAS COM NEGOCIANTES COMO LOCATÁRIOS. (grifamos)

Com o devido respeito à Suprema Corte, continuamos a considerar o conceito de "segurança nacional" algo não palpável, senão frente ao caso concreto. Haverá hipóteses onde restará claramente autorizada a atuação empresarial do Estado: em casos de guerra declarada o Estado se põe a fabricar aviões para uso militar (zona de certeza positiva). Não restaria tão claro o atendimento ao preceito constitucional caso o Estado fabricasse aviões militares em situação de paz (zona de penumbra). Por fim, a fabricação de aviões comerciais certamente não estaria enquadrada na hipótese "imperativos da segurança nacional”, fosse guerra ou paz (zona de certeza negativa).

Face ao acima exposto, enquanto não houver lei que determine, de forma objetiva, quais hipóteses configuram a atuação estatal em atendimento a imperativos de segurança nacional, apenas a situação concreta dirá se é, ou não, caso de sua aplicação. Uma única constatação, em tese, é possível: apenas à União é permitido atuar em nome da segurança nacional. Tal competência é exclusiva dela, não cabendo aos Estados, Distritos ou Municípios agirem neste sentido. 
A fluidez do conceito também acomete o "interesse coletivo relevante". Na prática da atuação estatal nesta seara de atribuições é muito mais comum vê-las embasadas nesta hipótese do que na segurança nacional. Marçal Justen Filho ${ }^{159}$ assim o identificou:

O interesse coletivo consiste na existência de uma necessidade supraindividual, comum a um número relevante de pessoas, cuja satisfação possa ser proporcionada pela atuação direta do Estado.

Ressalta o autor que o interesse coletivo a ser satisfeito pela atuação estatal deve ser significativo, pois, em regra, qualquer atividade econômica pode satisfazê-lo. Em prol do interesse coletivo relevante não só a União, mas também os Estados, Distrito Federal e Municípios podem explorar atividade econômica.

Vale lembrar, por fim, que em qualquer das hipóteses as empresas estatais criadas com o fim de atuar diretamente no mercado estarão sujeitas parcialmente ao regime de direito público. Em outras palavras, são passíveis de averiguação pelos órgãos de controle, bem como submetidas à obrigação de licitar (salvo para contratações relacionadas a atividades-fim da empresa) e de promover concurso público. Neste sentido são as lições de José Eduardo Martins Cardozo ${ }^{160}$ :

Já o segundo argumento se prende à regra firmada no artigo 173 , parágrafo $1^{\circ}$, da mesma Carta Constitucional. Segundo este dispositivo a empresa pública, a sociedade de economia mista e outras entidades que explorem a atividade econômica em nome do Poder Público "sujeitam-se ao regime jurídico próprio das empresas privadas, inclusive quanto as obrigações trabalhistas e tributárias". Com efeito, este dispositivo determina que empresas públicas e sociedades de economia mista que exploram atividade econômica exerçam suas atividades em situação equivalente às empresas privadas em geral, isto é, dentro do mesmo regime jurídico destas.

Claro, pois, que a nossa lei maior comanda que tais empresas estatais não possam atuar com vantagens ou com ônus jurídicos em relação às empresas privadas. E de tal constatação podem decorrer as seguintes indagações: não seria a exigência do concurso público um ônus a colocar estas empresas em desigualdade com a iniciativa privada? Não seria esta imposição uma descaracterização do regime jurídico próprio das empresas privadas, e por conseguinte, uma desfiguração do artigo 173 , parágrafo $1^{\circ}$, da Constituição Federal? Não seria correto dizer-se então que, em boa interpretação sistemática, as empresas estatais que exploram atividade

\footnotetext{
${ }^{159}$ Op. Cit., p. 813.

${ }^{160}$ CARDOZO, José Eduardo Martins. As empresas públicas e as sociedades de economia mista e o dever de realizar concursos públicos no direito brasileiro. Jus Navigandi, Teresina, ano 2, n. 17, 10 ago. 1997. Disponível em: <www.jus.com.br/revista/texto/386. Acesso em 14 maio 2013.
} 
econômica deveriam ser liberadas do ônus de contratar seus empregados por via de concurso público?

Não nos parece. O fato do caput do artigo 37 não ter feito a distinção entre empresas que exploram atividade econômica de outras (ou seja, as prestadoras de serviços), não autoriza qualquer interpretação que não fosse amparada em uma sólida lógica sistemática oposta. E tal, a bem da verdade, não ocorre.

\subsection{PARTICULAR COMO AGENTE DE EXECUÇÃO DA ATIVIDADE PÚBLICA}

O Estado, ao explorar diretamente atividade econômica, deverá fazê-lo por intermédio de empresa pública ou sociedade de economia mista, nos termos do $\S 1^{\circ}$ do art. 173 da CF. Como ressalta Odete Medauar ${ }^{161}$, as chamadas estatais (aí incluídas as empresas públicas, as sociedades de economia mista e as empresas controladas direta ou indiretamente pelo Poder Público) foram sendo criadas "de modo mais acentuado nas décadas de 60 e 70, como forma de participação direta do Estado na atividade econômica".

Façamos a distinção de empresas públicas e sociedades de economia mista, utilizando-se da doutrina de Marçal Justen Filho ${ }^{162}$ :

\footnotetext{
- Empresa pública é uma pessoa jurídica de direito privado, dotada de forma societária, cujo capital é de titularidade de uma ou mais pessoas de direito público e cujo objeto social é a exploração de atividade econômica ou a prestação de serviço público ou de serviços de apoio ao próprio Estado.

- Sociedade de economia mista é uma sociedade anônima sujeita a regime diferenciado, sob controle de entidade estatal, cujo objeto é a exploração de atividade econômica ou prestação de serviço público.
}

Nota-se ter a empresa pública, em sua formação, capital oriundo exclusivamente da Administração (mesmo que de mais de uma pessoa de direito público). Já a sociedade de economia mista tem seu patrimônio composto majoritariamente pela participação estatal, mas não exclusivamente. É possível a existência de sociedade de

\footnotetext{
${ }^{161}$ Op. Cit., p. 86.

162 Op. Cit., pp. 261/263.
} 
economia mista só com capital público; entretanto, é permitida a participação da iniciativa privada.

Nesta esteira, por óbvio que apenas as sociedades de economia mista poderão representar, em última instância, a execução de atividade pública pelo particular. $\mathrm{Na}$ realidade, a execução da atividade pública (no caso, a intervenção no domínio econômico) é feita pela estatal. Todavia, este agente de mercado tem na sua composição capital privado.

Decorre do texto constitucional serem as sociedades de economia mista constituídas sob a modalidade de sociedade anônima. Parte acionária da empresa poderá estar nas mãos de particulares, investidores que buscam na atuação da estatal um retorno financeiro ao capital investido. A atividade comercial explorada só se faz possível com o aporte de recursos privados. Nestes casos, não há como negar ter o particular, ao menos em parte, executado atividade pública, intervindo no domínio econômico. E assim o fez por uma razão econômica: visando o lucro.

\subsection{A NECESSÁRIA BUSCA PELO LUCRO}

Nos moldes do acima exposto, é de se concluir que as sociedades de economia mista (que tenham como objetivo intervir diretamente no domínio econômico, principalmente quanto tiverem na composição de seu capital recursos da iniciativa privada) são agentes capitalistas em busca do lucro. Sua modalidade (sociedade anônima) assim determina, pois a própria participação acionária é um instrumento de especulação. A ação é um valor mobiliário, negociável sem dependência dos demais acionistas. 
A quem não concorda com o posicionamento acima firmado, questionamos: qual o interesse do particular em participar de uma sociedade cujo objetivo seja algo diferente do lucro?

A matéria já foi alvo de análise pelo Supremo Tribunal Federal, que analisou a aplicabilidade do regime de precatórios às sociedades de economia mista exploradoras de atividade econômica. No caso, a Eletronorte (Centrais Elétricas do Norte do Brasil S.A.) pretendia ver seus débitos judiciais executados por meio de precatório, o que não foi acolhido pela Corte Suprema (vencidos os ministros Ayres Britto, Dias Toffoli e Gilmar Mendes). Deste Recurso Extraordinário (RE 599.628) alguns trechos merecem destaque:

Recurso Extraordinário 599.628 Distrito Federal

O Senhor Ministro JOAQUIM BARBOSA

(...)

Também relevante é circunstância de a concorrente ser sociedade de economia mista, voltada à exploração lucrativa em benefício de seus acionistas, sejam eles entidades públicas ou privadas.

(...)

De fato, o exercício de atividade com intuito lucrativo, sem monopólio estatal, deve submeterse aos instrumentos de garantia do equilíbrio concorrencial, nos termos do art. $173, \S 1^{\circ}$, II e $\S$ $2^{\circ}$ da Constituição. Em especial, a empresa pública e a sociedade de economia mista devem despir-se das prerrogativas própria do Estado nas hipóteses em que incursionarem na seara de exploração econômica. (sic)

\begin{abstract}
A Senhora Ministra ELLEN GRACIE
(...)

A recorrida bem destacou que a Eletronorte tem participado, em igualdade de condições, dos leilões relativos à geração e transmissão de energia elétrica promovidos pela ANEEL, inclusive em consórcio com empresas privadas. Isso já demonstra, suficientemente, que se trata de empresa que desenvolve atividade econômica, sim, em ambiente competitivo aberto à iniciativa privada.
\end{abstract}

\title{
O Senhor Ministro RICARDO LEWANDOWSKI
}

(...)

Eu tenho aqui um quadro, que é muito revelador, da composição acionária da Eletronorte. Inicialmente eu verifico que se trata de uma empresa jurídica de direito privado que se submete ao regime próprio das empresas privadas, nos termos do artigo $173, \S 1^{\circ}$, da Constituição Federal. Ela atua no regime de livre concorrência e visa ao lucro.

Interessantemente, parte do capital social da Eletronorte é de propriedade da Eletrobrás, sendo o restante detido por particulares.

(...) 
Outro aspecto que me chama a atenção é que o estatuto da Eletronorte, em seu artigo 36, prevê inclusive a distribuição de lucros a seus empregados. Portanto, é uma empresa privada que visa ao lucro, que inclusive distribui esse lucro, ou há pelo menos previsão de distribuição do lucro, aos seus empregados.

Nota-se ser o lucro a finalidade da atuação empresarial destas sociedades. Por esta razão, e não por outra, que o particular direciona recursos e participa de sua composição. Fechar os olhos para esta realidade é perder de vista a racionalidade do sistema capitalista.

O fato é que, por vezes, a Administração Pública controladora da sociedade de economia mista se "esquece" dessa finalidade precípua e resolve utilizá-la como instrumento de atuação estatal, visando a promoção de políticas públicas, em detrimento do lucro. Fere, desta forma, direito legítimo dos acionistas privados, que só injetaram recursos na empresa (em última instância, executora de atividade pública - intervenção no domínio econômico) para ganhar dinheiro.

Age desta forma o Banco do Brasil (sociedade de economia mista que explora atividade econômica) ao baixar as taxas de juros em suas linhas de crédito para patamares muito abaixo dos praticados pelos demais players deste mercado, com a clara intenção de alavancar a economia nacional com uma maior oferta de crédito, mesmo em desrespeito ao ideal lucro (pois o ganho com o empréstimo desse capital estará aquém do potencial extraível em situação de normalidade competitiva). Faz-se, portanto, política pública com o "chapéu alheio""163.

\footnotetext{
${ }^{163}$ Tal prática é comum no Brasil, especialmente nos serviços públicos. O Estado concede sua prestação, determinando seja o particular remunerado através da cobrança de tarifas. No curso da concessão, contudo, estabelece gratuidades das mais diversas naturezas. No transporte público tal realidade é clara: diminui a idade para consideração da qualidade de idoso (que viaja sem nada pagar), inclui categorias profissionais que serão gratuitamente transportadas (policiais, bombeiros militares, oficiais de justiça).

Vale também trazer a lume as recentes e contundentes manifestações que, em poucos dias, tomaram conta de diversas cidades do Brasil (e de algumas de outros países onde há uma expressiva quantidade de brasileiros residentes) em prol da redução das tarifas do transporte coletivo municipal. Todas as Administrações Municipais que sofreram os influxos destes atos de repúdio público cederam à pressão imposta pelos populares, reduzindo as tarifas aos patamares anteriores, em prejuízo dos prestadores do serviço e em total desrespeito às cláusulas contratuais que previam o reajuste praticado.
} 


\title{
13.ATIVIDADE: EXECUÇÃO DE ELEMENTOS DO PODER DE POLÍ́CIA
}

\author{
13.1. O poder de polícia como competência; \\ 13.2. Elementos; 13.3. Execução por particular; \\ 13.4. Formas de remuneração.
}

Conforme demonstrado no capítulo 1 do presente trabalho (item 1.3.), é função típica da Administração Pública o exercício do poder de polícia. No capítulo 2 restou consignado que parcelas dessa função podem ser delegadas à execução por particulares. Resta saber, nesta oportunidade, como se manifesta tal atividade, do que é composta, quais partes podem ser delegadas e como o agente privado será remunerado pela atividade desempenhada. 
Parece-nos pacífico o entendimento: poder de polícia é atividade da Administração Pública. A ela a Constituição Federal reservou a missão de defender a ordem pública. Para cumprir tal desiderato, acode ao administrador uma infinidade de ações que, reunidas, representam o efetivo exercício do poder de polícia.

Tais ações são de diversas naturezas (normativas e administrativas). Contudo, tomadas em conjunto, expressam uma competência da Administração, consubstanciadas no poder de polícia. Neste sentido são as lições de Marçal Justen Filho $^{164}$ :

O poder de polícia administrativa é a competência para disciplinar o exercício da autonomia privada para a realização de direitos fundamentais e da democracia, segundo os princípios da legalidade e da proporcionalidade.

Em acepção ampla, o poder de polícia compreende competências legislativas e administrativas. Alude-se a poder de polícia administrativa para indicar o conjunto de competências desenvolvidas pela autoridade estatal em nível infralegal, mediante providências destinadas a dar concretude a valores, princípios e regras consagrados em normas constitucionais e legais.

(sem ênfase no original)

Celso Antônio Bandeira de Mello ${ }^{165}$ assim conceitua competência:

Visto que o "poder" expressado nas competências não é senão a face reversa do dever de bem satisfazer interesses públicos, a competência pode ser conceituada como o círculo compreensivo de um plexo de deveres públicos a serem satisfeitos mediante o exercício de correlatos e demarcados poderes instrumentais, legalmente conferidos para a satisfação de interesses públicos.

Percebe-se, portanto, que os poderes instrumentais exercidos pela Administração, tendentes à concreção do poder de polícia, na realidade é o exercício de competências a ela inerentes.

\footnotetext{
${ }^{164}$ Op. Cit., p. 553.

165 Op. Cit., p. 140.
} 


\subsection{ELEMENTOS}

Em estudo específico sobre o poder de polícia (já referido no presente trabalho - v. nota de rodapé $n^{\circ}$. 30) observamos ser o mesmo composto de vários atos:

(...) na maioria das vezes, o meio pelo qual o poder de polícia é exercido pela Administração não se exaure na prática de um único singelo ato. Pelo contrário, algumas situações se completam após a consecução de uma série de pequenos atos. Vejamos: o direito de fiscalizar uma dada atividade aflora à Administração por decorrência de lei que preveja tal atuação. Desta previsão legal a estrutura administrativa é manejada no sentido de verificar se, por exemplo, um restaurante está em condições de receber o público. Diversas exigências técnicas de segurança e higiene serão verificadas. A validade dos gêneros alimentícios será alvo de avaliação. O exercício do poder de polícia, no caso, estará completo com a constatação de regularidade ou não - de atendimento ou não dos requisitos pré-estabelecidos. Na hipótese acima podemos destacar, de início, 3 "atos" que compõem o manejo do poder em comento: 1) previsão legal; 2) verificação material da regularidade; 3) aplicação de sanção.

Por ocasião do julgamento do Recurso Especial $\mathrm{n}^{\circ}$. 817.534 - MG (2006/0025288-1), o Exmo. Ministro Mauro Campbell Marques, relator do processo, concluiu: "as atividades que envolvem a consecução do poder de polícia podem ser sumariamente divididas em quatro grupos, a saber: (i) legislação; (ii) consentimento; (iii) físcalização e (iv) sanção" ${ }^{166}$.

Nem todo ato de polícia apresenta, em sua composição, os 4 elementos acima elencados. Existem atos de polícia de formação mais singela, exemplo: retirada de vendedores ambulantes das vias públicas. Percebe-se, neste caso, não ter existido o elemento "consentimento". Mesmo assim, não deixa de ser ato de polícia, pois "disciplina e restringe, em favor do interesse público adequado, direitos e liberdades individuais" (TÁCITO, Caio. O poder de polícia e seus limites. Direito administrativo. 1975. apud

\footnotetext{
166 Consta do próprio acórdão exemplificação da separação sugerida pelo I. Ministro: "No âmbito da limitação do exercício da propriedade e da liberdade no trânsito, esses grupos ficam bem definidos: o CTB estabelece normas genéricas e abstratas para a obtenção da Carteira Nacional de Habilitação (legislação); a emissão da carteira corporifica a vontade do Poder Público (consentimento); a Administração instala equipamentos eletrônicos para verificar se há respeito à velocidade estabelecida em lei (fiscalização); e também a Administração sanciona aquele que não guarda observância ao CTB (sanção)". (grifamos)
} 
MEDAUAR, Odete. Direito administrativo moderno. 12. Ed. São Paulo: RT, 2008, p. 333).

Desta forma, não obstante a completude do poder de polícia abranger 4 (quatro) elementos, não se descaracteriza na ausência de um deles. A "legislação" é o único elemento obrigatoriamente presente na sua construção, pois sem ele a atuação administrativa não encontra respaldo (princípio da legalidade). Resta saber quais dos elementos podem ser objeto de delegação à execução por particular.

\subsection{EXECUÇÃO POR PARTICULAR}

No início do presente trabalho destacamos a possibilidade de delegação de alguns dos elementos que compõem o poder de polícia. Naquela oportunidade afirmamos ser apenas a legislação indelegável, pois carece de legitimidade democrática. Neste capítulo defenderemos a delegabilidade dos demais elementos: consentimento, fiscalização e sanção.

Alguns desses elementos são praticados de forma vinculada - ou seja, não exigem do seu executor qualquer tipo de decisão. Por essa razão podemos afirmar serem delegáveis os atos jurídicos de polícia inteiramente vinculados, pois seriam praticados da mesma forma se o fossem pelos agentes da Administração ou da empresa delegatária da atividade. Nesta hipótese (de total vinculação) podemos incluir a parcela do consentimento e da fiscalização. É nesses elementos que reside o motivo ${ }^{167}$ do ato administrativo. E, a nosso ver, o motivo é essencial à atuação estatal, visto ser exigível à sua validade, especialmente nos atos restritivos de direitos. Percebe-se, portanto, ser a delegação dessa

\footnotetext{
${ }^{167}$ Nas lições de Odete Medauar, "motivo significa as circunstâncias de fato e os elementos de direito que provocam e precedem a edição do ato administrativo". (MEDAUAR, Odete. Direito administrativo moderno. 12. Ed. São Paulo: RT, 2008, p. 137).
} 
parcela do poder de polícia, na realidade, a entrega do poder de construir o ato, pois seus elementos mais importantes serão realizados pelo particular.

A mesma simplicidade de raciocínio não se aplica aos atos de polícia discricionários. E, neste particular, reside o elemento sanção. Poderia uma empresa de direito privado aplicar multa a infratores de uma norma jurídica, por exemplo? A questão foi objeto de análise do Poder Judiciário, ao discutir a possibilidade da BHTrans, sociedade de economia mista (pessoa jurídica de direito privado, portanto), gerenciar o trânsito da capital mineira, aplicando multa aos infratores. Segue trecho do V. Acórdão da lavra do Exmo. Sr. Des. Edilson Fernandes, proferido nos autos do processo no ${ }^{\circ}$ 3530351-942004.8.13.0024 - Tribunal de Justiça do Estado de Minas Gerais - julgado aos 26/04/2005:

Portanto, não se vislumbra óbice à delegação do Poder de Polícia Estatal para entidades que apesar da sua forma de constituição (sociedade de economia mista - f. 156/159), exercem atividade nitidamente pública, extraindo-se então, o seu interesse social, notadamente, quanto aos serviços ali desempenhados.

(...)

Por sua vez, as limitações administrativas à liberdade e à propriedade são o que muitos denominam "poder de polícia", assim consideradas as atividades que restringem, na forma da lei, por meio de imposições, deveres ou abstenções, o exercício de direitos individuais, a fim de se evitar comportamentos danosos ao seio social. Compreendem, portanto, a elaboração de atos preventivos ou repressivos, como a fiscalização e imposição de sanções.

(...)

Ora, sendo o poder de polícia inerente à Administração Pública e recebendo o agente de trânsito delegação da autoridade competente para agir dentro dos limites da jurisdição do município, extrai-se que este possui o poder-dever de aplicar as multas cabíveis ao ato infracional em concreto, sob pena de sua atuação, ao final, revelar-se inócua.

(sem ênfase no original)

Qual seria a eficácia do poder de polícia não fosse o receio da sanção? Sem ela de nada adiantaria a delegação da fiscalização. A fiscalização implica em poderes para quem a executa de sancionar os infratores de tal ou qual comando normativo. Portanto, apesar de não encontrar amparo na jurisprudência do Superior Tribunal de Justiça (que no julgamento do Recurso Especial nº 817.534 - MG entendeu ser indelegável o elemento sanção), ousamos defender ser delegável tal esfera de atuação estatal. 
Em resumo: parece-nos válida a divisão do poder de polícia em quatro elementos, mesmo nem sempre concomitantemente presentes. Destes elementos, todos são delegáveis, exceto a legislação, núcleo indelegável do poder de polícia, face à necessária legitimidade democrática e rito procedimental para que se tome como válida.

\subsection{FORMAS DE REMUNERAÇÃO}

Em cada tipo de atividade uma fonte de receita pode ser aventada, visando a remuneração daquele que irá executá-la. Não é diferente no exercício do poder de polícia, nas suas parcelas delegáveis. As diversas situações nas quais tal atividade estatal se faz presente nos permite afirmar serem infinitas as formas de remuneração, cabendo ao idealizador do "projeto" de delegação vislumbrar as possíveis alternativas e escolher a que melhor atenda ao interesse público. Vejamos alguns exemplos:

1) Autuação e imposição de multas pelo sistema de radar eletrônico e fotográfico.

Em diversas cidades do país a Municipalidade delegou a fiscalização do trânsito a empresas, ficando estas encarregadas de fazer a constatação da infração às normas de trânsito por intermédio de equipamentos por ela instalados, para posterior imposição de multas.

A remuneração do delegatário, em grande parte dos contratos, está atrelada à sua produtividade; em outras palavras, ganha por infração registrada. Assim se remunera o particular prestador desta atividade pública. O contrato traz um valor a ser pago por auto de infração gerado pelo particular. Tal sistemática remuneratória foi alvo de uma série de ações judiciais atacando sua legalidade. Seguem alguns julgados nos quais foi discutida a possibilidade de delegação deste poder de polícia e o modal remuneratório do executor de tal atividade: 
Superior Tribunal de Justiça

REsp 772347/DF

ADMINISTRATIVO. RECURSO ESPECIAL, OMISSÃO NÃO CONFIGURADA. INEXISTÊNCIA DE VIOLAÇÃO AO ARTIGO 535, II DO CPC. MULTA DE TRÂNSITO. NULIDADE DE AUTOS DE INFRAÇÃO. EQUIPAMENTO ELETRÔNICO (RADAR FIXO) LAVRATURA DO AUTO DE INFRAÇÃO. AUSÊNCIA DE INDICAÇÃO DO AGENTE AUTUADOR. ART. 280 DO CTB. RESOLUÇÃO DO CONTRAN.

(...)

3. O Código de Trânsito Brasileiro e Resoluções do CONTRAN permitem a comprovação de infrações no trânsito por meio de aparelhos eletrônicos.

(...)

5. Os "pardais" não aplicam multas, apenas fornecem elementos fáticos para que o DETRAN lavre o auto e imponha sanções quando comprovadas as infrações.

Superior Tribunal de Justiça

Recurso Especial no. 712.312/DF

ADMINISTRATIVO. RECURSO ESPECIAL. MULTA DE TRÂNSITO. NECESSIDADE DE IDENTIFICAÇÃO DO AGENTE. AUTO DE INFRAÇÃO.

(...)

2. "Daí não se segue, entretanto, que certos atos materiais que precedem atos jurídicos de polícia não possam ser praticados por particulares, mediante delegaçãoo, propriamente dita, ou em decorrência de um simples contrato de prestação. Em ambos os casos (isto é, com ou sem delegação), às vezes, tal figura aparecerá sob o rótulo de "credenciamento"".

(grifamos)

Tribunal de Justiça do Estado de São Paulo

Apelação Cível nº. 261.849-5/7

(..)

2 - Legítima a instalação, por empresa particular vencedora de licitação, de radares controladores de velocidade de veículos com vistas à constatação visual de infrações de trânsito.

(..)

Por outro lado, a remuneração constante dos contratos realizados (" $R \$ 32,40 \ldots$ para cada Auto de Infração/Notificação ... emitido com base em prova visual gerada por equipamento fornecido pela CONTRATADA, desde que reconhecido como válido pela JARI") encontrase em harmonia com a previsão do edital ("Prevê-se o pagamento à Contratada, a cada mês, um valor unitário por Auto de Infração/Notificação ... emitido com base em prova visual gerada por equipamento ...”), representando sua estipulação em critério objetivo para o equilíbrio contratual, não ofensivo à moralidade administrativa.

(sem ênfase no original)

2) Autuação e imposição de multas por estacionamento de veículo em desacordo com as condições regulamentares de sinalização.

O trânsito nas médias e grandes cidades do Brasil está cada dia pior. Políticas econômicas praticadas nas últimas décadas favoreceram a aquisição de veículos, 
hoje financiáveis em infindáveis parcelas, permitindo a estratos menos favorecidos da população o acesso a um automóvel.

Este contexto singelamente exposto tem levado os municípios a concederem a gestão do espaço público, implantando a mais comumente denominada "zona azul", determinando regiões da cidade onde o estacionamento de veículos será pago e limitado, democratizando o uso das vagas e diminuindo o fluxo de carros principalmente na área central da cidade.

Nestas concessões é comum ficar a fiscalização do sistema "área azul” a cargo da concessionária. Sua remuneração advém da cobrança de tarifas dos usuários, estando nela incorporados os custos desta atividade típica de polícia: a constatação do uso inadequado do serviço. A delegação deste elemento do poder de polícia também foi alvo de uma infinidade de ações. Seguem alguns casos:

Tribuna de Justiça do Estado de Santa Catarina

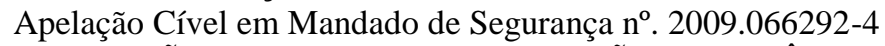

ANULAÇÃO DE AUTOS DE INFRAÇÃO DE TRÂNSITO. IMPOSIÇÃO DE MULTAS POR ESTACIONAMENTO DE VEÍCULO EM DESACORDO COM AS CONDIÇÕES REGULAMENTARES DE SINALIZAÇÃO. ESTACIONAMENTO ROTATIVO. ZONA AZUL.

(...)

3) NOTIFICAÇ̃̃O REALIZADA POR MONITORES DE ENTIDADE PRIVADA. AUTOS DE INFRAÇÃ̃O LAVRADOS POR AUTORIDADE POLICIAL. POSSIBILIDADE. RECURSO DESPROVIDO.

(..)

Com base nessas normas, monitores do CDL (Clube de Diretores Lojistas) são incumbidos de verificar a utilização adequada do sistema, e, em caso de irregularidade, cientificam o usuário informando-o de que dispõe do prazo de 5 (cinco) dias úteis para efetuar o pagamento de taxa correspondente a $10(\mathrm{dez})$ vezes o valor da hora normal, sob pena de autuação por infração de Trânsito pelo órgão competente, na forma e para os fins do artigo 181, inciso XVII, do Código de Trânsito.

(...)

O curial é alinhavar que o Convênio $\mathrm{n}^{\circ}$. 050/2003, celebrado entre o Município de Brusque e o CDL, acha-se autoriza pela legislação municipal pertinente, sendo o instrumento jurídico adequado para a delegação das competências previstas no Código de Trânsito Brasileiro, dentre as quais se encontra a fiscalização das áreas de estacionamento rotativo. (sic) 
Tribunal de Justiça do Estado de Santa Catarina

Apelação Cível no. 2007.000662-5

(...)

LAVRATURA DE AVISO DE IRREGULARIDADE POR PREPOSTO DA CONCESSIONÁRIA DE SERVIÇO PÚBLICO. POSSIBILIDADE.

(...)

É que, em se tratando de concessionária de serviço público, pressupõe-se que haja fé-pública no documento lavrado pelo preposto, a fim de que possa a autoridade policial apreciar e lavrar, ou não, o auto de infração. Mister salientar que quem lavra o auto de infração é a autoridade policial e não o funcionário da permissionária. $O$ aviso de recebimento apenas fornece elementos fáticos que permitem à autoridade de trânsito uma apreciação do ocorrido, a possível lavratura do auto de infração e a imposição de sanções, quando necessário.

3) O exercício de poder de polícia pelo Operador Nacional do Sistema Elétrico (ONS).

O Operador Nacional do Sistema Elétrico (ONS) “é o órgão responsável pela coordenação e controle da operação das instalações de geração e transmissão de energia elétrica no Sistema Interligado Nacional (SIN), sob a fiscalização e regulação da Agência Nacional de Energia Elétrica (Aneel). O ONS é uma pessoa jurídica de direito privado, sob a forma de associação civil, sem fins lucrativos." 168

Dentre os objetivos e atribuições do ONS podemos destacar:

- a supervisão e a coordenação dos centros de operação de sistemas elétricos, a supervisão e o controle da operação do SIN e das interligações internacionais;

- a proposição de regras para a operação das instalações da transmissão da Rede Básica do SIN, mediante processo público e transparente.

Os membros associados devem respeitar as regras, cumprindo os Procedimentos de Rede e da legislação setorial aplicável à operação do SIN (art. 11 do Estatuto). Percebe-se estar o ONS, no exercício de suas funções, executando atividades inerentes ao poder de polícia (supervisão, etc.). Como acima salientado, trata-se de pessoa

${ }^{168}$ Informações extraídas do sítio eletrônico: 〈www.ons.org.br〉. Acesso em 21 maio 2013. 
jurídica de direito privado, a gerir toda a operação do sistema eletroenergético do país, visando a racionalidade do sistema.

A remuneração do ONS, nos termos do art. 34 de seu Estatuto, advém de: i) contribuições de seus membros associados, proporcional ao número de votos na Assembleia-Geral, incluídas na Parcela "A" para fins de repasse tarifário e as recolhidas por outros associados e agentes do setor elétrico que não estão sujeitas a repasse tarifário; ii) recursos decorrentes do orçamento elaborado pelo ONS e aprovado pela Aneel, repassados pelos associados e agentes do setor elétrico conectados à Rede Básica, cujos valores são incluídos na Tarifa de Uso do Sistema de Transmissão - TUST e na Parcela "A" das tarifas do serviço de energia elétrica e recolhidos por outros associados e agentes do setor elétrico que não estão sujeitos a repasse tarifário, bem como outras eventuais receitas autorizadas pela Aneel. Apesar de se tratar de associação civil sem fins lucrativos, de rigor seja sua atuação remunerada, sob pena de se colocar em risco a própria atividade.

4) A novel legislação de portos e instalações portuárias - Lei Federal no $12.815 / 2013$

A referida legislação busca regular a exploração pela União, direta ou indiretamente, dos portos e instalações portuárias, e as atividades desempenhadas pelos operadores portuários.

Consta que cabe à administração do porto organizado, denominada autoridade portuária, dentre outras funções, fiscalizar a operação portuária, suspender operações portuárias, estabelecer o horário de funcionamento do porto, etc.. Haverá um Conselho de Autoridade Portuária (CAP), que não passa de um órgão de natureza administrativa, incumbido de regulamentar sua exploração, supervisionar sua operação e planejar sua produção qualitativa e quantitativa. Esse conselho será composto por representantes do poder público, dos operadores portuários, dos trabalhadores portuários e dos usuários dos serviços portuários e afins. 
Parece-nos que este Conselho estará exercendo, no cumprimento de suas atribuições, típico poder de polícia. Apesar do texto da lei tratar o CAP como órgão consultivo da administração do porto, determina que o seu regulamento disporá sobre suas atribuições e funcionamento. A própria exploração do porto, através da cobrança de tarifas, irá remunerar a atividade do Conselho (e dos seus membros), importando em típico exercício de poder de polícia. 


\title{
14.NOVAS FORMAS DE REMUNERAÇÃO
}

\author{
14.1. Recursos advindos das garantias nas \\ parcerias público-privadas; 14.2. A expectativa \\ de receita futura; 14.3. Gestão de capital; 14.4. \\ Potencial econômico gerado pela construção da \\ infraestrutura; 14.5. Compartilhamento de \\ infraestrutura; 14.6. Exposição da marca.
}

Analisados os modais remuneratórios mais comuns das atividades públicas delegáveis a particulares (serviço público, intervenção no domínio econômico e poder de polícia), neste capítulo serão tratadas novas formas de custeio do agente privado que se põe a atuar em conjunto com a Administração.

Vale lembrar não ser exaustivo o rol abaixo apresentado, ou seja, sempre haverá a possibilidade de se extrair da interação público/privado utilidades econômicas exploráveis, no intuito de permitir a melhor relação custo $\mathrm{X}$ benefício do negócio, sempre 
pautado pelos princípios norteadores do agir da Administração Pública. Seguem, portanto, algumas hipóteses extraordinárias de remuneração, pois consectárias de situações atípicas.

\subsection{RECURSOS ADVINDOS DAS GARANTIAS NAS PARCERIAS PÚBLICO- PRIVADAS}

No capítulo 7 do presente estudo foram analisadas as formas de remuneração do particular parceiro do Poder Público. Apenas relembrando, a remuneração se dará através da cobrança de tarifas (concessão patrocinada), através da cobrança de tarifas e recebimento de contraprestação do Estado (concessão patrocinada) ou através do recebimento de contraprestação do Estado (concessão administrativa).

Neste capítulo uma nova forma de remuneração do parceiro privado é aventada. Qual o motivo de não ter sido apresentada naquela ocasião? Porque não é forma ordinária de remuneração nas PPPs. A execução das garantias (se existentes) pressupõe o descumprimento, por parte do parceiro público, do pactuado. Este deve custear a operação integralmente, no caso da concessão administrativa, ou parcialmente, na concessão patrocinada. Deixando de honrar com tal compromisso, surge ao particular o direito de pleitear sua remuneração, executando a garantia em favor dele concedida.

Nos termos do art. $8^{\circ}$ da Lei Federal $n^{\circ}$. 11.079/2004, as obrigações pecuniárias contraídas pela Administração Pública em contrato de parceria público-privada poderão ser garantidas mediante: vinculação de receitas, instituição ou utilização de fundos especiais previstos em lei, contratação de seguro-garantia com as companhias seguradoras que não sejam controladas pelo Poder Público, garantia prestada por organismos internacionais ou instituições financeiras que não sejam controladas pelo Poder Público, garantias prestadas por fundo garantidor ou empresa estatal criada para essa finalidade, dentre outros mecanismos admitidos em lei. 
Percebe-se ter a lei trazido a possibilidade de oferecimento de garantias robustas, dando ao particular a certeza de recebimento de seu crédito. Em trabalho específico sobre o tema tivemos a oportunidade de salientar ${ }^{169}$ :

É preciso um contexto sociopolítico-econômico favorável aos investimentos em infraestrutura pública, um ambiente de completo respeito à lei, de responsabilidade no gasto do dinheiro público, do fim do sentimento de impunidade - na ausência destes requisitos, as garantias tentam suprir tais lacunas!

Como em qualquer relação onde há um garante, seu acionamento é subsidiário; em outras palavras, só se executa a garantia se o devedor principal deixou de honrar com suas obrigações. Por isso tomamos a remuneração via garantia algo excepcional, extraordinário, presente apenas em situações de quebra de respeito ao contrato.

A garantia como forma de remuneração do particular executor de atividade pública nada mais é do que um instrumento jurídico capaz de permitir ao credor obter segurança de recebimento de seu crédito face ao devedor. As garantias podem ser reais e/ou pessoais. Logo, nem sempre será imediata a percepção dos valores a que faz jus. Se a garantia for pessoal, dependerá da vontade do garante em cumprir com seu encargo, sob pena de ser executado judicialmente. De outra feita, nas garantias reais deverá o credor excuti-la, ou seja, através de procedimento judicial efetuar a sua penhora e levar o bem a hasta pública, na tentativa de aliená-lo.

\subsection{A EXPECTATIVA DE RECEITA FUTURA}

\footnotetext{
${ }^{169}$ MIGUEL, Luiz Felipe Hadlich. As garantias nas parcerias público-privadas. Belo Horizonte: Fórum, 2011, p. 45
} 
O particular, ao formular sua proposta comercial num processo licitatório para concessão de dado serviço público, firma seu preço com base em diversos fatores, dentre eles, e principalmente, a demanda pelo serviço que irá prestar. Em regra uma demanda alta representa um potencial elevado de retorno financeiro. Uma demanda baixa, entretanto, traz incertezas à sustentabilidade do negócio.

Mas a mutabilidade das coisas permite, por vezes, sejam previstos ganhos futuros, a compensar possível prejuízo imediato. Tal perspectiva de lucro se apresenta como forma de remuneração do particular, que ingressou no certame de delegação da atividade não pelo presente, mas pelo futuro. Expliquemos com exemplos: é sabido que o governo federal, mesmo com grandes dificuldades e sensível atraso, está promovendo obras de grande vulto denominadas popularmente de "transposição do São Francisco". Espera-se, com o final de tal projeto, assegurar água para consumo humano a 12 milhões de habitantes de 390 municípios do agreste e do sertão dos estados de Pernambuco, Ceará, Paraíba e Rio Grande do Norte ${ }^{170}$. Alguns municípios da região beneficiada por tal projeto têm promovido concessões do serviço de esgotamento sanitário, tarifadas com base no volume de água utilizado. É certo que, com a chegada das águas da transposição, o consumo será exponencialmente maior, considerando hoje padecer a região com as secas que assolam o sofrido povo do sertão nordestino. Nestas licitações de concessão dos serviços de esgoto é razoável o oferecimento de propostas que, no cenário atual, não possibilitem a remuneração integral do executor do serviço (operação negativa); contudo, permitem assumirem tal ônus estimando o aumento da demanda num cenário já delineado de implantação do sistema acima noticiado.

A expectativa de receita futura é uma forma de remunerar o particular executor de atividade pública. A estrutura financeira de sua atuação permitirá ganhos

\footnotetext{
170 Informações colhidas do sítio eletrônico do Ministério da Integração Nacional: 〈http://www.mi.gov.br/pt/web/guest/o-que-e-o-projeto >. Acesso em 23 maio 2013.

O projeto de Integração do Rio São Francisco com Bacias Hidrográficas do Nordeste Setentrional é um empreendimento do Governo Federal, sob a reponsabilidade do Ministério da Integração Nacional. Tem objetivo de assegurar oferta de água para 12 milhões de habitantes de 390 municípios do Agreste e do Sertão dos estados de Pernambuco, Ceará, Paraíba e Rio Grande do Norte.

O Projeto São Francisco é hoje a maior obra de infraestrutura hídrica para usos múltiplos sendo executada diretamente pelo governo federal.

A previsão de conclusão do último trecho de obras é dezembro de 2015.
} 
futuros que comporão sua remuneração. Não estará sujeito à eventual reequilíbrio econômico-financeiro em favor da Administração, pois os dados utilizados como base a compor sua proposta são de todos conhecidos. O implemento de nova demanda era esperado e estimável. Fez o particular apenas postergar seu ganho, prevendo remunerar-se em momento futuro.

Pode-se visualizar o mesmo fenômeno nos serviços de telefonia celular. Não só a demanda aumenta, em razão da diminuição do valor dos aparelhos (lembremos, nos idos da década de 90 do século passado, um aparelho celular custava alguns milhares de dólares), mas também o tipo de uso se altera e se amplia. Hoje o volume de dados trafegados nas redes digitais (e-mails, acesso à internet, uso de redes sociais) supera o de voz. Vendem-se mais smartphones ${ }^{171}$ do que telefones, numa tendência de crescimento facilmente estimável.

Portanto, não decorrendo de algo fora do previsível, a expectativa de receita futura é um modal remuneratório do particular executor de atividade pública, em especial nas concessões de serviços públicos, nas quais os contratos perduram por muitos anos e, às vezes, por muitas décadas.

\subsection{GESTÃO DE CAPITAL}

Outra forma de remuneração do particular executor de atividade pública é a gestão do capital envolvido no negócio. Em cada delegação haverá montante de recurso que, se alavancado, trará retorno capaz de remunerar o agente executor da atividade.

\footnotetext{
${ }^{171}$ Smartphone é um telemóvel dotado de funcionalidades, em especial: conexão com redes de dados para acesso à internet e capacidade de sincronização dos dados do organizador com um computador pessoal.
} 
Gerir o capital nada mais é do que administrar os recursos, visando a obtenção do máximo de eficiência financeira na administração dos ativos. O capital é o recurso financeiro de qualquer empresa. Para compô-lo pode-se somar capital próprio (pertencente aos proprietários ou acionistas da empresa) com o capital de terceiros (empréstimos, debêntures, etc.).

$\mathrm{Na}$ implementação de uma atividade é necessária a instalação de infraestrutura afeta à sua execução. Por vezes cabe ao particular custear a construção do imprescindível à prestação do serviço concedido, por exemplo. Poderá fazê-lo com capital de terceiros, com uma eficiência econômica inferior àquela obtida quando atua com capital próprio (pois não estará assumindo o custo deste capital - juros).

Outro modal remuneratório ligado à gestão de capital é a administração do capital de giro. Ganhos de eficiência poderão ser atingidos com o controle de gastos, previsões de fluxo de caixa e administração de ativos circulantes (contas a receber e estoque).

Portanto, cumpre salientar ser capaz de gerar ganhos a gestão do capital relacionado à prestação de dada atividade, lhe trazendo eficiência econômica, ao final traduzida como forma de remuneração do agente privado.

\subsection{POTENCIAL ECONÔMICO GERADO PELA CONSTRUÇÃO DA INFRAESTRUTURA}

São também comuns os casos onde o particular, para prestar um serviço ou executar uma atividade, necessita inicialmente construir a infraestrutura necessária à implementação de seus objetivos. Isto ocorre, por exemplo, no serviço de telefonia móvel: 
para que o sistema opere é necessária a instalação de uma série de Estações Rádio Base $(E R B s)^{172}$, criando uma rede de comunicação entre as estações fixas e os terminais móveis.

Nem sempre a construção da infraestrutura afeta à atividade gera ganhos econômicos àqueles por ela influenciados. No caso da telefonia móvel não há uma valorização dos imóveis afetados diretamente pelas ERBs. O mesmo não ocorre, todavia, com os imóveis localizados no entorno dos estádios construídos ou reformados para a Copa do Mundo FIFA de 2014.

Alguns Estados da Federação utilizaram o modelo de parceria públicoprivada para possibilitar a reconstrução de seus estádios. Bahia, Ceará e Pernambuco ergueram suas arenas utilizando-se de concessões administrativas, delegando ao particular sua gestão por muitos anos, mesmo após o advento dos eventos esportivos que estão por vir.

Foram idealizadas alternativas de utilização do entorno dos estádios, visando a construção de hotéis, shoppings, anfiteatros, dentre outras áreas passíveis de comercialização. É sabido que o entorno de obras desta natureza sofre intensa valorização, especialmente nos primeiros anos após sua implementação ${ }^{173}$. Portanto, é possível se cogitar da remuneração do particular com a exploração dessa especulação imobiliária, ou com o acréscimo de potencial econômico no entorno dessa infraestrutura construída para a execução de uma atividade.

A experiência demonstra inclusive existir valorização de áreas onde há apenas projetos de construção de infraestrutura pública - o que dizer então quando a

\footnotetext{
${ }^{172}$ Estação Rádio Base (ERB) ou "Cell site" é a denominação dada em um sistema de telefonia celular para a Estação Fixa com que os terminais móveis se comunicam. A ERB está conectada a uma Central de Comutação e Controle (CCC) que tem interconexão com o serviço telefônico fixo comutado (STFC) e a outras CCCs, permitindo chamadas entre os terminais celulares e deles com os telefones fixos comuns.

${ }^{173}$ Matéria veiculada pelo sítio eletrônico de notícias G1: "Imóveis na área do $1^{\circ}$ estádio da copa a ficar pronto têm forte valorização". Disponível em: 〈http://g1.globo.com/ceara/noticia/2012/12/imoveis-na-areado-1-estadio-da-copa-ficar-pronto-tem-forte-valorizacao.html>. Acesso em 04 junho 2013.
} 
mesma está concluída! As cidades da baixada santista, por exemplo, verificaram forte valorização imobiliária durante a construção e especialmente após a conclusão da nova pista da Rodovia dos Imigrantes (que tornou o acesso àquela região mais rápido e seguro). Esse reflexo econômico, se explorado pelo particular participante da implementação da infraestrutura, pode ser tomado como fonte de sua remuneração, pois é algo sabido e esperado.

Não se trata de receita acessória, pois não decorre da atividade em si, mas sim de reflexo econômico ligado à implementação da infraestrutura atinente à atividade. Não é o caso do particular prestador do serviço de gestão prisional que, após construir o presídio, explora o espaço publicitário da parede externa de suas muralhas (receita acessória). É o caso do gestor de arena esportiva que constrói hotel na proximidade do equipamento de lazer, visando hospedar o público dos futuros eventos.

Imóveis próximos às estações do Metropolitano também sofrem os influxos da especulação imobiliária. O explorador do referido sistema de transporte (lembremos que na Capital Paulista há trecho da malha concedido à iniciativa privada) pode, eventualmente, se beneficiar da majoração do valor do metro quadrado das áreas atingidas pelas melhorias.

Enfim, a construção da infraestrutura necessária à prestação de dada atividade pode resultar em ganhos econômicos potencialmente exploráveis pelo próprio executor da obra, vindo a integrar um contexto arrecadatório e servindo de modal remuneratório à delegação de atividade pública.

\subsection{COMPARTILHAMENTO DE INFRAESTRUTURA}


Como apontado nos itens anteriores, algumas atividades, para serem desempenhadas, dependem da implementação de infraestrutura. Por vezes essa infraestrutura é disponibilizada pelo particular, que amortizará seus investimentos com a exploração da própria atividade, no prazo estabelecido pelo título que lhe a delegou.

Há casos em que a infraestrutura construída é capaz de suportar outros modais de atividade, além daquela inicialmente idealizada como objetivo da estrutura edificada. Como exemplo podemos citar o uso dos postes de energia elétrica como suporte físico do cabeamento das empresas de TV a cabo.

Surge então a possibilidade de exploração secundária da infraestrutura afeta a uma atividade, qual seja, o seu compartilhamento com outros executores de atividades públicas. Nas lições de Carlos Ari Sundfeld ${ }^{174}$ :

\begin{abstract}
Essa prática, que se convencionou denominar compartilhamento de infra-estrutura, não é nova. É comum que a estrutura construída e concebida para um determinado serviço público venha a ser utilizada como suporte de um outro. Assim ocorreu, por exemplo, com as estradas de ferro, cuja estrutura serviu de apoio para implantação das primeiras redes de telecomunicações, utilizadas para o telégrafo; com as rodovias, que emprestavam espaço para implantação de postes de transmissão de energia elétrica, de gasodutos, etc. Enfim, existem várias situações, facilmente encontráveis no cotidiano, que podem ser lembradas para confirmar quão comum é o uso compartilhado de infra-estrutura entre prestadores de serviços públicos.

A finalidade que norteia o compartilhamento de infra-estrutura é fácil perceber. Trata-se de mecanismo por intermédio do qual se potencializa a utilidade de uma determinada estrutura, que passa a atender, além da atividade principal para a qual foi concebida, outras atividades de utilidade pública.
\end{abstract}

Nestes termos, havendo ociosidade parcial, é tanto possível quanto indicado o seu compartilhamento, até mesmo para contribuir com a mitigação do impacto visual decorrente de sua implantação.

\footnotetext{
${ }^{174}$ SUNDFELD, Carlos Ari. Estudo jurídico sobre o preço de compartilhamento de infra-estrutura de energia elétrica. In: Revista eletrônica de direito administrativo econômico. Salvador, Instituto de Direito Público da Bahia. n. 4, nov.-dez. 2005, jan. 2006. Disponível em: 〈http://www.direitodoestado.com.br〉. Acesso em 09 novembro 2013.
} 
A Agência Nacional de Energia Elétrica (ANEEL), a Agência Nacional de Telecomunicações (ANATEL) e a Agência Nacional do Petróleo (ANP), reunidas, baixaram "regulamento conjunto para compartilhamento de infra-estrutura entre os setores de energia elétrica, telecomunicações e petróleo" ${ }^{175}$. Neste regulamento foram fixadas diretrizes para o compartilhamento da infraestrutura relacionada a cada um dos setores de atuação das referidas agências. Existem também regulamentos de cada uma delas dispondo acerca do compartilhamento de infraestrutura entre agentes de um mesmo setor.

Entende-se por infraestrutura, que poderão ser alvo de compartilhamento, nos termos do regulamento conjunto, as servidões administrativas, dutos, condutos, postes e torres, de propriedade, utilizados ou controlados, direta ou indiretamente, pelos agentes que exploram os serviços públicos de energia elétrica, os serviços de telecomunicações de interesse coletivo e os serviços de transporte dutoviário de petróleo, seus derivados e gás natural, bem como cabos metálicos, coaxiais e fibras ópticas não ativados.

O compartilhamento é o uso conjunto dessa infraestrutura, desde que exista capacidade excedente, ou seja, que haja parcela ociosa de seu potencial. Para ser possível o compartilhamento é necessário que sua implementação não acarrete perda de qualidade ou atente à segurança da atividade inicialmente executada.

Outrossim, o compartilhamento deve propiciar a otimização de recursos, reduzindo os custos operacionais, culminando com benefícios aos usuários dos serviços prestados.

O detentor da infraestrutura compartilhada fará jus a remuneração. Os preços a serem praticados podem ser livremente negociados pelos agentes, respeitadas a

\footnotetext{
175 Íntegra do regulamento disponível em: $<$ http://www.anatel.gov.br/Portal/verificaDocumentos/documento.asp?null\&filtro=1\&documentoPath=biblio teca/resolucao/1999/anexo_res_001_1999.pdf〉. Acesso em 05 junho 2013.
} 
isonomia e a livre competição. Os preços ajustados devem assegurar a remuneração do custo alocado à infraestrutura compartilhada e demais custos percebidos pelo detentor.

Portanto, é possível concluir que o compartilhamento de infraestrutura pode se apresentar como forma de remuneração do particular executor de atividade pública. $\mathrm{O}$ compartilhamento vem ao encontro dos ditames do princípio da eficiência, pois estar-se-á agregando utilidade à estrutura ociosa, tornando-a mais eficiente e, por consequência, menos custosa.

\subsection{EXPOSIÇÃO DA MARCA}

Este modal remuneratório já foi brevemente aventado no capítulo 8.8. deste estudo (referente à autorização contratual). Trata-se de uma permuta, onde o particular executa atividade pública em troca da exposição de sua marca.

Deverá existir proporcionalidade entre os encargos assumidos e as formas de divulgação da marca autorizadas. Parece-nos razoável, contudo, que o Poder Público avalie, a priori, o conteúdo do que será veiculado nos espaços publicitários.

Um exemplo que nos parece emblemático deste novel modelo de remuneração da atuação privada em atividades públicas é o das ciclofaixas. Iniciadas na cidade de São Paulo, hoje vários municípios já contam com iniciativas desta natureza. A capital paulista editou a Lei Municipal $n^{\circ}$. 14.266/2007, que dispõe sobre a criação do Sistema Cicloviário no município. Em seu art. $2^{\circ}$ consta que o sistema cicloviário será formado por ciclovias, ciclofaixas, faixas compartilhadas e rotas operacionais de ciclismo. Já o art. $6^{\circ}$, por sua vez, dispõe que a ciclofaixa consistirá numa faixa exclusiva destinada à 
circulação de bicicletas, delimitada por sinalização específica, utilizando parte da pista ou da calçada.

Com o advento da lei o Executivo Municipal se pôs a buscar alternativas à consecução dos objetivos nela traçados. Impossibilitado de arcar com os altos custos de implementação das ciclofaixas, que envolve desde a delimitação do percurso no solo, sinalização vertical, demarcação de faixas para orientação dos motoristas, disponibilização de pessoal para colocação e retirada dos marcos (cones) que determinam seu traçado, agentes para monitoramento dos usuários, dentre outras coisas, chegou-se a uma parceria com a Bradesco Seguros e Previdência, que se incumbiu de organizar, aos domingos e feriados, a montagem e manutenção das ciclofaixas, em troca da impressão, nos cones de demarcação, bem como nos uniformes dos agentes e monitores de orientação, de sua marca, logotipo e slogan.

Iniciativa semelhante a do Banco Itaú, ao estampar seu logotipo nos cestinhos das bicicletas (que, por sinal, são da cor de sua marca) por ele disponibilizadas ao uso de qualquer do povo, em "pontos" de liberação eletrônica localizados em algumas ruas da capital paulista.

Por fim, vale trazer à baila o exemplo dos enfeites de natal dos principais monumentos públicos das grandes cidades. O particular se encarrega de, seguindo padrões pré-estabelecidos pela Administração, decorar os pontos turísticos e monumentos de maior importância do município, em troca da afixação de algumas placas com seu nome. 


\section{QUESTÕES FINAIS}

15.1. Ganhos decorrentes de alterações factuais no curso do contrato; 15.2. Procedimento de manifestação de interesse: 15.2.1. Possibilidade de desenhos financeiros ainda não concebidos; 15.3. A remuneração das gratuidades.

Antes de partirmos à análise específica da problemática que escora a presente tese, vale tratarmos de algumas questões finais relacionadas com o tema da remuneração do particular executor de atividade pública. Alterações factuais podem modificar o contexto econômico da atuação privada, implicando em ganhos não estimados. Outrossim, um procedimento um tanto quanto recente permite a idealização de formas remuneratórias inovadoras, fruto da criatividade da iniciativa privada. 
Como já apontado em diversas passagens deste trabalho, as avenças que delegam a execução de atividade pública a particular apresentam, por vezes, longos prazos de duração. Não raras são as concessões de serviços por mais de 30 (trinta) anos. Nesse longo período muitas coisas podem se alterar, impactando diretamente o fluxo financeiro do particular executor de determinada atividade.

Imaginemos, a título de exemplo, as concessões dos serviços de saneamento. Para a prestação da atividade o concessionário utiliza-se de equipamentos diversos, dentre eles bombas d’água de alta capacidade, fabricadas na Alemanha. A Europa passa por forte crise econômica, acusando forte retração em seu consumo e baixa sensível de preços. Diante deste cenário, as fabricantes alemãs de bombas d'água resolvem investir nos mercados emergentes, instalando no Brasil parques industriais para fabricação de seus equipamentos.

Na hipótese singelamente descrita acima é de se supor que o concessionário irá se beneficiar de preços melhores na compra dos insumos necessários à prestação de seus serviços. Provavelmente a bomba d’água antes adquirida da Alemanha será agora comprada por menor preço (não incidência de imposto de importação, menor custo com frete, etc.). Percebe-se, portanto, que uma alteração no campo macroeconômico pode trazer reflexos à execução da atividade do concessionário, culminando em economia e, ao final, em majoração de seus resultados financeiros.

Mudanças cambiais, desoneração de impostos, incentivos a determinados setores - enfim, uma infinidade de alterações factuais pode culminar com ganhos (ou perdas), aprisionáveis pela iniciativa privada.

Talvez o leitor esteja a questionar: caso alterações da natureza acima descrita ocorram, não estaríamos diante de desequilíbrio econômico-financeiro, a ensejar 
seu restabelecimento? Entendemos que não, pois tais ocorrências encontram-se no campo da álea ordinária. É um fato incerto quanto ao momento de sua constatação. Todavia, tratase de alteração passível de ocorrer em qualquer empreendimento, em qualquer lugar do globo. Não está atrelada a atos da Administração (nem como parte da relação, nem como ente no exercício de seu poder extroverso), mas sim a condições macroeconômicas nas quais a Administração em nada pode influenciar.

Desta forma, os ganhos decorrentes dessas alterações podem ser incorporados ao fluxo financeiro do particular, integrando sua remuneração.

\subsection{PROCEDIMENTO DE MANIFESTAÇÃO DE INTERESSE}

O Procedimento de Manifestação de Interesse (PMI), regulamentado na esfera federal pelo Decreto $n^{\circ}$. 5.977/2006, figura como um novo instrumento de efetivação de parcerias entre Administração Pública e iniciativa privada.

Incluso na sistemática das PPPs (apresentadas hoje como importante forma de possibilitar ao Estado a atração do capital privado), o PMI visa a exploração da criatividade da iniciativa privada, em prol da criação e identificação de "novos negócios" extraíveis da estrutura e do patrimônio do Estado.

Nos termos do decreto supracitado, caberá à Administração Pública definir as PPPs prioritárias - sendo sobre essas prioridades que as manifestações privadas deverão se ater. O particular poderá, então, estruturar uma PPP, produzindo projetos e estudos, levando-os ao conhecimento do Poder Público. Este, por sua vez, poderá aproveitá-los, ou não, em futura licitação para delegação da atividade fruto da análise privada. 
Deverá o particular modelar o negócio em todos os seus aspectos: técnico, jurídico, econômico, político, ambiental, etc. Caso a Administração entenda ser coerente o modelo apresentado, o idealizador do negócio fará jus ao ressarcimento de suas despesas. Busca o PMI, portanto, ser instrumento capaz de fomentar o uso das PPPs, estimulando investimentos privados em infraestrutura, solucionando os graves problemas dos gargalos estruturais que ainda freiam o desenvolvimento da economia nacional.

\subsubsection{Possibilidade de desenhos financeiros ainda não concebidos}

A ideia central do PMI é explorar a criatividade e a eficiência do mundo empresarial. Ao Poder Público caberá iniciar o procedimento. No caso concreto, é mais coerente serem os estudos realizados pela iniciativa privada do que por servidores públicos ou consultores contratados para este desiderato.

Não é de se estranhar não dispor a Administração de corpo técnico capaz de estruturar determinados tipos de projetos. Isso porque alguns empreendimentos apresentam complexidade técnica deveras específica, cujo know-how está restrito a poucas empresas de setores determinados, ou dependem do trabalho de equipe multidisciplinar, muitas vezes impossível de ser composta tão somente por servidores públicos.

Ademais, vale lembrar ser a iniciativa privada, costumeiramente, mais eficiente do que o Poder Público, pois não carrega em seu bojo o ônus de suportar a máquina burocrática a ele inerente. Por essas razões, a Administração deve apenas e tão somente apresentar os contornos da ideia, fazendo constar claramente quais os objetivos a serem alcançados e suas expectativas com o procedimento. Deve deixar claro também os métodos que serão utilizados na avaliação dos eventuais projetos. 
A autorização para elaboração desses projetos, estudos, levantamentos ou investigações jamais será conferida em caráter de exclusividade. A ideia é exatamente atrair vários players ao procedimento, em busca do modelo mais interessante aos interesses tutelados pelo Estado.

Neste cenário de ampla liberdade de atuação o particular poderá idealizar projetos com estruturas financeiras inovadoras. Poderá criar modais remuneratórios que busquem fontes de receitas ainda desconhecidas. A iniciativa privada poderá estruturar negócios atrelados à atividade pretendida, visando a extração do potencial econômico máximo do empreendimento. Enfim, poderá usar de sua criatividade para conceber algo totalmente revolucionário.

Aí reside a importância do PMI. Não passa o Estado, com isso, a ser mero coadjuvante do processo de desenvolvimento econômico, mas sim verdadeiro articulador das políticas públicas que visam a obtenção do real e completo atendimento dos seus fins.

\subsection{A REMUNERAÇÃO DAS GRATUIDADES}

Por vezes as atividades delegadas à execução privada apresentam parcelas de beneficiários que não irão contribuir diretamente para seu custeio. A eleição de "grupos" que não deverão colaborar com a sustentabilidade financeira da operação da atividade não é prerrogativa do prestador, mas sim do ente que a outorgou. Os critérios para atribuição do discrímen devem se pautar pela tentativa de minoração da exclusão social dos grupos favorecidos.

Quando as atividades gratuitas (como saúde e educação pública, por exemplo) são prestadas diretamente pelo Estado, são os recursos públicos, derivados dos 
tributos arrecadados, que fazem frente às despesas de sua disponibilização. Todavia, nos casos das atividades executadas por pessoas de direito privado, a gratuidade toca o tema do equilíbrio econômico-financeiro da relação entabulada entre Poder Público e particular.

Nesta esteira, deve o Poder Público apresentar, ab initio, quais os grupos de potenciais usuários da atividade que serão beneficiados pela benesse da gratuidade de sua fruição. Assim, ao formular sua proposta de atuação, o particular irá considerá-los e verificar, dentro do modelo remuneratório previsto para a delegação, se é viável sua operação.

Especificamente com relação aos serviços públicos, esfera de atuação estatal onde a questão da gratuidade normalmente se coloca, deverá o particular considerar, na formulação de sua proposta comercial, que parte dos usuários não irá contribuir. Em outras palavras, deverá onerar os pagantes, para custear os não pagantes. Agindo assim, estará equilibrada a relação entabulada com o Poder Público.

O problema surge quando o Concedente aumenta o universo de beneficiários da gratuidade no curso de uma concessão, por exemplo, sem que nenhuma contrapartida seja oferecida ao particular prestador do serviço. Aqui novamente a questão da necessária manutenção da equação econômico-financeira aflora (remetemos o leitor ao item 4.3. do presente trabalho). Em estudo específico sobre o tema, Manoel Messias Peixinho $^{176}$ fez questão de anotar:

Se, porém, houver necessidade de alteração das cláusulas de execução do contrato (clauses contractualles), a lei exige que o poder concedente negocie com o concessionário a manutenção do equilíbrio financeiro do contrato (equilibre financier du contract). As cláusulas exorbitantes, que autorizam prerrogativas de alterar os contratos administrativos unilateralmente, não abrangem as cláusulas financeiras, mas somente as cláusulas regulamentares (clauses réglementaires) pertinentes à execução do contrato.

(...)

\footnotetext{
${ }^{176}$ PEIXINHO, Manoel Messias. Serviços públicos delegados, fonte de custeio e direitos fundamentais. In: Revista da faculdade de direito de Campos. Ano VIII, n. 10, jun. 2007.
} 
Nessa linha de raciocínio - reafirme-se o poder concedente não pode alterar unilateralmente as cláusulas financeiras -, os concessionários não são obrigados a cumprir o novo encargo fora do rol de obrigações previsto no contrato. Na hipótese de o Estado instituir por ato normativo serviço público gratuito, para ser prestado pelo delegatário, deverá haver concomitante e obrigatoriamente ao ato, previsão da correspondente fonte de custeio, seja para majorar a tarifa paga pelo usuário, seja para celebrar acordo que viabilize a compensação remuneratória.

A única hipótese que nos parece aceitável, de alteração unilateral do contrato para inclusão de gratuidade a parcela de potenciais usuários, é a decorrente das benesses já trazidas pela Constituição Federal. Desta forma, caso a Administração, por um lapso, tenha se esquecido de colocar no edital e decorrente contrato que o transporte para o idoso seria gratuito, não pode o concessionário pleitear a devida compensação pela realização da atividade. 


\section{EM BUSCA DE UM REGIME JURÍDICO \\ REMUNERATÓRIO}

16.1. Traços comuns a toda e qualquer execução de atividade pública por particular; 16.2. Aspectos imprescindíveis ao sistema remuneratório; 16.3. Regra geral de remuneração; 16.4. A identidade de um sistema.

Chegamos, neste capítulo, ao ponto central da discussão desta tese: existe um regime jurídico remuneratório do particular prestador de atividade pública? Buscamos, inicialmente, definir o que é remuneração, quem são os particulares e o que são atividades públicas. Dividindo em 3 (três) grandes blocos, analisamos as diversas possibilidades remuneratórias em cada uma das atividades públicas identificadas como possíveis de serem executadas por particulares: serviços públicos, exploração de atividade econômica e poder de polícia. Por fim, trouxemos alguns modais mais atuais de remuneração, bem como aspectos recentes que impactam as relações entre o público e o privado. 
Cumpre agora, com base nas reflexões trazidas nos capítulos anteriores, apresentarmos resposta à indagação formulada no início da tese. Eis o resultado de nossas meditações:

\subsection{TRAÇOS COMUNS A TODA E QUALQUER EXECUÇÃO DE ATIVIDADE PÚBLICA POR PARTICULAR}

Três atividades típicas da Administração Pública foram consideradas, de início, passíveis de delegação à execução, total ou parcial, pela iniciativa privada. Os serviços públicos já não encontram, na doutrina e na jurisprudência atual, maiores restrições à sua delegabilidade. O mesmo não ocorre com a exploração de atividade econômica pelo Estado, transferida ao particular por via transversa, agindo nesta esfera de atuação estatal como parte da estrutura que efetivamente intervém no mercado. Por fim, a execução de atos de polícia por particular ainda encontra resistência na doutrina e na jurisprudência, sendo coerente, à luz do ordenamento atual, visualizarmos parcelas delegáveis desta atividade.

Cada um desses grandes "blocos" de atuação estatal delegável engloba uma infinidade de atuações, uma diversidade de atividades das mais variadas naturezas. $\mathrm{Na}$ prestação de serviços públicos, por exemplo, pode o Estado atribuir ao particular o direito de explorar o serviço de transporte público (voltado, em essência, a atender os interesses dos usuários deste serviço), ou conceder a exploração da atividade de gestão de centro de processamento de dados (concentrando a atuação privada no atendimento dos interesses da própria Administração). Na exploração de atividade econômica, por sua vez, o particular pode atuar como partícipe do processo de intervenção do Estado na ordem econômica, ou como verdadeiro protagonista do fomento. Por fim, no poder de polícia o particular poderá executar meros atos materiais preparatórios necessários à completude da atuação estatal ou participar, quase que exclusivamente, do processo de formação do ato. 
Mesmo diante dessa considerável diversidade de naturezas e condições de participação, nos parece possível identificar alguns elementos comuns em toda e qualquer execução de atividade pública por particular.

Em qualquer delas o particular só pode atuar mediante justo título, aqui não entendido nos moldes do direito civil, mas sim como o título, genericamente considerado, hábil a conferir direitos (contrato, termo, pacto, acordo, participação acionária, etc.). Em outras palavras, deve haver um ato formal, escrito, permitindo a atuação privada em campo até então restrito ao Poder Público. Não nos parece possível a entrega de atividade pública à execução privada por ato verbal, pois restaria prejudicado seu controle, inerente à atuação estatal.

Lembremos que as "parcerias" entre Estado e iniciativa privada são alvo de análise do Poder Legislativo (por intermédio das Cortes de Contas), da Controladoria (onde houver - autocontrole), do Ministério Público, bem como de qualquer do povo (ação popular). Esse controle pressupõe a formalização dos atos, permitindo sua avaliação e averiguação mesmo após sua efetiva concretização.

Outro aspecto comum em toda e qualquer execução de atividade pública por particular é a existência de uma agenda de direitos e obrigações, estabelecida pelo instrumento que dá origem à parceria. Deverá existir um regramento mínimo dessa atuação privada, permitindo às partes cobrarem-se mutuamente acerca do cumprimento de suas obrigações, mantendo-se equilibrada a relação então pactuada.

Por fim, deve a Administração Pública fiscalizar toda e qualquer atuação do particular na realização de atividades públicas. A delegação da atividade transfere o direito de executar função do Estado. Portanto, dada a natureza pública da atividade (que 
permanece existindo), cabe à iniciativa privada cumprir os desideratos do Poder Público, sob seu controle e fiscalização.

\subsection{ASPECTOS IMPRESCINDÍVEIS AO SISTEMA REMUNERATÓRIO}

O sistema remuneratório das parcerias firmadas entre Estado e iniciativa privada também é bastante amplo. Como já tratado nos capítulos anteriores, existem casos onde a remuneração advém exclusivamente de tarifas cobradas dos usuários da atividade colocada à disposição pelo particular. Em outras situações os recursos originam-se dos cofres públicos. É possível também haver uma mescla dessas duas alternativas, além da exploração de externalidades da própria atividade.

Mesmo diante desta infinita gama de possibilidades nos parece que alguns aspectos são imprescindíveis, em qualquer sistema remuneratório, visando a manutenção da atividade e a regularidade de sua execução.

O primeiro aspecto refere-se à existência de um fator de atualização dos valores a que faz jus o particular. A inflação é o aumento contínuo de preços de bens, produtos e serviços em uma determinada região durante um período. Ao mesmo tempo em que os produtos se tornam mais caros, o poder de compra da moeda diminui. De acordo com informações constantes do sítio eletrônico do Governo Federal ${ }^{177}$, as décadas de 60 e 70 do século passado simbolizaram o início do desequilíbrio econômico no Brasil. Naquele período os índices de inflação chegavam a aproximadamente 40\% ao ano. Entre 1990 e 1994 a média anual de inflação alcançou 764\%. A partir de 1994 (com a criação do Plano Real), o país deu seus primeiros passos rumo à estabilidade econômica. Hoje vivemos um momento de inflação controlada através da definição da taxa básica de juros da economia

$\overline{177}$ <http://www.brasil.gov.br/sobre/economia/mercado-financeiro/inflacao>. Acesso em 17 junho 2013. 
(Selic) pelo Banco Central, importante instrumento de atuação estatal para controle da inflação.

Apesar da competente atuação do Banco Central nos últimos anos, não é desarrazoado pensar na possibilidade de aumento da inflação, prejudicando diretamente a remuneração do particular prestador de atividade pública, caso não exista algum mecanismo de correção desses valores. Desta forma, imprescindível que as parcerias firmadas entre Estado e iniciativa privada tragam mecanismos de atualização monetária (ou correção monetária), ou seja, um ajuste periódico dos valores, com base na inflação de um período, visando compensar a perda de valor da moeda.

Ademais, a variação dos preços dos insumos necessários à prestação da atividade também dá azo a eventuais "descolamentos" dos valores das tarifas vis-à-vis os custos operacionais do particular, impondo o reajuste de sua remuneração. Não se trata de aumento do valor da remuneração, mas simples readequação. Celso Antônio Bandeira de Mello ${ }^{178}$, diferenciando a correção monetária do reajuste (muito mais relacionado a particularidades da atividade específica), foi feliz ao apontar:

Averbe-se que correção monetária é a simples variação numérica expressiva de um mesmo valor que permanece inalterado e tão-somente passa a ser expresso por números diferentes. Assim: o número tal expressa na data " $B$ " a mesma grandeza que o número qual expressava na data "A". A grandeza representada é constante, o número que a representa é que varia. Ou seja, na data "A", a uma dada prestação (x) corresponde uma expressão em moeda y, a qual, para persistir exprimindo este mesmo valor, na data "B", deveria alterar-se. Pode-se figurar a situação da seguinte maneira. Na data " $A$ " $x=y$; na data " $B$ " $x=y$ '; pois y em "A" é o mesmo que y'em "B".

(...)

$\mathrm{O}$ reajuste, do qual se trata mais detidamente em tópico próprio, embora consista, tal como a correção monetária, em fórmula adrede concebida para preservar o conteúdo econômicofinanceiro do ajuste de modo fluido, simples e pacífico, tem compostura e objeto completamente diferente dela. $\mathrm{O}$ que se pretende com ele, como seu próprio nome indica, é alterar o valor a ser pago em função da variação de valor que determinava a composição do preço. Expliquemo-nos.

Como a equação estabelecida entre as partes é uma relação de equivalência entre prestações recíprocas, fica entendido que ao custo de uma prestação (x) - que se compõe dos encargos econômicos por ela implicados e a margem de lucro remuneratório ali embutida correspondem os pagamentos (y) que a acobertam. Esta relação de igualdade ideal, convencionada, deve ser mantida. Assim, se os custos dos insumos necessários à prestação (x)

${ }^{178}$ Op. Cit., pp. 605/607. 
sofrem elevações constantes - como é rotineiro entre nós -, os pagamentos (y) têm de incrementar-se na mesma proporção, sem o quê a igualdade denominada "equação econômicofinanceira" deixa de existir, decompõe-se.

A obrigatoriedade de correção e reajuste de preços deriva do dever de manutenção da equação econômico-financeira dos contratos administrativos. O que consideramos imprescindível é a existência de um fator de atualização, bem como fórmulas de reajuste, a serem aplicados em intervalos pré-definidos. Vale lembrar que, na remota hipótese de haver deflação (processo inverso à inflação) ou variação negativa dos preços dos insumos, também devem ser revistos os valores.

Outro aspecto imprescindível é o respeito da Administração para com o pactuado. Aliás, é essencial que os ajustes do Poder Público sejam respeitados. Tal afirmação pode parecer desnecessária, mas a experiência como advogado, lidando diuturnamente com contratos administrativos, nos leva a tratar como imprescindível à integridade e continuidade da atividade pública delegada a obrigação de cumprir o acordado.

Uma parceria só pode ser assim definida enquanto coexistir um interesse comum. Este interesse está resguardado pelo cumprimento recíproco das obrigações pactuadas. Ao descumprir o acordo o Poder Público fere de morte a parceria, quebrando o equilíbrio da relação e tornando instável a continuidade da atividade. Atenta contra a segurança jurídica, necessária à manutenção do particular como parceiro da Administração.

Tratando da correção monetária e do respeito aos contratos, merece destaque julgado do C. Superior Tribunal de Justiça:

REsp 599851 / RJ

RECURSO ESPECIAL 2003/0186538-1

Ministro TEORI ALBINO ZAVASCKI

Órgão Julgador: T1 - PRIMEIRA TURMA

Data do Julgamento: 26/04/2005

Ementa 
ADMINISTRATIVO. CONTRATO. PAGAMENTO EM ATRASO. CORREÇÃO MONETÁRIA. INCIDÊNCIA.

1. A submissão dos contratos administrativos às cláusulas nele estabelecidas, como prevê o art. 44 do Decreto-Lei 2.300/86, não exime a Administração de pagar com correção monetária as parcelas em atraso, ainda que omisso a respeito o contrato. O descumprimento da avença, no caso, se deu pelo atraso do pagamento, e não pela incidência da correção monetária, que nada mais é do que a recomposição do valor real da moeda.

2. Recurso especial a que se nega provimento.

Portanto, imprescindível à sistemática remuneratória de qualquer delegação de atividade pública à execução por particular a existência de pleno respeito ao pacto originário da parceria e que, mesmo no silêncio do instrumento acerca da correção monetária e do reajuste tarifário, seja estabelecido um critério de readequação do numerário que representará, na data do pagamento, o montante devido ao particular.

\subsection{REGRA GERAL DE REMUNERAÇÃO}

Não obstante a diversidade de atividades titularizadas pelo Estado, a infinidade de modais remuneratórios das suas delegações e a complexidade dos desenhos financeiros dos acordos entre Poder Público e iniciativa privada, é possível vislumbrar uma regra geral de remuneração, aplicável a todo e qualquer caso.

Nem sempre o particular executor de atividade pública visa o lucro. É possível vir em auxílio do Estado com o simples intuito de suplementá-lo naquilo onde sua atuação for falha. Não é uma regra do sistema remuneratório, portanto, a existência de benefício econômico.

De outra feita, também não se pode conceber parceria que não permita ao particular, ao menos, cobrir os seus custos. O leitor talvez pergunte: mesmo o particular assim querendo, não pode operar no prejuízo? A resposta, a nosso ver, é negativa. A 
questão tangencia o tema da inexequibilidade das propostas, como adiante restará demonstrado.

O fundamental, nesta seara, não é exatamente o valor fixado pelo particular como adequado à sua remuneração, mesmo aceitando o resultado negativo. O que importa, ao final, é saber se é possível ao particular executar aquilo a que se propôs.

A remuneração inadequada induz ao não cumprimento do avençado, desatendendo o essencial objetivo da delegação da atividade. A Administração que permite seja determinada atividade por ela titularizada (de interesse público, portanto) executada por particular insuficientemente remunerado não obterá o resultado almejado. A prática tem nos mostrado que oferecer preços irrisórios em certames levados a efeito pelo Estado resultam em baixa qualidade na prestação dos seus objetos, ausência de pagamentos de tributos e pleitos rotineiros de reequilíbrio econômico-financeiro dos contratos.

Uma das maiores autoridades sobre o assunto, Marçal Justen Filho ${ }^{179}$ parece não comungar da mesma opinião:

Discorda-se do entendimento de que todas as hipóteses de inexequibilidade comportam tratamento jurídico idêntico. Ao contrário, deve impor-se uma diferenciação fundamental, destinada a averiguar se a proposta pode ou não ser executada pelo licitante, ainda que seu valor seja deficitário. A questão fundamental não reside no valor da proposta, por mais ínfimo que o seja - o problema é a impossibilidade de o licitante executar aquilo que ofertou.

A formulação desse juízo envolve uma avaliação da capacidade patrimonial do licitante. Se ele dispuser de recursos suficientes e resolver incorrer em prejuízo, essa é uma decisão empresarial privada. Não cabe à Administração a tarefa de fiscalização da lucratividade empresarial privada. Sob esse ângulo, chega a ser paradoxal a recusa da Administração em receber proposta excessivamente vantajosa.

Enfim, seria inconstitucional o dispositivo legal que vedasse a benemerência em prol do Estado. Impor ao Estado o dever de rejeitar proposta gratuita é contrário à Constituição. Se um particular dispuser-se a aplicar seus recursos para auxiliar o Estado, auferindo remuneração irrisória, isso não pode ser vedado por dispositivo infraconstitucional. Cabe admitir, portanto, que o Estado perceba vantagens e benefícios dos particulares.

${ }^{179}$ JUSTEN FILHO, Marçal. Comentários à lei de licitações e contratos administrativos. 12. Ed. São Paulo: Dialética, 2008, pp. 601/602. 
Mais ainda, um particular plenamente capaz pode dispor de seus bens, inclusive para lançar-se em empreitadas econômicas duvidosas. Poderá assumir riscos, de que derivarão prejuízos. Não é cabível que o Estado assuma, ao longo da licitação, uma função similar à de curatela dos licitantes. Se um particular comprometer excessivamente seu patrimônio, deverá arcar com o insucesso correspondente.

Ousamos discordar do pensamento acima exposto. A preocupação da Administração ao vedar que um particular se lance em empreitada deficitária não está em protegê-lo, mas sim em preservar a atividade. Uma vez delegada, sua assunção posterior, caso não esteja sendo executada a contento, é demorada e onerosa. Por força da natureza das atividades titularizadas pelo Estado, temerário que se permita a delineação de cenário prejudicial à sua continuidade. Ademais, a intenção benemerente do particular pode ser resolvida por meio de doações, não sendo a prestação de atividades públicas com resultados negativos o modo mais adequado e seguro do Poder Público aceitar vantagens e benefícios oferecidos pela iniciativa privada.

Curioso é que o mesmo jurista supra citado, em trecho seguinte de sua obra, assim destaca:

\begin{abstract}
Admitir generalizadamente a validade de propostas de valor insuficiente pode significar um incentivo a práticas reprováveis. O licitante vencedor procurará alternativas para obter resultado econômico satisfatório. Isso envolverá a redução da qualidade da prestação, a ausência de pagamento dos tributos e encargos devidos, a formulação de pleitos perante a Administração e assim por diante.

Usualmente, a contratação avençada por valor insuficiente acarretará a elevação dos custos administrativos de gerenciamento do contrato. Caberá manter grande vigilância quando à qualidade e perfeição do objeto executado e litígios contínuos com o particular, sempre interessado em obter uma solução que propicie a reestruturação da contratação. Logo, as vantagens obtidas pela Administração poderão ser meramente aparentes. No final, a Administração obterá ou um objeto de qualidade inferior ou se deparará com problemas muito sérios no pertinente à execução do contrato ${ }^{180}$.
\end{abstract}

Também não se pode perder de vista um problema secundário, mas também atinente ao tema. Admitir a possibilidade de o particular executar atividade pública às suas expensas é permitir a concorrência desleal. Nos termos da Constituição Federal, deve o Estado agir para coibir abusos do poder econômico e práticas anticompetitivas. Cumpre ao

${ }^{180}$ Op. Cit., pp. 602/603. 
Poder Público, portanto, evitar que em suas próprias ações práticas desta natureza venham a ocorrer.

Portanto, temos como regra geral de remuneração do particular executor de atividade pública a viabilidade econômica da estrutura financeira que lhe dará suporte.

Em determinados tipos de ajustes, entretanto, poderá o particular custear parcela da atividade, desde que efetivamente comprove a saúde financeira de sua proposta de atuação. Tal afirmação pode até parecer contraditória, quando em cotejo com o anteriormente exposto. Mas a questão da atuação do terceiro setor, notadamente, permite eventual operação negativa, se analisado seu custeio apenas por recursos públicos, mas nunca deficitária dentro da proposta inicial, composta também por recursos advindos da iniciativa privada.

Em outras palavras: na composição de custos do particular deve existir, no mínimo, um equilíbrio entre receitas e despesas. As receitas podem ter origens diversas. Não será legítima a atuação privada em atividade pública, contudo, quando as despesas suplantarem, no "marco zero" da parceria, as receitas estimadas.

Não pode o Estado, ademais, descurar da fiscalização. Deverá estar atento a todos os elementos da parceria, em especial à qualidade da execução da atividade. Dificuldades financeiras do particular costumam resultar em queda dos padrões de qualidade. Nestes casos, deverá agir prontamente, sempre visando a continuidade da atividade, tutelando o interesse público, que é sua função primordial.

\subsection{A IDENTIDADE DE UM SISTEMA}


Nos itens anteriores do presente capítulo procuramos demonstrar que, não obstante a diversidade de modais remuneratórios concebíveis como forma de possibilitar a atuação da iniciativa privada em atividades da Administração Pública, é viável a identificação de traços comuns que culminam numa regra geral de remuneração.

Todavia, a questão colocada à prova na presente tese não está albergada pelas constatações acima explicitadas. Nosso objetivo, ao idealizar o tema do trabalho, era buscar um "regime jurídico remuneratório do executor de atividade pública". Para tanto, elegemos como via de perquirição a análise dos grupos de atividades da Administração, em tese, delegáveis à execução por particulares.

Percebemos, com o desenvolvimento do trabalho, que não obstante alguns aspectos serem imprescindíveis em toda e qualquer delegação de atividade pública à execução privada, estes eram insuficientes para delimitar um "regime".

Para se determinar a existência de um "regime" seria necessário um conjunto de elementos, concretos ou abstratos, sempre presentes. Seria necessário que a remuneração se estruturasse com base em unidades inter-relacionáveis, ou seja, mesmo compondo-se de elementos independentes, logicamente resultassem em um conjunto de ideias que fundamentassem aquele "grupo" de atuações semelhantes.

Mas não é o que ocorre! Os pontos comuns, identificados nos itens deste capítulo, são suficientes para nos permitir identificar uma estrutura básica, que deve estar presente em toda e qualquer parceria entre Estado e iniciativa privada.

Entretanto, a busca pelo "regime jurídico remuneratório" restou prejudicada ao nos depararmos com situações antagônicas, não nos permitindo identificar um conjunto mínimo de elementos comuns, apenas alguns princípios e diretrizes básicas. 
E nem poderia ser outra a conclusão. A diversidade de atuações do Poder Público impõe um ritmo frenético de mudanças e adaptações, surgindo a cada dia uma nova Administração Pública, com novos objetivos e novos instrumentos de atuação. Idealizar um "regime" seria o mesmo que dar à luz um natimorto - algo concebido e já ultrapassado -, incapaz de manter-se adequado com o decurso do tempo.

Aliás, regime único, como o que pretendíamos delimitar, é algo cada dia mais raro, não só no direito administrativo, mas em todos os ramos da ciência jurídica. A complexidade da vida em sociedade, exponencialmente majorada com a globalização das economias e culturas, vem impondo a necessidade de criação de soluções específicas, afastando o operador do direito de fórmulas pré-concebidas e de lugares comuns. 


\section{CONCLUSÃO}

É chegado o momento de apresentarmos as conclusões obtidas das discussões e reflexões lançadas nas linhas precedentes. O trabalho elaborado é fruto de uma mescla de estudos teóricos e experiências profissionais; talvez por isso o leitor consiga identificar nas conclusões adiante expostas aspectos acadêmicos e pragmáticos.

O estudo de temas jurídicos, a nosso ver, parte de uma premissa: $a$ experiência jurídica é uma experiência normativa. Quem melhor analisou a questão foi Norberto Bobbio ${ }^{181}$, em sua "Teoria geral do direito":

Nossa vida desenvolve-se em um mundo de normas. Acreditamos ser livres, mas na verdade estamos envoltos numa densa rede de regras de conduta, que desde o nascimento até a morte dirigem nossas ações nesta ou naquela direção.

(...)

Podemos dizer desde já, ainda que em termos genéricos, que o direito constitui uma parte notável, e talvez também a parte mais visível, da nossa experiência normativa. E por isso um

${ }^{181}$ BOBBIO, Norberto. Teoria geral do direito. São Paulo: Martins Fontes, 2007, pp. 3/4. 
dos primeiros resultados do estudo do direito é de nos tornar conscientes da importância do "normativo" em nossa existência individual e social.

A tese ora apresentada é uma análise de um fenômeno jurídico atinente a um ramo da ciência jurídica. Nesta esteira, o pressuposto de análise da temática foi o de observância às normas regulamentadoras da matéria. A legislação brasileira que rege o assunto foi a linha condutora do exame do tema. Em alguns momentos a norma deu lugar à doutrina e à jurisprudência, especificamente nas situações onde sua vagueza não permitia a obtenção de soluções práticas adequadas.

Todo trabalho científico deve seguir um caminho, no intuito de se chegar a um destino. Contudo, nem sempre o destino alcançado é aquele inicialmente idealizado pelo pesquisador. A estrada é tortuosa, nem sempre se segue por onde se espera. E o resultado, por vezes, surpreende. É o que aconteceu na presente tese!

Antes de partimos especificamente às conclusões, cumpre apontar ainda outra particularidade do problema discutido no estudo: trata-se de tema deveras dinâmico. Diferente de outros assuntos relacionados ao direito administrativo, as alterações legislativas são intensas; outrossim, a doutrina mais atual se desprega de conceitos clássicos, dando à matéria uma nova roupagem e um novo brilho.

Vejamos, portanto, a quais conclusões chegamos:

1) Ao Estado cumpre a execução de uma grande quantidade de atividades. Dessas atividades, apenas algumas podem ser delegadas à execução por particular. São elas: serviços públicos, intervenção do Estado no domínio econômico e social e aspectos do poder de polícia; 
2) Nas hipóteses onde a delegação é possível, deve o Estado prover condições do particular se remunerar, visando a continuidade e atualidade da atividade;

3) A tarifa, fonte tradicional de receita do particular executor de atividade pública, tem perdido espaço para modais remuneratórios mais sofisticados e eficientes;

4) A remuneração nem sempre advém de fonte única. São possíveis modelagens de delegações em que diversos modais remuneratórios coexistem;

5) Com o advento das parcerias público-privadas tornou-se possível a remuneração do particular exclusivamente por recursos públicos (não caracterizáveis como subsídio ou subvenção);

6) É possível se vislumbrar a participação do particular como agente imediato da exploração direta de atividade econômica pelo Estado, quando integrante da sociedade de economia mista criada para tal desiderato;

7) Boa parte dos elementos que compõem o poder de polícia podem ser delegados à execução privada. A remuneração do particular que exerce poder de polícia é legítima, mas não será feita através da cobrança de taxas;

8) A criatividade e competência da iniciativa privada em modelar novos negócios podem ser aproveitadas pela Administração através da promoção de PMIs (Procedimentos de Manifestação de Interesse);

9) É pressuposto da relação público/privado a manutenção das condições iniciais da avença; 
10) Os pactos da Administração devem ser flexíveis, permitindo adaptações às mudanças que acometem relações de longo prazo;

11) A diversidade de atuações administrativas permite a concepção de uma infinidade de modais remuneratórios.

O desenvolvimento e o progresso do Estado brasileiro estão intimamente ligados à interação "público/privado". A incapacidade estatal de investir impõe ao Poder Público a busca pelo capital privado. O Brasil é uma economia em ampla expansão, freada apenas pela deficitária infraestrutura pública e elevada carga tributária. Novos modelos de "negócios públicos" podem retirar das mãos do Estado o dever de custear a construção dessa infraestrutura insuficiente e antiquada, culminando com a redução da carga tributária e a alavancagem do desenvolvimento nacional.

Cumprirá ao Estado, então, ser o grande gestor e idealizador dessa "reforma", ficando incumbido de arquitetar as atuações privadas. Não mais atuará como executor, mas sim como fiscal da implementação da infraestrutura necessária ao desenvolvimento do país.

Como dito alhures, a diversidade de atuações administrativas e de modais remuneratórios não nos permitiu identificar um "regime remuneratório do particular prestador de atividade pública". Existem, sim, alguns aspectos comuns em toda e qualquer delegação de funções da Administração à iniciativa privada. Todavia, insuficientes para caracterizar um regime, assim entendido como o conjunto de imposições, jurídicas e fiscais, que determinam a maneira de reger uma determinada situação. 
Essas eram as conclusões que puderam ser extraídas das reflexões lançadas no trabalho. A dinâmica da evolução administrativa continuará a nos brindar com novas soluções, impondo a necessidade de revisão das ideias aqui expostas num curto espaço de tempo. Que o texto sirva de provocação aos pensamentos do leitor. Se vossa inquietude for maior do que vossa concordância, teremos atingido nosso objetivo.

"Onde está a felicidade? No amor ou na indiferença? $\mathrm{Na}$ obediência ou no poder? No orgulho ou na humildade? $\mathrm{Na}$ investigação ou na fé? $\mathrm{Na}$ celebridade ou no esquecimento? $\mathrm{Na}$ nudez ou na prosperidade? $\mathrm{Na}$ ambição ou no sacrifício? A meu ver, a felicidade está na doçura do bem, distribuído sem ideia de remuneração. $\mathrm{Ou}$, por outra, sob uma fórmula mais precisa, a nossa felicidade consiste no sentimento da felicidade alheia, generosamente criada por um ato nosso." 


\section{BIBLIOGRAFIA}

ALMEIDA, Fernando Dias Menezes de. Contrato administrativo. São Paulo: Quartier Latin, 2012.

ALMEIDA, Guilherme Henrique de La Roque. Controle das transferências financeiras da União. Belo Horizonte: Fórum, 2008.

AMARAL, Antônio Carlos Cintra do. Concessão de serviços públicos: novas tendências. São Paulo: Quartier Latin, 2012.

ARAGÃO, Alexandre Santos de. Curso de direito administrativo. Rio de Janeiro: Forense, 2012. 
As parcerias público-privadas - PPP's no direito positivo brasileiro. In: Revista eletrônica de direito administrativo econômico. Salvador, Instituto de Direito Público da Bahia, n. 2, maio-jun.-jul., 2005. Disponível em: <http://www.direitodoestado.com.br>. Acesso em 08 abril 2013. . Direito dos serviços públicos. Rio de Janeiro: Forense, 2007.

BINENBOJM, Gustavo. As parcerias público-privadas (PPPs) e a constituição. In: Revista eletrônica de direito administrativo econômico. Salvador, Instituto de Direito Público da Bahia, n. 2, maio-jun.-jul., 2005. Disponível em:〈http://www.direitodoestado.com.br〉. Acesso em 03 abril 2013.

BOBBIO, Norberto. Teoria geral do direito. São Paulo: Martins Fontes, 2007.

BONELLI, Claudia Elena; IAZZETTA, Rodnei. Contratos de parceria público privada: PPP no Brasil. In: CASTRO, José Augusto Dias de; TIMM, Luciano Benetti (Orgs.). Estudos sobre as parcerias público-privadas. São Paulo: IOB Thomson, 2006.

CÂMARA, Jacintho Arruda. Tarifa nas concessões. São Paulo: Malheiros, 2009.

CARDOZO, José Eduardo Martins. As empresas públicas e as sociedades de economia mista e o dever de realizar concursos públicos no direito brasileiro. Jus Navigandi, Teresina, ano 2, n. 17, 10 ago. 1997. Disponível em: <www.jus.com.br/revista/texto/386. Acesso em 14 maio 2013.

CARRAZZA, Roque Antonio. Curso de direito constitucional tributário. 19. Ed. São Paulo: Malheiros, 2004. 
CARVAlHO, Paulo de Barros. Curso de direito tributário. 13. Ed. São Paulo: Saraiva, 2000.

CICERO, Nidia Karina. Servicios publicos - control y proteccion. Buenos Aires: Ediciones Ciudad Argentina, 1996.

DALlARI, Adilson Abreu. Aspectos jurídicos da licitação. 7. Ed. São Paulo: Saraiva, 2007.

DI PIETRO, Maria Sylvia Zanella. Direito administrativo. 22. Ed. São Paulo: Atlas, 2009. . Parcerias na administração pública. 6. Ed. São Paulo: Atlas, 2008. Contratos de gestão. Contratualização do controle administrativo sobre a administração indireta e sobre as organizações sociais. Disponível no sítio eletrônico do Centro de Estudos da Procuradoria Geral do Estado de São Paulo: $<$ http://www.pge.sp.gov.br/centrodeestudos/revistaspge/revista2/artigo9.htm>. Acesso em 23 abril 2013.

Privatização e o novo exercício de funções públicas por particulares. In: MOREIRA NETO, Diogo de Figueiredo (Coord.). Uma avaliação das tendências contemporâneas do direito administrativo. Rio de Janeiro: Renovar, 2003.

DROMI, José Roberto. Manual de derecho administrativo. Tomo 1. Buenos Aires: Editorial Astrea, 1987.

DUARTE, Leonardo Avelino. Diferenças constitucionais entre as taxas, tarifas e preços públicos em sentido estrito - uma proposta de diferenciação. Disponível em: <http://www.fatonotorio.com.br/artigos/ver/21/diferencas-constitucionais-entre-as-taxastarifas-e-precos-publicos-em-sentido-estrito-uma-proposta-de-diferenciacao >. Acesso em 19 março 2013. 
EVANS, Guillermo E. Fanelli. Las subvenciones en las concesiones de obras y de servicios públicos. In: CASSAGNE, Juan Carlos (Coord.). Derecho administrativo, obra coletiva en homenaje al Profesor Miguel S. Marienhoff. Buenos Aires: Ed. Abeledo-Perrot, 1998.

FERREIRA, Luiz Tarcísio Teixeira. Parcerias público-privadas, aspectos constitucionais. Belo Horizonte: Fórum, 2006.

FORTINI, Cristiana. O princípio da legalidade e o emprego da franquia pela administração pública brasileira. In: Revista eletrônica de direito administrativo eletrônico. Salvador, Instituto de Direito Público da Bahia, nº. 6, mai./jun./jul. de 2006. Disponível em: $<$ www.direitodoestado.com/revista/REDAE-6-MAIO-2006-

CRISTIANA\%20FORTINI.pdf>. Acesso em 04 maio 2013.

FURTADO, Lucas Rocha. Curso de direito administrativo. Belo Horizonte: Fórum, 2007.

GASPARINI, Diógenes. Direito administrativo. 6. Ed. São Paulo: Saraiva, 2001.

GRECCO, Carlos Manuel. Potestad tarifaria, control estatal y tutela del usuario. In: MUÑOZ, Guillermo Andrés; GRECCO, Carlos Manuel. Fragmentos y testimonios del derecho administrativo. Buenos Aires: Ad-Hoc, 1999.

GUIMARÃES, Fernando Vernalha. As parcerias público-privadas e a transferência de atividades de suporte ao poder de polícia: em especial, a questão dos contratos de gestão privada de serviços em estabelecimentos prisionais. In: SUNDFELD, Carlos Ari (Coord.). Parcerias público-privadas. São Paulo: Malheiros, 2005. 
As receitas alternativas nas concessões de serviços públicos no direito brasileiro. In: Revista de direito público da economia. Belo Horizonte: Fórum, vol. 6, $\mathrm{n}^{\circ}$. 21 , janeiro 2008.

HOUAISS, Antônio. Grande dicionário Houaiss da língua portuguesa. Disponível em: $<$ http://houaiss.uol.com.br/busca?palavra=subs\%25C3\%25ADdio $>$. Acesso em 10 abril 2013.

JUSTEN FILHO, Marçal. Curso de direito administrativo. 8. Ed. Belo Horizonte: Fórum, 2012.

Comentários à lei de licitações e contratos administrativos. 12. Ed. São Paulo: Dialética, 2008.

LIMA, Carolina Caiado. O convênio administrativo colaborativo para transferência de recursos públicas a entidades privadas sem fins lucrativos como instrumento dos mecanismos diretos de fomento público. Dissertação de Mestrado. Faculdade de Direito da Universidade de São Paulo, 2010.

MACHADO, Maurício Castilho. A tarifa nas concessões de serviço público. Jus Navigandi, Teresina, ano 14, $\mathrm{n}^{\circ}$. 2.293, 11 out. 2009. Disponível em: <www.jus.com.br/revista/texto/13673 >. Acesso em 6 maio 2013.

MARQUES NETO, Floriano de Azevedo. Bens públicos. Função social e exploração econômica. O regime jurídico das utilidades públicas. Belo Horizonte: Fórum, 2009.

As parcerias público-privadas no saneamento ambiental. In: Revista eletrônica de direito administrativo econômico. Salvador, Instituto de Direito Público da Bahia. n. 2, maio-jun.-jul., 2005. Disponível em: 〈http://www.direitodoestado.com.br>. Acesso em 08 abril 2013. 
- Entrevista concedida ao sítio eletrônico Migalhas. Disponível em: <http://www.direitopublico.com.br/noticias2.php?id=1835>. Acesso em 09 abril 2013.

MEDAUAR, Odete. O direito administrativo em evolução. 2. Ed. São Paulo: RT, 2003. . Direito administrativo moderno. 12. Ed. São Paulo: RT, 2008.

A figura da concessão. In: MEDAUAR, Odete (Coord.). Concessão de serviço público. São Paulo: RT, 1995.

MELO JR., Regnoberto Marques de. Da natureza jurídica dos emolumentos notariais e registrais. Jus Navigandi, Teresina, ano 10, n. 591, 19 fev. 2005. Disponível em: <http://jus.com.br/revista/texto/6313>. Acesso em 18 julho 2013.

MELLO, Celso Antônio Bandeira de. Curso de direito administrativo. 21. Ed. São Paulo: Malheiros, 2006.

As parcerias público-privadas e a observância dos princípios constitucionais.

Revista do Tribunal de Contas do Estado de Minas Gerais, Belo Horizonte, TCEMG, v. 56, n. 3, jul./set. 2005 .

Las cláusulas de reajuste de precios en los contratos administrativos. In: CASSAGNE, Juan Carlos (Coord.). Derecho administrativo, obra coletiva en homenaje al Profesor Miguel S. Marienhoff. Buenos Aires: Ed. Abeledo-Perrot, 1998.

MIGUEL, Luiz Felipe Hadlich. Limites à delegação do poder de polícia. In: MEDAUAR, Odete; SCHIRATO, Vitor Rhein (Coords.). Belo Horizonte: Fórum, 2013. (No prelo) As relações entre o público e o privado nas parcerias público-privadas. In: MEDAUAR, Odete; SCHIRATO, Vitor Rhein (Coords.). Belo Horizonte: Fórum, 2014. (Inédito) 
. Silêncio administrativo - o "não ato". In: MEDAUAR, Odete; SCHIRATO, Vitor Rhein (Coords.). Os caminhos do ato administrativo. São Paulo: RT, 2011.

. As garantias nas parcerias público-privadas. Belo Horizonte: Fórum, 2011.

MONTEIRO, Vera. Concessão. São Paulo: Malheiros, 2010.

MOREIRA, Egon Bockmann. Direito das concessões de serviço público - inteligência da lei 8.987/1995 (parte geral). São Paulo: Malheiros, 2010.

MUÑOZ, Guillermo Andrés. Contratos de la administración. In: MUÑOZ, Guillermo Andrés; GRECCO, Carlos Manuel. Fragmentos y testimonios del derecho administrativo. Buenos Aires: Ad-Hoc, 1999.

OLBERTZ, Karlin. A regulamentação da concessão urbanística no Município de São Paulo. In: Informativo Justen, Pereira, Oliveira e Talamini. Curitiba, n. 25, mar. 2009. Disponível em: $\langle$ http://www.justen.com.br//informativo.php?I=pt\&informativo=25\&artigo=878 $>$. Acesso em 09 novembro 2013.

OLIVEIRA, Gustavo Henrique Justino de. Estado contratual, direito ao desenvolvimento e parceria público-privada. In: TALAMINI, Eduardo; JUSTEN, Mônica Spezia (Coords.). Parcerias público-privadas, um enfoque multidisciplinar. São Paulo: RT, 2005.

OLIVEIRA, Rafael Carvalho Rezende. Administração pública, concessões e terceiro setor. 2. Ed. Rio de Janeiro: Lumen Juris, 2011. 
OLIVEIRA, Regis Fernandes de. Curso de direito financeiro. 2. Ed. São Paulo: RT, 2008.

PALAZZO, José Luis; SESÍN, Domingo Juan; LEMBEYE, Víctor Armando Rolón. La trasformación del estado - tendencias actuales - innovaciones em el derecho italiano y europeo. Buenos Aires: Ediciones Depalma, 1992.

PEIXINHO, Manoel Messias. Serviços públicos delegados, fonte de custeio e direitos fundamentais. In: Revista da faculdade de direito de Campos. Ano VIII, n. 10, jun. 2007.

PINTO JUNIOR, Mário Engler. Parceria público-privada: antigas e novas modalidades contratuais. In: PAVANI, Sérgio Augusto Zampol; ANDRADE, Rogério Emilio (Coords.). Parcerias público-privadas. São Paulo: MP, 2006.

PORTO NETO, Benedicto. Licitação para contratação de parceria público-privada. In: SUNDFELD, Carlos Ari (Coord.). Parcerias público-privadas. São Paulo: Malheiros, 2005.

RIBEIRO, Luís Paulo Aliende. A regulação da função pública notarial e de registro. Tese de Doutorado. Faculdade de Direito da Universidade de São Paulo, 2008.

RIBEIRO, Mauricio Portugal; PRADO, Lucas Navarro. Comentários à lei de PPP: parceria público-privada - fundamentos econômico-jurídicos. São Paulo: Malheiros, 2007.

ROCHA, Carmén Lúcia Antunes. Estudos sobre concessão e permissão de serviço público no direito brasileiro. São Paulo: Saraiva, 1996. 
ROCHA, Sílvio Luís Ferreira da. Terceiro setor. 2. Ed. São Paulo: Malheiros, 2006.

SANTIAGO, Emerson. Concorrência perfeita. InfoEscola - Economia. Disponível em: <http://www.infoescola.com/economia/concorrencia-perfeita/>. Acesso em 10 maio 2013.

SCHIRATO, Vitor Rhein. Livre iniciativa nos serviços públicos. Belo Horizonte: Fórum, 2012.

SCHOENMAKER, Janaina. Controle das parcerias entre o estado e o terceiro setor pelos tribunais de contas. Belo Horizonte: Fórum, 2011.

SCHWIND, Rafael Wallbach. Remuneração do concessionário: concessões comuns $e$ parcerias público-privadas. Belo Horizonte: Fórum, 2010.

SILVA, Patrícia Pinheiro. Terceirização nos serviços públicos. In: Revista do Tribunal Superior do Trabalho, v. 77, n. 1, jan./mar. 2011. Disponível em: <http://aplicacao.tst.jus.br/dspace/bitstream/handle/1939/22336/005_silvapatricia.pdf?sequ ence=1>. Acesso em 09 maio 2013.

SUNDFELD, Carlos Ari; SOUZA, Rodrigo Pagani de; PINTO, Henrique Motta. Empresas semiestatais. Revista de direito público da economia - RDPE. Belo Horizonte, ano 9, n. 36, out./dez. 2011.

- Estudo jurídico sobre o preço de compartilhamento de infra-estrutura de energia elétrica. In: Revista eletrônica de direito administrativo econômico. Salvador, Instituto de Direito Público da Bahia. n. 4, nov.-dez. 2005, jan. 2006. Disponível em: <http://www.direitodoestado.com.br >. Acesso em 09 novembro 2013. 
TÁCITO, Caio. O poder de polícia e seus limites. Direito administrativo. 1975.

WALD, Arnoldo; MORAES, Luíza Rangel de; WALD, Alexandre de Mendonça. $O$ direito de parceria e a lei de concessões. 2. Ed. São Paulo: Saraiva, 2004.

ZANCHIM, Kleber Luiz. Concessão urbanística e serviço público. Disponível em: 〈http://www.migalhas.com.br/mig_amanhecidas.aspx?cod1=81406>. Acesso em 09 novembro 2013. 
